UNIVERSIDADE DE SÃO PAULO

FACULDADE DE FILOSOFIA, LETRAS E CIÊNCIAS HUMANAS DEPARTAMENTO DE LETRAS CLÁSSICAS E VERNÁCULAS MESTRADO PROFISSIONAL EM REDE NACIONAL

LILIANE BATTISTIN

O poema no ensino fundamental II: jogos lúdicos, leitura e produção textual

VERSÃO CORRIGIDA

SÃO PAULO

2018 
LILIANE BATTISTIN

\title{
O poema no ensino fundamental II: jogos lúdicos, leitura e produção textual
}

\author{
Dissertação apresentada ao Programa de \\ Pós-graduação Mestrado Profissional em \\ Rede Nacional PROFLETRAS, vinculado ao \\ Departamento de Letras Clássicas e \\ Vernáculas, da Faculdade de Filosofia, Letras \\ e Ciências Humanas da Universidade de São \\ Paulo, como parte dos requisitos para a \\ obtenção do título de Mestre em Letras. \\ Orientadora: Profa. Dra. Norma Seltzer \\ Goldstein.
}

VERSÃO CORRIGIDA

De acordo 18/04/2018

SÃO PAULO

2018 
Nome: BATTISTIN, Liliane

Título: O poema no ensino fundamental II: jogos lúdicos, leitura e produção textual

Dissertação apresentada ao Programa de Pós-graduação Mestrado Profissional em Rede Nacional PROFLETRAS, vinculado ao Departamento de Letras Clássicas e Vernáculas, da Faculdade de Filosofia, Letras e Ciências Humanas da Universidade de São Paulo, como parte dos requisitos para a obtenção do título de Mestre em Letras.

Aprovado em:

Banca Examinadora

Prof. Dr. Instituição:

Julgamento: Assinatura:

Prof. Dr. Instituição:

Julgamento: Assinatura:

Prof. Dr. Instituição:

Julgamento: Assinatura: 
Dedico este trabalho ao meu pai Francisco (in memoriam), a minha mãe Elizabete, ao meu esposo Ricardo e ao meu filho Ricardinho com muito amor e carinho. 


\section{AGRADECIMENTOS}

À CAPES, cujo apoio institucional tornou possível este trabalho.

À professora doutora Norma Seltzer Goldstein que orientou e me elucidou sempre que necessário.

Aos membros da Banca de Qualificação que contribuíram para o desenvolvimento do trabalho.

À professora doutora Zilda Gaspar de Oliveira Aquino, Coordenadora do Programa de Pós-graduação - Mestrado Profissional em Rede Nacional da Universidade de São Paulo, em 2016 e 2017, pela atenção com que nos orientou.

Às professoras doutoras Elis de Almeida Cardoso Caretta e Maria Inês Batista Campos, Coordenadoras atuais do Programa de Pós-graduação - Mestrado Profissional em Rede Nacional da Universidade de São Paulo.

Aos professores do Programa de Pós-graduação - Mestrado Profissional em Rede Nacional da Universidade de São Paulo, com os quais aprendi muito.

Aos colegas do PROFLETRAS, com quem compartilhei descobertas e aprendizagens. 
A escola enche o menino de matemática, de geografia, de linguagem, sem via de regra, fazê-lo através da poesia da matemática, da geografia, da linguagem. A escola não repara em seu ser poético, não o atende em sua capacidade de viver poeticamente o conhecimento e o mundo. O que eu pediria à escola, se não me faltassem luzes pedagógicas, é considerar a poesia como primeira visão direta das coisas e, depois, como veículo de informação prática e teórica, preservando em cada aluno o fundo mágico, lúdico, intuitivo e criativo, que se identifica basicamente-se com a sensibilidade poética.

Carlos Drummond de Andrade, 1974 


\section{RESUMO}

BATTISTIN, Liliane. O poema no ensino fundamental II: jogos lúdicos, leitura e produção textual. Dissertação (mestrado). Faculdade de Filosofia, Letras e Ciências Humanas, Universidade de São Paulo, 2018.

O desenvolvimento da competência leitora e escritora nem sempre ocorre na escola de modo pleno. Desse modo, os níveis de letramento, no ensino fundamental II, avançam lentamente. $O$ estudante nem sempre consegue utilizar os recursos linguísticos para escrever textos e/ou interpretá-los. A presente pesquisa justifica-se pela intenção de sugerir atividades didáticas que de fato promovam 0 desenvolvimento das competências em leitura e escrita. Assim, foi estudado o letramento mediante as propostas que empregam os gêneros textuais como estratégia didática no ensino de língua materna. Por meio da elaboração e aplicação de atividades, o objetivo é verificar se a leitura e comentários orais decorrentes, bem como as atividades de escrita, auxiliam o estudante (sexto ano) a confeccionar poemas. A hipótese estabelecida é a de que uma proposta fundamentada na leitura (silenciosa, compartilhada) e nas rodas de conversa corrobora com a apropriação das características do gênero poema e, por conseguinte, viabiliza indivíduos agentes, que conseguem escrever textos com autonomia. A metodologia desta pesquisa organizou-se em cinco etapas: percurso histórico dos processos de aprendizagem em Língua Portuguesa, apresentação do gênero poema e suas especificidades, aplicação da proposta didática, coleta de dados (textos escritos pelos alunos - individual e coletivamente) e, por fim, análise qualitativa dos dados. Fundamentou esta pesquisa os conceitos de letramento (Antunes, 2009; Kleiman, 1998, 2007; Rojo 2004, 2005; Soares 2002, 2004), os conceitos de dialogismo no texto literário (Bakthin, 2016; Fiorin, 2006), os conceitos do gênero poema (Bosi, 2000; Goldstein, 1999, 2006, 2007; Martins, 2008), os conceitos de agência (Bazerman, 2006), os conceitos de autoria (Possenti, 2007; Tfouni, 2015) e os conceitos de éthos (Amoussy, 2011; Discini, 2014). Concluiu-se que uma proposta didática bem fundamentada conduz o estudante a apropriar-se das características do gênero e a escrever poemas com traços de autoria.

Palavras-chave: Poema. Letramento. Atividade lúdica como estratégia. 


\begin{abstract}
ABSTRATIC
BATTISTIN, Liliane. The poem at Middle School in Brazil: playful learning material, reading and text writing. Dissertação (mestrado). Faculdade de Filosofia, Letras e Ciências Humanas, Universidade de São Paulo, 2018.

The development of the reading and writing competences not always happen fully at school. Thus, levels of literacy at Middle School in Brazil, progress slowly. The student not always can use the linguistic resources to write texts and/or decode them. This research justifies itself through the intention of suggesting teaching activities, that, indeed, promote development of competences in reading and writing. Therefore, it has been studied the literacy through proposals that apply the textual genres as didactic strategies in the mother tongue's teaching. By the means of elaborating and applying activities, the aim is to verify if the reading and resulting oral comments, as well writing activities, aid the student ( $6^{\text {th }}$ grade) to write poems. The established hypothesis is that a proposal based on the reading (silent, shared) and on chat groups support the appropriation of the poem features and consequently facilitates agent individuals who can write texts with autonomy. The methodology of this research is organized in five steps: historical path of the Portuguese language learning process, presentation of the poem genre and its specificities, an application of the didactic proposed, gathering of data (texts written by students - individually and collectively), and, finally, the quality analysis of data. Concepts of literacy based this research (Antunes, 2009; Kleiman, 1998, 2007; Rojo 2004, 2005; Soares 2002, 2004), concepts of dialogism in literary text (Bakthin, 2016; Fiorin, 2006), concepts of poem (Bosi, 2000; Goldstein, 1999, 2007; Martins, 2008), concepts of agency (Bazerman, 2006), concepts of authorship (Possenti, 2007; Tfouni, 2015) and concepts of ethos (Amoussy, 2011; Discini, 2014). To conclude, a didactic proposal well based conducts the student to appropriate oneself of the genre features and to write poems with traces of authorship.
\end{abstract}

Keywords: Poem. Literacy. Playful learning as strategy. 


\section{LISTA DE ILUSTRAÇÕES}

Gráfico 1 - O que é poema para você? (Antes de iniciar a proposta didática)............82 Gráfico 2 - O que é poema para você? (Após a aplicação da proposta didática) $\quad . .85$ Gráfico 3 - Características do gênero conforme respostas (Após a aplicação da proposta didática) 


\section{LISTA DE QUADROS}

Quadro 1 - Esquematização da sequência didática 36 


\section{LISTA DE SIGLAS E ABREVIAÇÕES}

$\begin{array}{ll}\text { ENEM } & \text { Exame Nacional do Ensino Médio } \\ \text { INEP } & \text { Instituto Nacional de Estudos e Pesquisas Educacionais } \\ & \text { Anísio Teixeira } \\ \text { MEC } & \text { Ministério da Educação } \\ \text { OCSCS } & \text { Orientações Curriculares de São Caetano do Sul } \\ \text { OLP } & \text { Olimpíada de Língua Portuguesa } \\ \text { PCESP } & \text { Proposta Curricular do Estado de São Paulo } \\ \text { PCNs } & \text { Parâmetros Curriculares Nacionais } \\ \text { PCN+ } & \text { Orientações Educacionais Complementares aos } \\ & \text { Parâmetros Curriculares Nacionais } \\ \text { PCNEM } & \text { Parâmetros Curriculares Nacionais do Ensino Médio } \\ \text { SD } & \text { Sequência (s) Didática (s) }\end{array}$




\section{SUMÁRIO}

PERCURSO PROFISSIONAL DA AUTORA 13

INTRODUÇÃO 16

1 DIVERSIDADE TEXTUAL NA FORMAÇÃO LEITORA E ESCRITORA - UM PERCURSO SÓCIO HISTÓRICO

1.1 LEITURA E PRODUÇÃO DE ESCRITA: DO ENSINO TRADICIONAL ÀS

PERSPECTIVAS CONTEMPORÂNEAS

1.2 AS PROPOSTAS CURRICULARES DE ENSINO DE LÍNGUA PORTUGUESA

1.3 O GÊNERO LITERÁRIO NOS DOCUMENTOS OFICIAIS 32

1.4 SEQUÊNCIA DIDÁTICA: APRENDIZAGEM DA LÍNGUA POR MEIO DO USO DOS GÊNEROS TEXTUAIS

2 LITERATURA NA ESCOLA

2.1 CARÁTER ESSENCIALMENTE DIALÓGICO DO TEXTO LITERÁRIO ...........38

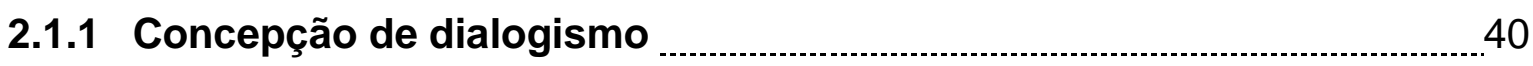

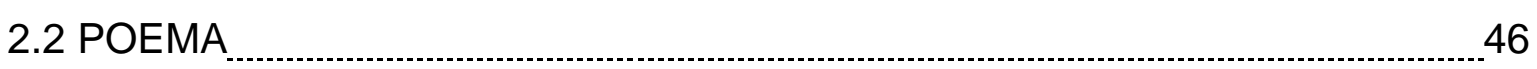

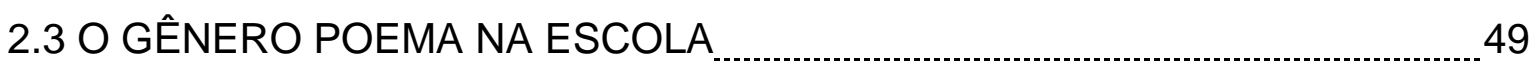

3 APRESENTAÇÃO DA PROPOSTA DIDÁTICA APLICADA EM AULA .............53

3.1 OBJETIVOS

3.2METODOLOGIA

3.3 PERFIL DA SALA DE AULA - CONTEXTO DA APLICAÇÃO DA PROPOSTA DIDÁTICA

3.4O CARÁTER LÚDICO NA PROPOSTA DIDÁTICA O CARÁTER LÚDICO NA

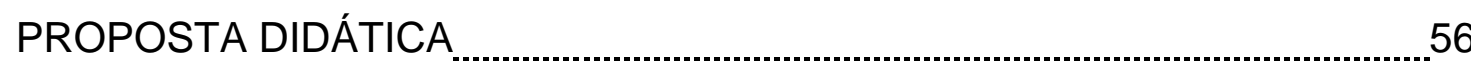

3.5DAS ATIVIDADES PROPOSTAS E DA PROPOSTA DE JOLIBERT _..............57

3.6RELATO DAS AULAS E ATIVIDADES DESENVOLVIDAS AO LONGO DA

PROPOSTA DIDÁTICA

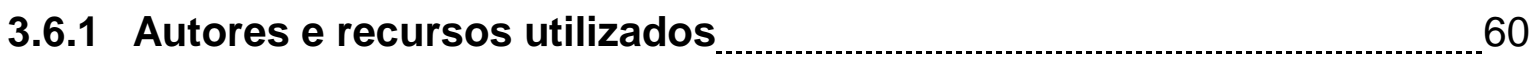

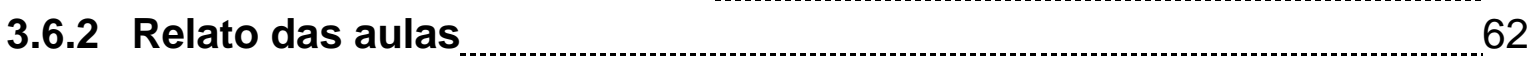

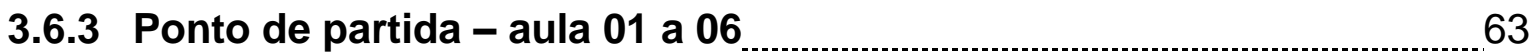

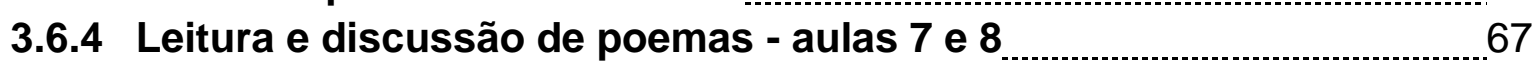

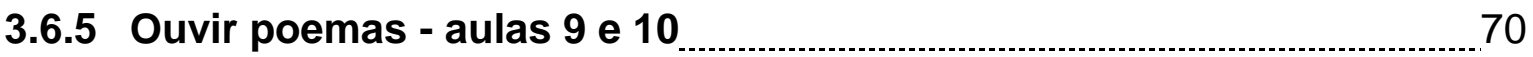


3.6.6 Versos regulares - aula 11

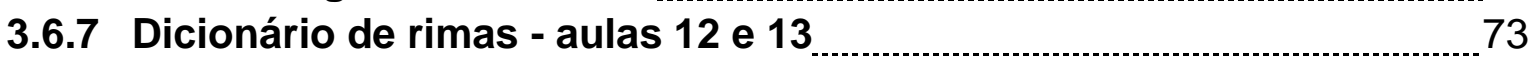

3.6.8 Apresentação de poetas mirins - aula 14 ……................................. 74

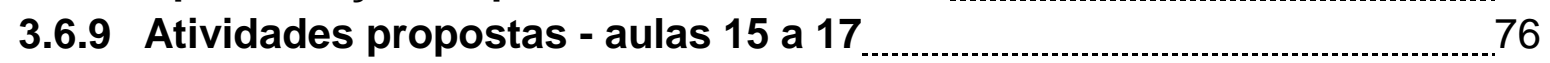

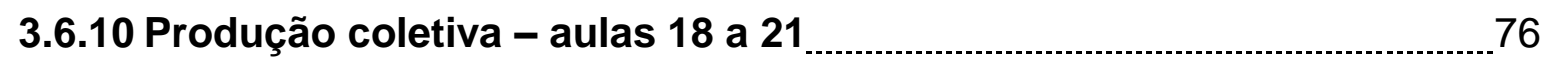

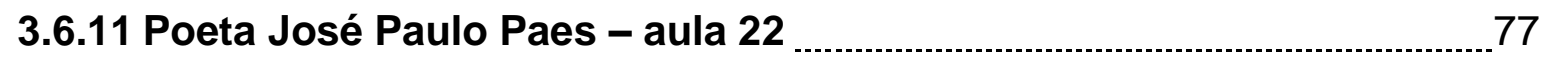

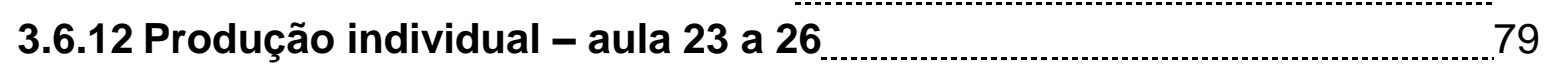

4 ANÁLISE DO CORPUS

4.10 QUE É POEMA PARA VOCÊ? .................................................................. 82

4.2ÉTHOS E ESTILO NAS ATIVIDADES DE ESCRITA

4.2.1 As produções coletivas

4.2.2 Traços de autoria nas produções individuais $\ldots \ldots \ldots$

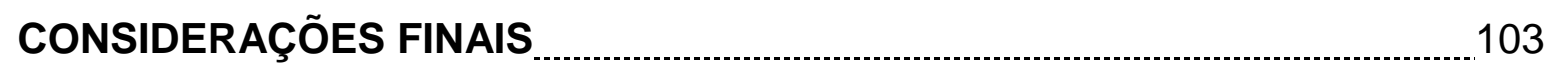

REFERÊNCIAS

ANEXO A - TERMO DE CONSENTIMENTO LIVRE E ESCLARECIDO _............114

ANEXO B - TEXTOS UTILIZADOS NAS ATIVIDADES _.................................... 115

ANEXO C - PRODUÇÕES DE ESCRITA - DECORRER DA PROPOSTA ...........120

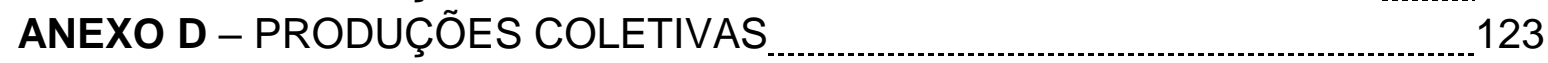

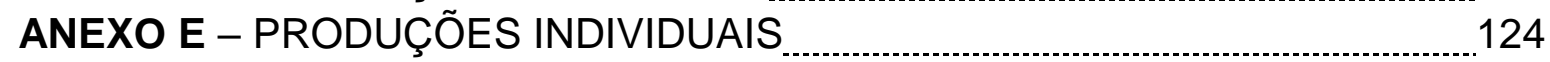




\section{PERCURSO PROFISSIONAL DA AUTORA}

Atuo na área da educação desde 2007, comecei como professora substituta na cidade de São Bernardo do Campo, na escola estadual Célio Luiz Negrini. Em 2010, assumi as turmas de recuperação paralela, na escola estadual Professor José Jorge do Amaral. As aulas eram ministradas no contra turno, em grupos reduzidos, com o objetivo de sanar dificuldades na disciplina Língua Portuguesa por intermédio de atividades diversificadas (jogos, saraus, oficinas de escrita e leitura etc.).

Em 2011, assumi o cargo de professora de Língua Portuguesa no município de São Paulo. Trabalhei na escola Vinícius de Moraes, na Zona Leste, em região periférica, como orientadora do projeto Sala de Leitura, que acontece nas bibliotecas das escolas da rede, ainda hoje. Atendia os discentes do ensino fundamental I e II. O objetivo geral do projeto visa a despertar o gosto pela leitura. As atividades e oficinas têm por objetivos: i) mobilizar a curiosidade pelos livros; ii) efetuar leituras como instrumentos para a aquisição de conhecimento; iii) efetuar leituras pelo prazer que elas podem proporcionar.

Em 2012, assumi o cargo de professora de Língua Portuguesa, do estado de São Paulo, com acúmulo de cargo: no período da manhã, trabalhava na prefeitura de São Paulo e, à tarde, na escola estadual Professora Maria Pires, localizada em São Bernardo do Campo. Lecionei nessa escola, até fevereiro de 2014, ano em que pedi exoneração para assumir o cargo de professora na prefeitura de São Caetano do Sul.

No ano de 2013, fui removida para a escola municipal Desembargador Achilles Ribeiro, na zona leste de São Paulo e deixei o projeto sala de leitura para atuar como professora de Língua Portuguesa nos nonos anos, até fevereiro de 2016, quando me exonerei, para cursar o mestrado profissional em rede - PROFLETRAS. As aulas, deste projeto são ministradas nas quintas e sextas-feiras, por isso o acúmulo de cargos ficou inviável. Tendo que optar entre as prefeituras de São Paulo e São Caetano do Sul, escolhi esta última por ter a escola mais próxima de minha residência.

Em 2014, ingressei na rede municipal de São Caetano do Sul como professora de Língua Portuguesa e Língua Inglesa no Ensino fundamental II, na 
escola municipal 28 de Julho. Leciono, atualmente, no período da manhã, em classes do sexto ano. Como professora titular da sala, percebi que a falta da recorrência ao texto para justificar este ou aquele sentido a ele atribuído é uma constante. Muitas vezes, o estudante não consegue entender o que acabou de ler, tem dificuldades de localizar informações e fazer inferências que o auxiliariam a compreender o texto. Outro fato que chama minha atenção é a ruptura em relação à leitura literária, que também, é recorrente. Cabe observar que esses problemas, nessa escola, ocorrem em menor grau, se comparados às outras redes em que trabalhei (prefeitura e estado de São Paulo).

Além das aulas, no contra turno, desenvolvi, nesse estabelecimento, o projeto do jornal da escola, para estimular a leitura e a escrita como fonte de pesquisa. A inscrição dos alunos é facultativa. Após pesquisas, os alunos desenvolvem textos da esfera jornalística, com temáticas variadas, destinados a serem lidos pelos pais e por outros alunos. A publicação é trimestral.

Embora pertencentes a uma comunidade leitora, a maioria dos estudantes leem somente os livros paradidáticos exigidos pela escola (um a cada trimestre). Além disso, rejeitam as atividades de produção textual, executando-as rapidamente para 'livrarem-se' do fardo que a escrita representa. Tendo passado por algumas escolas de diferentes redes, consegui perceber que existem perfis diversos de educandos, porém as dificuldades quanto ao aprendizado são bastante parecidas.

Por isso, quis ingressar no PROFLETRAS e dedicar-me a ele, com o intuito de encontrar novas perspectivas junto ao corpo docente especializado e ao grupo de colegas que enfrentam desafios semelhantes. No PROFLETRAS, tivemos muitas discussões acerca da educação nas escolas públicas, que me conduziram a refletir, de modo aprofundado sobre a realidade de meus alunos, para delinear propostas que minimizassem a dificuldade deles em relação à escrita de textos, em particular, os literários.

Sendo está a minha principal preocupação, o corpus desta pesquisa, buscou trabalhar com a escrita e a leitura do gênero poema, para que o estudante aprimore sua capacidade de leitura. $O$ intuito é conferir-lhes o desenvolvimento gradual da autonomia na formação leitora e escritora, de modo dinâmico e lúdico, principalmente, a textos literários, que parecem apresentar uma barreira para 0 segmento com o qual trabalho, o Ensino fundamental II. 
A ideia de trabalhar com poemas, gênero matriz para a composição da proposta didática, deu-se por dois motivos - i) faz parte da proposta curricular da prefeitura de São Caetano do Sul; ii) os poemas infanto-juvenis e infantis despertam a imaginação, suas composições estéticas alinham texto e lúdico; é possível extrair leituras plurais aguçando a percepção e curiosidade do leitor. 


\section{INTRODUÇÃO}

A pesquisa corrobora com a proposta de Mestrado Profissional em Letras - PROFLETRAS - que objetiva fomentar a capacitação contínua (prevista em lei LDB/1996 ${ }^{1}$ ) dos professores de escolas públicas de Língua Portuguesa com vistas a unir arcabouço teórico às práticas quotidianas, aprimorando o trabalho docente e, consequentemente, os processos de ensino e aprendizagem da língua materna.

$O$ ato de ler e escrever, na escola contemporânea, ultrapassa a concepção de alfabetização. $O$ termo letramento ${ }^{2}$, utilizado atualmente, amplia a aquisição da competência leitora e escritora: além de decifrar a língua materna, os usuários da língua devem entendê-la como recurso utilizado na comunicação, em diferentes esferas sociais. Assim, para muitos autores, como Kleiman $(1998,2007)$, Antunes (2009) e Rojo (2004, 2004a, 2005), as práticas de leitura e escrita, na instituição educacional, visam à formação de um sujeito capaz de tornar-se cidadão da cultura escrita e da (permanente) leitura de mundo.

A competência escritora e leitora, neste contexto, é material basilar para "[...] o desenvolvimento do pensamento antecipatório, combinatório e probabilístico que permite estabelecer hipóteses, inferir informações, avaliar de forma crítica/reflexiva [...]" os textos usuais e literários, além das diversas situações que envolvem a comunicação cotidiana (SÃO PAULO³, 2012, p. 17).

Logo, as habilidades de leitura e escrita, estimuladas no contexto escolar, deveriam permitir a participação ativa dos sujeitos em sociedade, ao longo de toda a vida. Contudo, estudos avaliativos da educação constatam que, muitas vezes, é um desafio para o estudante interpretar e compreender os textos e, mais ainda, fazê-lo de forma crítica. Falta-lhe, justamente, dominar a língua e seus recursos para atribuir sentido aos textos escritos, dificuldade que, inevitavelmente, é refletida na produção textual.

Esse fato revela-se nos baixos índices de rendimento/desempenho

\footnotetext{
${ }^{1}$ Leis de Diretrizes e Bases da Educação Nacional - 9394/1996 (BRASIL).

2 O conceito de letramento emerge no Brasil, na década de 1980. A palavra letramento deriva do francês e do inglês, respectivamente - illettrisme, literacy.

A entrada ao mundo da escrita e da leitura ocorre, simultaneamente, por dois processos: "[...] pela aquisição do sistema convencional de escrita - a alfabetização - e pelo desenvolvimento de habilidades de uso desse sistema em atividades de leitura e escrita, nas práticas sociais que envolvem a língua escrita - o letramento" (SOARES, 2004, p. 14).

${ }^{3}$ PCESP - Proposta curricular do estado de São Paulo, 2012.
} 
apresentados pelas avaliações externas. De acordo com o Instituto Nacional de Estudos e Pesquisas Educacionais Anísio Teixeira - INEP (BRASIL, 2016), o ensino de Língua Portuguesa, no ensino fundamental I, apresenta melhora sistêmica em seus resultados, ${ }^{4}$ contudo, os alunos do fundamental II, não conseguem avançar. Os resultados das duas últimas avaliações não atingiram a média estabelecida pelo Ministério da Educação - MEC5 (BRASIL, 2016).

Os discentes apresentam dificuldades de interpretar e compreender tanto textos usuais quanto literários, sobretudo quando as informações estão implícitas ou subentendidas e exigem uma análise que ultrapassa a horizontalidade da superfície textual. Essas dificuldades se refletem, comumente, nas produções escritas, realizadas sem o devido aprofundamento das opções que a língua oferece para a elaboração do texto. Tais defasagens seguem até o fim do ensino médio, conforme análises efetuadas nas redações do Exame Nacional do Ensino Médio - Enem6.

Leituras efetuadas, nos estudos de Kleiman (2007), Rojo (2004a) e Antunes (2009), evidenciam que o letramento, na escola, está arregimentado em práticas etnocentradas, fundamentadas em caráter monocultural, fato que conduz os estudantes a produzir textos, sem considerar o interlocutor, ou seja, sem construir sentido para a leitura daquilo que escrevem.

Por isso, o que se encontra na escola, é um leitor/escritor desinteressado e desestimulado, alunos que concebem o ato de ler e escrever como atividades "[...] áridas e tortuosas [...] que não tem nada a ver com atividade prazerosa [...] ninguém gosta de fazer aquilo que é difícil demais ou de que não consegue extrair sentido". Fica, assim, sugerida a necessidade de reformular a prática pedagógica para

\footnotetext{
${ }^{4} \mathrm{Na}$ comparação dos resultados entre 2005 e 2015, observa-se que, em 2005, a nota para Língua Portuguesa no fundamental I foi de 3,8 e, em 2015, a nota atingiu 5,5. Desde a primeira avaliação feita, em 2005, a escola pública em média consegue atingir as metas propostas para o ensino fundamental I (BRASIL, INEP, 2016).

5 Em relação ao ensino fundamental II, as médias propostas eram de 4,2 e 4,5 respectivamente. Porém, nas duas últimas avaliações, as médias ficaram entre 4,0, em 2013, e 4,2, em 2015, ou seja, não conseguiram atingir o proposto pelo Ministério da Educação. O ensino médio não avança, desde as últimas três avaliações, reflexo das dificuldades em interpretar e compreender textos, oriundos do ensino fundamental II. (BRASIL, INEP, 2016).

${ }^{6}$ Mais de 53 mil candidatos que realizaram o Enem em 2015 zeraram a nota da redação. A maior parte dos candidatos atingiu entre 501 e 600 pontos (ao todo, 1.987.251 estudantes). Quase 1,4 milhão de alunos obtiveram mais de 600 pontos. Somente 104 estudantes tiraram nota mil e quatro acima de mil. Disponível em:

<http://educacao.uol.com.br/noticias/2016/01/11/enem-mais-de-53-mil-candidatos-tiraramnota-zero-na-redacao.htm> Acesso em 15/11/2016.
} 
incentivar a leitura e escrita vinculadas ao uso da linguagem e do saber linguístico e que façam sentido para o estudante (KLEIMAN, 1998, p.16).

Desse modo, a presente pesquisa se justifica pela necessidade de propor atividades didáticas que motivem o desenvolvimento das habilidades de leitura e escrita, para que o aluno consiga utilizar a linguagem, observando o alcance de seus recursos linguísticos e expressivos, para interpretar e produzir textos.

As habilidades de leitura e escrita relacionam-se à literatura7, "[...] cuja relevância no desenvolvimento emocional, intelectual, político e cultural da criança, permitem despertar o gosto pela leitura [...]", corroborando com o desenvolvimento identitário do leitor e a manifestação de indícios de autoria nos textos escritos (MAIA, 2007, p.17).

Ambos os temas - leitura e literatura - se relacionam, porque "[...] enquanto ação cognitiva e interlocutiva, o segundo é objeto de reflexão do primeiro, ou melhor, a literatura 'avulta como o modelo por excelência da leitura'”. A sala de aula é ambiente propício para estimular o gosto pela leitura, pois é um espaço privilegiado para o "[...] intercâmbio com a cultura literária [...]". A literatura é importante no contexto escolar porque "[...] é um fenômeno de criatividade, aprendizagem e prazer, que representa o mundo e a vida através das palavras". Ou seja, por meio da leitura literária, supõe-se que ocorrerá o desenvolvimento da formação leitora (ZILBERMAN, 2003, p.19).

\begin{abstract}
A leitura, como prática sociocultural deve inserir-se em um conjunto de práticas sociais e não exclusivamente escolarizadas, pensar no processo de aquisição da leitura extrapola a prática restrita do ambiente escolar - mas sem dúvida não pode prescindir dele, justamente, por ser a instituição das mais democratizadas, por qual quase todos conseguem chegar e passar (BERENBLUM; PAIVA, 2009, p. 17).
\end{abstract}

A função docente, em aula, é estimular o estudante a desenvolver as habilidades de leitura e escrita, o que não impede de o aluno, também, ser estimulado em outros ambientes e por outras pessoas. A leitura, em casa, com pais

\footnotetext{
7 Mas não só ela, a competência leitora e escritora são desenvolvidas por meio de atividades que envolvem vários tipos de texto e contextos sociais diversos - a literatura tem papel relevante no desenvolvimento das habilidades leitoras, porém não é a única fonte para sua aquisição. Ao relacionar a concepção de leitura e escrita, enquanto práticas sociais, notam-se inúmeros textos de diversas esferas que chegam aos alunos e possibilitam, também, a aquisição da competência leitora e escritora (KLEIMAN, 2007).
} 
ou amigos, a leitura individual de diversos textos e fontes é importante no desenvolvimento da competência leitora e escritora.

Nesta pesquisa, pretende-se buscar estratégias que contribuam com o processo de ensino e aprendizagem de forma contextualizada, para o desenvolvimento das habilidades de escrita, tendo como ponto de partida a leitura de poemas. O objetivo central é sequenciar atividades para propiciar situações favoráveis ao estudante e ampliar suas habilidades de compreender e interpretar poemas, incorporando a leitura como fonte de conhecimento. O intuito é analisar por meio da elaboração e aplicação da proposta didática, se a leitura e respectivos comentários orais, bem como as atividades de escrita auxiliam o estudante de sexto ano a escrever poemas com autonomia.

A escolha do gênero poema apoia-se na afirmação de Zilberman (2003, p. 13): "[...] o texto poético favorece a formação do indivíduo, cabendo, pois, expô-lo à matéria-prima literária, requisito indispensável a seu aprimoramento intelectual e ético".

Viabilizar o desenvolvimento das competências de leitura e escrita aliadas à construção identitária do sujeito é responsabilidade da escola. Para salvaguardar a aprendizagem, a experiência aqui relatada volta-se para o processo de ensino e aprendizagem executado por meio do dinamismo lúdico, buscando aproximar a criança do gênero poema. Brincar com as palavras, escrevê-las de forma lúdica pode conectar o leitor ao mundo da criatividade, da imaginação e da ousadia. $O$ professor tem papel central, ao atuar como mediador "[...] sensível ao texto poético [...]", importante na "[...] formação do gosto pela poesia" (SORRENTI, 2009, p. 19).

A hipótese estabelecida por esta pesquisa é que mediante a leitura e escrita de poemas, a criança desenvolva habilidades que ampliarão sua competência leitora e escritora, despertando 0 seu senso estético, concomitantemente, ao exercício do entendimento textual. Interpretar e explorar as características do gênero seria, a meu ver, a motivação para levá-la a produzir poemas com autoria por meio de uma proposta didática bem planejada e, ainda, a ampliar sua competência para o manejo de outros gêneros textuais.

Isso poderá ocorrer porque a literatura, sobretudo, a poesia "[...] é produto de um trabalho estético com a linguagem que, ao representar a realidade, o faz assegurando o princípio de polissemia, isto é, a possibilidade de o leitor extrair múltiplos sentidos". Mais que a polissemia, o estudo do poema permite a percepção 
da plurissignificação da linguagem literária, já que ela decorre dos recursos linguísticos e organizacionais presentes no texto (BRAGATTO FILHO, 1995, p.16).

A percepção da plurissignificação em textos literários requer o planejamento de atividades que não devem se ater às fórmulas convencionais de leitura, principalmente, no caso do poema que traz em seu bojo tratamento próprio. Neste sentido, o gênero poema, por sua elaboração, requer do leitor a interação com a leitura para entender os sentidos do texto nem sempre explícitos. Logo, "[...] é ampla a gama de possibilidades de trabalho que ele permite" (GOLDSTEIN, 1999, p.144).

Este trabalho organiza-se em quatro capítulos.

O primeiro capítulo faz referência ao ensino da língua materna em seu percurso sócio histórico, com ênfase nos documentos oficiais que embasam a educação no país. Ressalta a importância de diversificar os textos em aula, com fundamento nas proposições de Bakhtin (2016) e Adam (2011). Trata da sequência didática difundida por Dolz e Schneuwly (2004) para salvaguardar aprendizagens significativas por meio do uso dos gêneros textuais. Embasa-se, ainda, nos conceitos de letramento difundidos por Soares (2002, 2004), Rojo e Cordeiro (2004), Rojo e Moura (2012).

O segundo capítulo comenta o trabalho com a literatura na escola, com ênfase no gênero poema e suas características. Recorre aos teóricos da estilística, dentre os quais Martins (2008) e da literatura, como Bosi (2000). Ressalta, também, o caráter dialógico de todo enunciado, bastante acentuado nos textos literários que estimulam as relações interativas entre leitor/ autor/ texto, com fundamento em Bakhtin (2016).

O terceiro capítulo apresenta a proposta didática planejada e aplicada. Descreve o contexto e o perfil da turma que participou da pesquisa, bem como a metodologia e as concepções sobre o trabalho com o poema, segundo Jolibert (2009); Dolz, Noverraz e Schneuwly (2004). Dedica espaço ao caráter lúdico presente nas atividades, de acordo com Macedo, Petty e Passos (2007). Relata, ainda, as aulas em que a proposta didática foi aplicada.

O quarto capítulo traz a análise do corpus da pesquisa, resultante da aplicação exposta no capítulo anterior. A análise dos poemas (produto final da 
proposta didática) fundamenta-se no trabalho com o gênero poema, segundo Candido (1996), Jolibert (2009), Goldstein (1999; 2006; 2007) e Levin (1975); embasa-se nos estudos estilísticos de Martins (2008); e nos processos de construção da autoria por Tfouni (2015), bem como os processos de construção de èthos proposto por Fiorin (2008) e estilo proposto por Possenti (2007) e agência segundo Bazerman (2006).

O conjunto é arrematado pelas considerações finais. 


\section{DIVERSIDADE TEXTUAL NA FORMAÇÃO LEITORA E ESCRITORA - UM PERCURSO SÓCIO HISTÓRICO}

As mudanças de paradigma na educação ocorridas no país, nas décadas de 1980 e 1990 ecoam, fortemente, na educação do século XXI. Por isso, este capítulo discorre sobre as principais mudanças no processo de ensino e aprendizagem de Língua Portuguesa, com ênfase nos documentos oficiais que norteiam a aquisição da competência leitora e escritora, com base nas proposições de Bakhtin (2016) e Adam (2011). Este capítulo fundamenta-se, também, nos conceitos de letramento com base nos estudos de Rojo e Cordeiro (2004); Rojo e Moura (2012); e Soares (2002).

\subsection{LEITURA E PRODUÇÃO DE ESCRITA: DO ENSINO TRADICIONAL ÀS PERSPECTIVAS CONTEMPORÂNEAS}

O componente curricular - Língua Portuguesa - foi instituído, no Brasil, no século XVIII. O Marquês de Pombal estabeleceu sua obrigatoriedade, proibindo o uso de outras línguas nas escolas. O conceito de estudo da língua pautava-se pelo ensino da gramática normativo-descritiva até o século XIX, à época, o processo de ensino estava estruturado na memorização de regras e em procedimentos similares aos do estudo da gramática latina, mantida no currículo até o início do século $X X$ (SOARES, 2002).

Para Houaiss (1985, p. 25):

Um traço equívoco da política linguística adotada no Brasil e em Portugal durante um grande lapso de tempo (de 1820) [...] a 1920 [...] foi um ensino da língua que postulava uma modalidade única do português - com uma gramática única e uma 'luta' acirrada contra as variações até de pronúncia.

O ensino da língua preservava o bem falar e o bem escrever por meio do uso correto da gramática (da variedade que hoje designamos "língua culta padrão"), por isso, o cerne dos estudos estava nas regras de escrita. O ensino partia da premissa de que a gramática normativa conduziria ao domínio da produção escrita. Até a década de 1950, o ensino da língua manteve a tríade: retórica, poética e gramática. Com o passar do tempo, a retórica e a poética começaram a assumir 
traços de estudos estilísticos, voltados à leitura comentada dos cânones da literatura. A gramática, de certo modo, continuou como conteúdo autônomo no ensino da língua (SANTOS et al, 2007, p. 33).

A retórica servia como base para desenvolver os discursos orais e escritos. Estudavam-se as obras para incluí-las no próprio discurso, por alusão ou citação, como argumento de autoridade. No século XIX, esse modelo de ensino é complementado pelo estudo da História da Literatura, seguindo a cronologia literária (COLOMER, 2007).

\begin{abstract}
Assim, pois, até há relativamente pouco tempo, as obras deliberadamente 'escolares' e as antologias de texto e autores conhecidos foram os livros mais presentes nas aulas. No melhor dos casos tratava-se de 'belas páginas' para moldar o gosto e imitar nos exercícios de redação; poemas e fragmentos para memorizar e compartilhar como referências da coletividade cultural ou nacional; e fábulas e contos morais curtos para educar em relação aos valores e comportamentos (COLOMER, 2007, p. 17).
\end{abstract}

Os fragmentos de textos eram usados para "[...] comprovar os juízos de valor [...]" e as características de cada escola literária. Ainda hoje, a literatura avulta em muitas instituições, com o modelo "[...] patrimonial e historicista [...]" em que o estudante executa as leituras literárias com o intuito único de adquirir aparato instrumental para efetuar "[...] a análise textual própria da função de um leitor profissional especializado" (COLOMER, 2007, p. 31).

Nos anos de 1970 e início dos anos de 1980, a disciplina Língua Portuguesa é considerada instrumento para o desenvolvimento econômico do país. A Teoria da Comunicação é incorporada ao currículo e, como consequência, os objetivos do ensino tornam-se utilitários e pragmáticos. Na segunda metade da década de 1980, a Teoria da Comunicação sofre muitas críticas e o ensino de língua, pautado por ela, deixa de ter apoio político e ideológico. A Linguística e a Psicologia da aprendizagem são difundidas no país. Dessa forma, passa-se a defender a concepção de língua como enunciação, como discurso (SOARES, 2002).

Em 1980, os estudos relativos à língua integram os currículos para a formação docente. Inicialmente, a linguística, posteriormente, a sociolinguística, mais recentemente a psicolinguística, a linguística textual, a pragmática, a análise do discurso - só nos anos de 1980 essas ciências chegam à escola, aplicadas ao ensino da língua materna (SOARES, 2002, p.168). 
As pesquisas realizadas no campo da Linguística viabilizaram a compreensão e possíveis explicações sobre o fracasso escolar do país ${ }^{8}$, possibilitando intervenções nos processos educativos, na tentativa de solucionar as lacunas do ensino de Língua Portuguesa (SOARES, 2002).

Os estudos, no campo da Línguistica, trazem à luz discussões acerca das teorias interacionistas que concebem a linguagem verbal como atividade interativa de comunicação. Essas teorias abrangem o campo da filosofia e da linguagem, com o suporte teórico de Bakhtin que conceitua a palavra como um instrumento de ordem psíquica, ideológica e sociológica, afirmando que todo "[...] signo é social por natureza, tanto no exterior quanto no interior". Ressalta, também, que "[...] a verdadeira substância da língua é o [...] fenômeno social da interação verbal, realizada através da enunciação ou das enunciações" (BAKHTIN, 2016, p.123).

No campo da psicologia, destaca-se Vygotsky e a teoria sobre Pensamento e Linguagem. Para Vygotsky, o homem é historicamente social, pois é a relação com o outro que conduz à construção de conhecimentos, que desencadeia os processos de desenvolvimento intelectual. O desenvolvimento do pensamento é determinado pelo uso da linguagem, na interação social e na mediação. "O aprendizado é uma das principais fontes de conceitos da criança, e é também uma força que direciona o desenvolvimento, determinando 0 destino de todo 0 desenvolvimento mental" (VYGOTSKY, 2000, p.74).

Além das contribuições das ciências linguísticas e da Psicologia, as áreas que abrangem a História da leitura e da escrita, a Sociologia da leitura e da escrita e a Antropologia da leitura e da escrita, também, passaram a orientar a disciplina Língua Portuguesa porque introduziram a necessidade de estudar a língua por meio do viés cultural e sócio histórico (SOARES, 2002).

\footnotetext{
${ }^{8} \mathrm{O}$ fracasso da educação, no país, foi considerado de tal magnitude, que a partir da década de 1960 já havia discussões sobre a ineficácia da educação. Entre as décadas de 1960 e 1970 , as taxas de reprovação chegavam a $63 \%$, a taxa de evasão, no ensino primário, era de $44 \%$, no secundário $22 \%$ e no terciário $17 \%$. Em 1980 , com os estudos no campo da Linguística e mudanças de paradigma no ensino da Literatura, pesquisadores e estudiosos buscaram analisar as causas do fracasso escolar sob diferentes prismas, com o intuito de instaurar novas concepções de ensino. (FREITAG, 1980). Em 1990, apesar da redução, os índices de reprovação e evasão eram altos. Em 1997, dois anos após a primeira publicação dos PCNs, a cada 100 crianças que iniciavam o ensino fundamental, apenas, 66 terminavam a oitava série (LAHOZ, 2000).
} 
Em consequência desta concepção de língua, o texto adquire um papel relevante no ensino, tanto da leitura quanto da escrita. [...] passa a ser o centro do ensino de língua prescrito, tendo a gramática um papel secundário e posterior ao domínio e ao uso da linguagem (SANTOS et al, 2007, p.33).

A mudança de paradigma traz à tona a importância de diversificar os textos em sala de aula, para auxiliar o processo de desenvolvimento das habilidades de escrita e leitura, "[...] coloca-se, então, a necessidade de levar o aprendiz ao domínio dos diferentes textos tal qual eles aparecem nas práticas de referência" (SANTOS et al 2007, p.36). Os gêneros textuais passam a integrar o currículo como estratégia basilar para o ensino da língua em todas as suas vertentes (BRASIL, 1998).

Com relação ao ensino de gramática, o foco passou a ser a gramática de uso, ou seja, a análise dos recursos linguísticos presentes no texto, a fim de verificar quais efeitos de sentido eles produzem. Em muitas escolas, a gramática de uso suscitou equívocos nas práticas educativas. Alguns programas de educação deduziram que não era mais necessário ensinar gramática; assim muitos professores, de modo equivocado, não interferiam de modo profícuo no processo de letramento do estudante, deixando de lhe passar importantes informações sobre os recursos linguísticos e sobre seus próprios equívocos na escrita. Em contrapartida, em outros estabelecimentos, os textos continuaram (e continuam, ainda) a ser usados como pretextos para o modelo tradicional de ensino, ou seja, como pretexto para extrair deles alguns exemplos que possibilitem o estudo de regras gramaticais tal qual prescreve a língua padrão. Em ambos os casos, notam-se prejuízos ao desenvolvimento cognitivo das habilidades de leitura e escrita, decorrente da falta de integração entre o uso da língua e o conhecimento dos recursos linguísticos (SANTOS et al, 2007).

O ensino da língua, reformulado com base nas contribuições da Linguística, juntamente, com as mudanças sociais e políticas no país, em meados de 1990, levaram a escola pública às seguintes necessidades: i) considerar a diferença entre a linguagem utilizada e difundida na sala de aula e a linguagem utilizada pelos estudantes em seu quotidiano; ii) considerar e respeitar a variação linguística; iii) relacionar ensino da língua a práticas pedagógicas democráticas e transformadoras; e iv) divulgar os conhecimentos linguísticos para alterar as práticas pedagógicas existentes (DE PIETRI, 2003). 
Desse modo, na década de 1990, buscam-se consolidar práticas educativas que respeitam as variações linguísticas e ensinam a gramática por meio de textos contextualizados e autênticos, que circulam nas diversas esferas sociais. Neste contexto, os Parâmetros Curriculares Nacionais - PCNs (BRASIL, 1998) representam um considerável subsídio ao avanço da educação brasileira, principalmente, no que tange as aulas de Língua Portuguesa e as políticas linguísticas que atuam contra o analfabetismo funcional e favorecem a construção da cidadania crítica (ROJO, 2004).

Contudo, no afã de seguir as concepções vigentes dos documentos oficiais, alguns equívocos colaboraram para deixar a literatura fora da sala de aula, pressupondo que qualquer leitura e escrita voltadas à imaginação, fantasia e criatividade seria "fuga da realidade" do aluno. Para Belintane, o principal equívoco está em considerar como ideal, na escola, somente o texto "real", "autêntico", ou seja, aquele que está nas esferas de comunicação rotineiras da sociedade, "[...] desde o rótulo do pacote de salgadinho até o anúncio publicitário exposto nos outdoors e internet [...]" (BELINTANE, 2013, p.119).

Para incorporar tais gêneros textuais, foram deixadas de lado as literaturas que poderiam, perfeitamente, conviver com esses gêneros e, ainda, colaborar com a aquisição das habilidades de leitura e escrita. Belintane afirma que essa tendência criou oposição entre a "[...] função poética e a literatura diante da função comunicativo-pragmática dos textos oriundos do universo de letramento imediato da criança (gêneros do cotidiano)" (BELINTANE, 2013, p.120).

É importante que todos os gêneros circulem na sala de aula, sem que um ganhe destaque em detrimento do outro, pois cada qual tem sua função e devem ser conhecidos pelos estudantes. Belintane (2013, p. 125) ressalta que:

\begin{abstract}
A fala, os gêneros, textos e discursos que banham o cotidiano da criança constituem de fato dimensões importantes da língua e da linguagem, mas não possuem o mesmo relevo e poder que os textos oriundos da tradição oral e os literários exercem sobre o imaginário infantil. [...] A literatura desloca elementos da realidade, que em geral são recobertos pela função referencial da linguagem [...].
\end{abstract}

Quando é dada à criança a oportunidade de contato com o mistério, a fantasia, o mítico ou o lúdico, "[...] revitalizam-se suas possibilidades de releitura tanto da vida como da palavra". Porém, se em aula a literatura não tem espaço, a 
aprendizagem se dará "[...] unívoca, instrumentalizada pelo uso cotidiano dos adultos". Dificilmente, esse aluno terá desejo pela leitura, "[...] de enfrentar destemidamente textos longos e misteriosos [...]", ficará atado "[...] à correlação direta entre significado e significante ou entre linguagem e o mundo prosaico" (BELINTANE, 2013, p. 123-124).

Os documentos oficiais, instituídos em meados de 1990, voltam a privilegiar o uso de textos literários no Fundamental I, II e no Ensino Médio. No entanto, com exceção do último, há poucas informações indicadoras de como efetivar as práticas educativas voltadas aos textos literários de modo geral e, em particular, ao gênero poema. Os Parâmetros Curriculares e demais documentos ${ }^{9}$ enfatizam que é necessário ampliar o repertório do estudante por meio dos textos usuais e literários, orais e escritos, para que tenha acesso a diferentes gêneros, em afirmações genéricas, sem indicação precisa de estratégias metodológicas.

\subsection{AS PROPOSTAS CURRICULARES DE ENSINO DE LÍNGUA PORTUGUESA}

Os PCNs propõem formar um leitor/produtor competente no uso oral e escrito da linguagem, em diferentes situações comunicativas, que consiga empreender discurso "[...] para construir e reconstruir os sentidos de textos que lê ou produz". Aprender a língua, neste contexto, não se limita a decifrar o código escrito, o desenvolvimento da escrita vai além, pois "[...] abriga na memória de longo prazo, as estruturas gráficas, lexicais, frasais, textuais e esquemáticas necessárias para compreender e produzir, estrategicamente, textos com variadas metas de comunicação" (ROJO, 2005, p. 28).

Dessa forma, nas orientações voltadas ao ensino de Língua Portuguesa, nos documentos oficiais subjazem as concepções de Bakhtin (2016) com apoio na Análise do Discurso. $E$ também, nas sequências didáticas e nos gêneros textuais, com base em Dolz e Schneuwly (2004), como estratégias ou instrumentos para a aprendizagem.

Bakhtin (2016) classifica os gêneros discursivos em primários e

9 Parâmetros Curriculares Nacionais - PCN (1998); Parâmetros Curriculares Nacionais Ensino Médio - PCNEM (2000); Orientações Educacionais Complementares aos Parâmetros Curriculares Nacionais - PCN+ (2002); Orientações Curriculares de São Caetano do Sul OCSCS (2014); Proposta Curricular do Estado de São Paulo - PCESP (2012). 
secundários. Os primeiros são espontâneos; já os segundos são relativamente estáveis, caracterizados pelo conteúdo temático, pela construção composicional (a estrutura) e pelo estilo (usos específicos da língua). Essas três características não são estanques e dependem das condições de produção de cada enunciado, uma vez que "[...] o discurso se molda sempre à forma do enunciado que pertence a um sujeito falante e não pode existir fora dessa forma" (BAKHTIN, 2016, p. 293).

A escolha de um gênero depende da esfera social em que ele vai circular. A temática e o conjunto de participantes determinam a vontade enunciativa ou as intenções do autor. Para Bakhtin, as atividades humanas estão organizadas por situações de interação verbal, de tal modo que a escolha dos gêneros não é espontânea, elas "[...] transitam por todas as atividades humanas [...]" (BRAIT, 2005, p. 88).

Os gêneros secundários surgem nas condições de um convívio cultural complexo, desenvolvido e organizado, apresentam contextos linguísticos criados, por isso, possuem autonomia em relação ao contexto e aos modos de desdobramento do gênero que asseguram "[...] sua definição, seu controle e sua avaliação" (DOLZ; SCHNEUWLY, 2004, p. 31).

Segundo Bakhtin (2016), todo enunciado retoma (um ou mais de um) outro que lhe é anterior, assim como será retomado por outro (s) que virá (ão) depois dele. Desse modo, amplia-se a concepção da interação dialógica da linguagem: não apenas entre interlocutores, mas também, entre enunciados da mesma ou de diferentes épocas. A comunicação é representada pela unidade básica - o enunciado. Seus limites estendem-se pela alternância dos falantes, o que Ihe permite assumir as mais variadas formas. As realizações dos enunciados representam os gêneros discursivos, usados amplamente em todas as esferas de comunicação.

Assim, o documento oficial substitui a taxonomia tradicional e a trilogia clássica (narrar, dissertar e descrever) pelos gêneros, como estratégia didática. A concepção linear de ensino da língua é substituída pela aprendizagem em espiral, na qual os gêneros apresentados são retomados periodicamente, ampliando e aprofundando o conhecimento do estudante (ROJO; CORDEIRO, 2004).

Em uma vertente derivada de Bakhtin, ganham destaque os gêneros textuais, de modo a valorizar as práticas sociais, vistas como atividades de linguagem. 
Ao tomar a língua materna como objeto de ensino, a dimensão de como os sujeitos aprende e de como [...] desenvolvem sua competência discursiva, o ensino [...] deve se dar num espaço em que as práticas de uso da linguagem sejam compreendidas em sua dimensão histórica e em que a necessidade de análise e sistematização teórica dos conhecimentos linguísticos decorra dessas mesmas práticas (BRASIL, 1998, p. 24).

Em decorrência das práticas interativas que suscitam os PCNs (1998), o ensino da língua configura-se em dois eixos: no primeiro, o uso da língua oral e da língua escrita; e no segundo, a reflexão sobre a língua e a linguagem. Os conteúdos referentes ao uso da língua evidenciam os aspectos que caracterizam o processo de interlocução. São eles:

i) Historicidade da linguagem e da língua;

ii) Constituição do contexto de produção, representações de mundo e interações sociais: sujeito enunciador; interlocutor; finalidade da interação; lugar e momento de produção.

iii) Implicações do contexto de produção na organização dos discursos: restrições de conteúdo e forma decorrentes da escolha dos gêneros e suportes.

iv) Implicações do contexto de produção no processo de significação: representações dos interlocutores no processo de construção dos sentidos; articulação entre texto e contexto no processo de compreensão; relações intertextuais (BRASIL, 1998, p. 26).

As práticas de reflexão sobre a língua referem-se às atividades que analisam seu funcionamento em situações de interlocução na escuta, leitura e produção, privilegiando aspectos linguísticos que possam ampliar a competência discursiva do sujeito. São eles: variação linguística (modalidades, variedades, registros); organização estrutural dos enunciados; escolhas lexicais e redes semânticas; processos de construção de significação e modos de organização dos discursos.

A diversidade textual, em aula, permite que os alunos estabeleçam diferentes relações entre os textos, conseguindo realizar procedimentos que identificam as referências ou remissões a outros textos, além de executar análises; estabelecer relações temáticas ou estilísticas entre dois textos de diferentes autores ou de diferentes épocas (BRASIL, 2000).

Ela permite, ainda, apresentar ao estudante diversas formas de expressão, juntamente com os textos verbais, fomentando o multiletramento na escola. Neste sentido, "trabalhar com multiletramento pode ou não envolver o uso de 
novas tecnologias de comunicação e de informação [...]", envolve atividades que partem das culturas de referência do estudante, "[...] para buscar um enfoque crítico, pluralista, ético e democrático - que envolva a agência - de textos/discursos que ampliem o repertório cultural, na direção de outros letramentos [...]" (ROJO; MOURA, 2012, p. 08).

\begin{abstract}
Além disso, trabalhar com os multiletramentos partindo das culturas de referência do alunado implica a imersão em letramentos críticos que requerem a análise, critérios, conceitos, uma metalinguagem, para chegar a propostas de produção transformada, redesenhada, que implicam agência por parte do alunado (ROJO; MOURA, 2012, p. 09).
\end{abstract}

Os documentos oficiais, sobretudo os PCNs (1998) voltados ao ensino fundamental II, referem-se às concepções de Adam (2011, p.118), no que concerne às sequências tipológicas constituintes dos textos. $O$ modelo teórico fundamenta-se, dentre outros fatores, pela organização sequencial ou linear do conteúdo temático.

As sequências são grupos de proposições hierarquicamente constituídas, compondo uma organização interna própria de relativa autonomia, que não funcionam da mesma maneira nos diversos gêneros e nem produzem os mesmos efeitos: assumem características específicas em seu interior. Podem se caracterizar como narrativa, descritiva, argumentativa, expositiva e conversacional (BRASIL, 2000, p.21) ${ }^{10}$.

As sequências básicas podem ser combinadas em um texto, o que gera a diversidade das modalidades de organização, garantindo a heterogeneidade composicional dos textos. Uma sequência é "[...] uma rede relacional hierárquica: uma grandeza analisável em partes ligadas entre si e ligadas ao todo que elas constituem; [...] dotada de uma organização interna que lhe é própria". Essa definição centra-se no fato de que a sequência textual é um tipo de "[...] operação de textualização, uma estrutura composicional de natureza linguística, mas que sofre interferências das práticas discursivas" (ADAM, 2011, p. 204).

Os PCNs (1998) adotam a perspectiva de Koch (2004) em relação à competência textual que permite ao falante distinguir os gêneros textuais uns dos outros, conforme sua experiência/vivência e aprendizado na escola. A compreensão

10 Esses termos, em certa época, remetiam a gêneros, quando, na verdade, sabemos, agora, que remetem a sequências textuais. 
de um gênero ultrapassa as análises efetuadas nos aspectos linguísticos e estruturais, abrangendo, também, os aspectos comunicativos e funcionais.

[...] o texto é uma unidade linguística concreta (perceptível pela visão ou audição) que é tomada pelos usuários da língua (falante, escritor e ouvinte, leitor), em uma situação de interação comunicativa específica, como uma unidade de sentido e preenche uma função comunicativa reconhecível e reconhecida, independentemente de sua extensão (BRASIL, 1998, p. 45).

A compreensão textual "[...] é uma atividade interativa altamente complexa de produção de sentidos [...] que requer um vasto conjunto de saberes (enciclopédia) e sua reconstrução no interior do evento comunicativo". A compreensão do texto é "construída na interação texto-sujeitos [...]". O texto não se restringe ao contexto linguístico apenas, mas aos elementos sociais e culturais, associados a elementos linguísticos, cognitivo e social $(\mathrm{KOCH}, 2016, \mathrm{p} .38)$.

Neste contexto, o texto é a matéria prima para as práticas de linguagem. Eles são mediadores entre os diferentes tipos de interação e de interlocução comunicativa, que visam a variadas possibilidades de comunicação. Desse modo, ao diversificar os textos em sala de aula, a aprendizagem torna-se um processo de apropriação que conduz à interiorização de uma prática social, que circula na forma de texto escrito ou oral. Cabe ao docente incentivar à leitura e escrita dos variados tipos de texto, assim como de diferentes gêneros, contextualizando as atividades, entrelaçando-as à realidade do estudante, despertando o gosto pela leitura e escrita como fonte de criação e de recurso para se comunicar com o mundo (DOLZ; SCHNEUWLY, 2004).

O cerne dos documentos oficiais é possibilitar ao estudante o contato com vários tipos de textos: gêneros textuais literários e usuais devem ser apresentados e retomados sistematicamente, discutidos e amplamente divulgados, para ampliar o repertório cultural do aluno e favorecer o desenvolvimento das habilidades de leitura e escrita. 


\subsection{O GÊNERO LITERÁRIO NOS DOCUMENTOS OFICIAIS}

Nas propostas oficiais do ensino fundamental II, há um tópico intitulado: $A$ especificidade do texto literário. Nele, a literatura constitui uma forma peculiar de representar a força criativa e a imaginação. $O$ tópico ressalta que o texto literário não se limita a critérios de observação, nem "[...] às categorias e relações que constituem os padrões dos modos de ver a realidade [...]". O texto literário realiza a mediação entre aluno e mundo por intermédio da ficção e da reinterpretação do mundo, "[...] regido por jogos de aproximação e afastamento em que as invenções, a instauração de pontos de vista particulares, a expressão pode-se misturar a citações do cotidiano [...]" (BRASIL, 1998, p. 26), desse modo:

[...] o texto literário está livre para romper os limites fonológicos, lexicais, sintáticos e semânticos traçados pela língua: está se torna matéria-prima (mais que instrumento de comunicação e expressão) de outro plano semiótico na exploração da sonoridade e do ritmo, na criação e recomposição das palavras, na reinvenção e descoberta de estruturas sintáticas singulares, na abertura intencional a múltiplas leituras pela ambiguidade, pela indeterminação e pelo jogo de imagens e figuras. Tudo pode tornar-se fonte virtual de sentidos, mesmo o espaço gráfico e signos não verbais, como em algumas manifestações da poesia contemporânea (BRASIL, 1998, p.17).

A literatura, na escola, é indispensável por seu caráter único em criar e recriar a língua (e suas variantes) com especificidades próprias do espaço/tempo, situados (ou não) em contextos retirados de situações reais.

Em relação ao texto poético, sua peculiaridade consiste na utilização da linguagem para produzir "[...] efeitos que a linguagem comum não alcança produzir [...]" e, desse modo, "[...] a inferência que se impõe é, então, a de que a poesia não passa de linguagem ordenada ou arranjada de maneira diferente". O referente interno e as peculiaridades do texto poético resultam em uma análise "[...] diferente da que seria produzida por uma análise linguística da linguagem comum" 11. Daí a importância de trabalhar com os poemas em sala de aula, pois a escrita e a análise desses textos diferenciam-se dos demais gêneros, não só por romper os limites da língua, mas por carregar subjetividades que remodelam os contextos ali inseridos (LEVIN, 1975, p. 19).

Gebara ressalta, ainda, que:

${ }^{11}$ As especificidades do gênero poema são retomadas no capítulo II, item 2.2 - Poema. 
Uma das principais características dos gêneros poéticos é fundar seu referente como interno. Essa característica acaba por traçar relações com o referente externo que, por vezes, acontecem com total adesão [...]. Em outros contatos com o poema, porém, essas relações parecem não acontecer - o texto se apresenta, nesse caso, como um enigma - ou, ainda, em outra situação de leitura, as relações são qualificadas como banais - para o leitor -, porque o texto adere de tal forma à realidade que é insuficiente para cumprir o papel ou a representação esperada para uma forma desse agrupamento (2016, p. 15).

No item, $A$ articulação entre as áreas, o documento PCN+ (2002) enfoca a interdisciplinaridade, ao mesmo tempo em que discorre sobre as particularidades da literatura:

[...] além de sua específica constituição estética, é um campo riquíssimo para investigações históricas realizadas pelos estudantes, estimulados e orientados pelo professor, permitindo reencontrar 0 mundo sob a ótica do escritor de cada época e contexto cultural [...]. Esse exercício com a literatura pode ser acompanhado de outros, como as artes plásticas ou a música, investigando as muitas linguagens de cada período (BRASIL, 2000, p. 19).

Há uma latente preocupação, nos documentos oficiais, em articular a literatura à fluência da comunicação, assim como à interdisciplinaridade e à interdiscursividade. Porém, a formação leitora, como construção identitária, do sujeito aparece somente na OCEN (2006). Nela, há uma tentativa clara de relacionar a leitura literária ao desenvolvimento pessoal e autônomo do estudante.

[...] a dimensão formativa do leitor, em processo iniciado no ensino fundamental, que, no ensino médio, se perde em objetivos pragmáticos, formulados, sobretudo, nos manuais didáticos, que, mais para o mal que para o bem, vêm tradicionalmente cumprindo o papel de referência curricular para esse nível da escolaridade. Acreditamos que os manuais didáticos poderão, em médio prazo, apoiar mais satisfatoriamente a formação do leitor da Literatura rumo à sua autonomia (BRASIL, 2006, p. 64).

A relação entre literatura e formação do estudante, enquanto sujeito em permanente construção, cria em aula, espaço para diálogos amplos, em que o professor exercerá o papel de mediador. Essas interações, por vezes, proporcionam situações conflituosas e tensas, já que em grupos heterogêneos, como as salas de aula, é comum encontrarmos crenças, costumes e opiniões mistas. Os gêneros literários, enquanto objeto de estudo, podem desencadear discussões acerca de 
diversos temas, logo, o docente deve preparar-se para afirmações e/ou questionamentos 'inesperados' (que fogem do plano ou do roteiro de aula), propulsores de posicionamentos ímpares entre os colegas/colegas, aluno/professor.

Diante dessas situações, o professor deve respeitar a pluralidade de reflexões, críticas e opiniões que surgem com as variadas leituras e efetuar intervenções que levam o estudante a rever conceitos ou a ampliá-los, para que suas leituras ultrapassem $o$ senso comum, respeitando seu repertório e conhecimento de mundo.

A OCSCS (2014, p. 184) enfatizam os textos literários em todos os anos do fundamental II, contemplam o poema no sexto ano, retomando-o no oitavo. Porém, os textos literários são separados dos demais conteúdo da língua, o que resulta em um currículo fragmentado. O texto literário, nesta proposta, é referendado como "um conjunto de vozes que partem de diversos lugares para além dos espaços geográficos, [...]". Refere-se à literatura como fonte "que cria e recria, em seu arcabouço estrutural e semântico, possíveis realidades, por meio da plurissignificação dos vocábulos".

Ao longo do processo sócio histórico do ensino da língua, os documentos oficiais se destacam por contemplar no currículo aprendizagens centradas no estudante e, por meio da diversidade textual, fomentam a inserção do alunado em diferentes culturas, ampliando e aprofundando seus conhecimentos em relação à língua.

\subsection{SEQUÊNCIA DIDÁTICA: APRENDIZAGEM DA LÍNGUA POR MEIO DO USO DOS GÊNEROS TEXTUAIS}

Com o intuito de garantir a aprendizagem plena e autônoma, Dolz e Schneuwly (2004) justificam a inserção da metodologia dos gêneros, na escola, via atividades didáticas propostas em sequências, que se fundamentam na perspectiva interacionista e na progressão contínua do fluxo de aprendizagem, explorando os conhecimentos prévios e aliando-os a novas aquisições, para ampliar o conhecimento do estudante em relação à língua.

Os gêneros textuais são "[...] ferramentas semióticas complexas", porém mediadoras, capazes de enriquecer as atividades e, consequentemente, a 
aprendizagem. Possibilitam ampliar as capacidades individuais do alunado, ao mesmo tempo em que ampliam o conhecimento sobre o objeto em estudo (o gênero) (SCHNEUWLY, 2004, p. 26).

Para trabalhar com os gêneros em aula, três elementos são essenciais: i) a escolha do gênero definida por parâmetros, dentre os quais a finalidade, os destinatários, o conteúdo temático e o contexto de comunicação; ii) a escolha do gênero de acordo com as especificidades de uso; iii) a escolha do plano comunicacional, caracterizado por um estilo. Neste sentido, o autor afirma que "[...] mesmo a seleção que um locutor efetua de uma forma gramatical já é um ato estilístico" (SCHNEUWLY, 2004, p. 27).

Para Machado e Cristóvão (2006), o trabalho com os gêneros, em aula, exige o recurso da transposição didática. Desse modo, é possível passar os conhecimentos científicos de determinado gênero para o nível dos conhecimentos a serem ensinados e, posteriormente, ao nível que se adapte aos estudantes, de acordo com as especificidades da turma, da escola etc.

Os elementos essenciais do gênero a ser ensinado,

[...] são as características da situação de produção [...]; os conteúdos típicos do gênero; [...] a construção composicional característica do gênero, [...] nesse sentido, podemos dizer que os modelos didáticos podem apresentar falhas ou lacunas, quando vistos do ponto de vista de uma teoria de texto ou discurso qualquer. Mas, na verdade, os pesquisadores que se envolvem na sua construção não estão preocupados em esperar a construção científica ideal, pois têm uma preocupação social imediata, que é a de trazer subsídios para o trabalho docente e para a aprendizagem. A construção de modelos didáticos de gêneros [...] - as sequências textuais [...]; - as características dos mecanismos de coesão nominal e verbal; - as características dos mecanismos de conexão; - as características dos períodos; - as características lexicais (MACHADO; CRISTÓVÃO, 2006, p. 56).

Para elaborar um modelo didático do gênero, deve-se conhecer o estudo dos gêneros, assim como as dificuldades e habilidades dos estudantes. Tais observações auxiliarão a definir a intervenção didática apropriada que poderá ser organizada na forma de sequências didáticas - SD (MACHADO; CRISTÓVÃO, 2006).

SD "[...] é um conjunto de atividades escolares organizadas, de modo sistêmico, em torno de um gênero oral ou escrito" (DOLZ; SCHNEUWLY, 2004, p. 
97). Estas atividades devem:

Permitir o ensino da oralidade e da escrita a partir de um encaminhamento, a um só tempo, semelhante e diferenciado;

Propor uma concepção que englobe o conjunto da escolaridade obrigatória;

Centrar-se, de fato, nas dimensões textuais da expressão oral e escrita;

Oferecer um material rico em textos de referência, escritos e orais, nos quais o aluno possa inspirar-se para suas produções;

Ser modular, para permitir uma diferenciação do ensino;

Favorecer a elaboração de projetos de classe (DOLZ; SCHNEUWLY, 2004, p. 96).

A SD supre as defasagens encontradas na transposição didática porque permite que o professor efetue procedimentos condizentes com a realidade do aluno. Ela deve ser ampla e integrada ao mesmo tempo, já que contempla muitas possibilidades de atividades, imprimindo à aula diversidade e dinâmica. Ela "[...] integra as atividades de leitura, de escrita e de conhecimento da língua, de acordo com um calendário pré-fixado; ela facilitaria a construção de programas em continuidade uns com os outros [...]", além de promover o fator motivação, essencial para a aprendizagem (MACHADO; CRISTÓVÃO 2006, p. 555).

O fator motivação ocorrerá por causa da ampla variedade de exploração que a SD permite, respeitando o repertório cultural e os conhecimentos prévios do estudante. A principal característica da SD é a escolha do objetivo a ser seguido, sempre relacionado a um gênero. Além disso, o projeto ocorrerá em aula, e seu ponto de partida (sempre que possível) será a observação das habilidades e defasagens dos estudantes (DOLZ; SCHNEUWLY, 2004).

Com relação ao gênero - seus componentes seriam trabalhados de modo isolado - com atividades diversas para desenvolver uma metalinguagem sobre seus aspectos (estrutura, unidades linguísticas particulares, elementos do conteúdo etc.). Dolz e Schneuwly (2004) propõem o seguinte esquema para o desenvolvimento da SD:

Quadro 1 - Esquematização da sequência didática

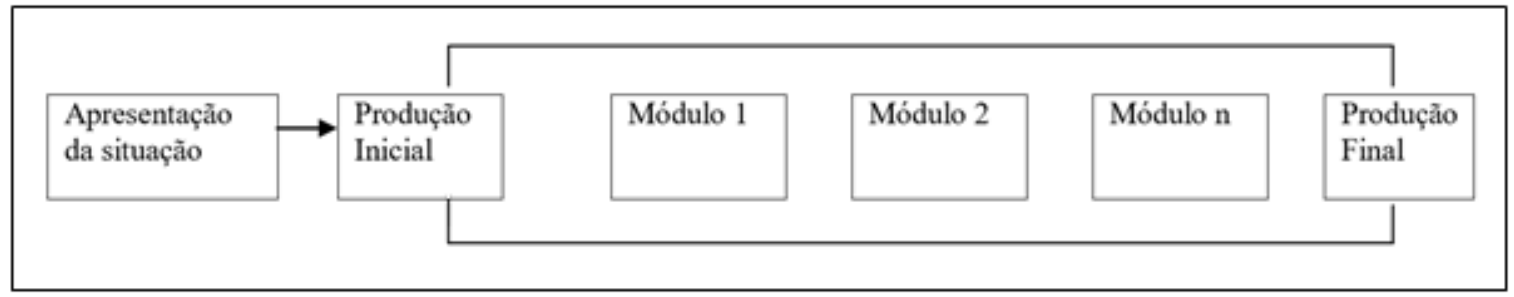

Fonte: (DOLZ; SCHNEUWLY, 2004, p. 98). 
A SD levará o alunado a agregar conhecimentos para a "[...] produção de um texto final pertencente ao gênero, efetuando-se novas observações, análises e a avaliação dos progressos conseguidos e das dificuldades ainda não superadas". A SD prevê que o aluno coloque em prática seus conhecimentos por meio das produções textuais, mas não só nelas. Em todo o processo, o estudante estará em constante aprendizagem, efetuando leituras e escritas pertinentes ao desenvolvimento cognitivo das habilidades em ler e escrever (MACHADO; CRISTÓVÃO, 2006, p. 558). 


\section{LITERATURA NA ESCOLA}

A leitura e a produção de textos literários, na perspectiva interacionista, relaciona a literatura ao contexto sociocultural de produção e recepção. "As obras literárias estabelecem relações intertextuais entre elas, [...] pelo fato de se juntar sob as mesmas regras que configuram os gêneros; [...]" assim, a literatura, ao longo do tempo e entre as culturas, possibilita muitas variações que "[...] formam parte essencial da comunicação literária" (CAMPS et al, 2006, p.73-74).

Deste modo, a literatura seria uma forma de comunicação particular, pois carrega instrumentos únicos em sua composição. Além do sentido inicial proposto pela primeira leitura, o texto literário é elaborado de tal forma, que sua composição conduz o leitor à busca da plurissignificação. Logo, o tratamento didático voltado ao texto poético e aos demais gêneros literários orienta-se para a "[...] valorização e descobrimento de repertório cultural". Visto como objeto linguístico, os gêneros literários nos auxiliam a identificar e compreender o mundo que nos cerca, ao mesmo tempo em que contribuem para explorar nossas capacidades de interpretar e expressar-nos pela linguagem, utilizando-a como "[...] instrumento de comunicação e fonte de prazer estético, emotivo e intelectual" (CAMPS et al, 2006, p.130).

Daí decorre a importância de trabalhar o texto literário, em aula, simultaneamente, como objeto linguístico e objeto estético, para promover as capacidades de leitura e escrita "[...] por meio das formas de imaginação e jogo [...]" (CAMPS et al, 2006, p.130). Este capítulo evidencia o caráter dialógico do texto literário, bem como as características do gênero poema, além de enfatizar seu uso, em aula, via ações didáticas que visam a inter-relacionar as atividades de expressão do gênero, tanto na forma oral como na escrita.

\subsection{CARÁTER ESSENCIALMENTE DIALÓGICO DO TEXTO LITERÁRIO}

A formação leitora é intrínseca ao desenvolvimento identitário do sujeito, é um processo que envolve o leitor e suas experiências sócio históricas. A leitura literária também é um processo interativo. $O$ diálogo ocorre entre o leitor, o texto e 0 autor, já que "[...] a produção de sentido está ancorada nas significações produzidas por esses três elementos" (FIORIN, 2006, p. 32). 
A interação entre os sujeitos, em aula, é imprescindível para o desenvolvimento das habilidades de leitura e escrita. Ao considerar a leitura como um processo interativo e cooperativo, as atividades propostas exploram a interação verbal, mediante as trocas de opiniões, sensações, deduções e pelos debates, com o objetivo de compreender o objeto de estudo (neste caso, o texto literário). A cooperação, na leitura das obras literárias, exige que o leitor compreenda outra consciência - a do autor. Essa possibilidade de leitura conjunta, não deve inibir a leitura autônoma e pessoal, mas incentivá-la.

Temos, assim, a formação da leitura dialógica, que se ancora em constructos bakhtinianos, como a compreensão responsiva ativa. As situações dialógicas são constituídas de enunciados, que interagem e atuam uns sobre os outros, originando condições de respostas e de intercâmbio entre os participantes da comunicação. A enunciação, dessa forma, faz-se "[...] um produto da interação social [...] constitui o conjunto das condições da vida de uma determinada comunidade linguística" (BAKHTIN, 2016, p.121).

Como "[...] a orientação dialógica é naturalmente um fenômeno próprio a todo discurso [...]", a inserção do outro nos discursos tem consequências imediatas. Logo, o conceito dialógico, em sala de aula, dá significado às relações que se desmenbram entre o/os leitor/leitores, autor e o texto. Essas relações auxiliam os estados de compreensão do texto, enquanto objeto discursivo (BAKHTIN, 2016, p.88).

Neste contexto,

[...] o texto é considerado hoje tanto como objeto de significação, ou seja, como um "tecido" organizado e estruturado, quanto como objeto de comunicação, ou melhor, objeto de uma cultura, cujo sentido depende, em suma, do contexto sócio histórico. Concilia-se nessa concepção de texto ou na ideia de enunciado de Bakhtin, abordagens externas e internas da linguagem. $O$ texto enunciado recupera estatuto pleno de objeto discursivo, social e histórico (BARROS, 2003, p.01).

Para compreender um texto de forma plena, é essencial conhecer o seu contexto. Assim, a relação dialógica com a obra literária, também, pressupõe o uso de conhecimentos de mundo e imprime à leitura a compreensão de elementos exteriores ao texto (seu caráter social, histórico, político, ideológico). Em aula, a discussão sobre um texto não se encerra nele, há uma busca para saber quais 
elementos externos contribuíram para sua construção, recuperando os elementos sócios históricos e ampliando a construção de conhecimento.

\subsubsection{Concepção de dialogismo}

O dialogismo constitutivo é feito de enunciados formados a partir de outros que os antecederam, assim como outros o sucederão. Essa relação cria uma cadeia de comunicação. Dessa forma, um enunciado suscita resposta que ainda vai ocorrer, "[...] uma compreensão responsiva ativa constrói-se para uma resposta, seja ela de concordância ou uma refutação" (FIORIN, 2006, p. 32).

Fiorin (2006) conceitua o dialogismo bakhtiniano de três formas. A primeira centra-se na construção dos enunciados, por meio da compreensão responsiva ativa. Não há neutralidade nos discursos, os enunciados são constituídos de significação e sentido, responsáveis pela compreensão ativa e responsiva do sujeito, que estabelece a comunicação entre os interlocutores. Por conseguinte, o sujeito bakhtiniano ${ }^{12}$ é a construção da inter-relação com outros sujeitos sociais, que se relacionam com várias vozes. Para Bakhtin:

O empenho em tornar inteligível a sua fala é apenas o momento
abstrato do projeto concreto e pleno de discurso do falante. Ademais,
todo falante é um respondente em maior ou menor grau: porque ele
não é o primeiro falante, o primeiro a ter violado o eterno silêncio do
universo, e pressupõe não só a existência do sistema da língua que
usa, mas também de alguns enunciados antecedentes - seus e
alheios - com os quais o seu enunciado entre nessas ou naquelas
relações [...]. Cada enunciado é um elo na corrente complexamente
organizada de outros enunciados (2016, p. 272).

A interação discursiva pauta-se pela posição do locutor, na seleção dos critérios e na construção do discurso, que se estabelecem por uma "[...] interconexão da linguagem com a vida social". Essa relação contínua alimenta o fluxo de respostas contextuais e a intervenção das práticas sociais na linguagem (FIORIN,

\footnotetext{
${ }^{12} \mathrm{O}$ sujeito bakhtiniano existe, somente, nos discursos que produz. Bakhtin o define por sua originalidade epistemológica que "[...] ora 'ancora a consciência na palavra', na qual 'a consciência de si é sempre verbal', ora na comunidade, onde o 'eu só pode se realizar no discurso, apoiando-se em nós"' (DAHLET, 2008, p.59).
} 
2006, p. 61).

Ao ler e analisar os enunciados construídos pelo autor, o comportamento leitor não é passivo, a interpretação e a análise textual fomentam considerações sobre o texto. Essas considerações são carregadas de informações exteriores a ele, a leitura estabelece um contínuo de respostas ativas que aceitam ou refutam o texto. Esse fluxo possibilita a dialogia entre leitor, conhecimento de mundo (repertório cultural), autor e obra. Recorremos, para ilustrar o processo, ao poema de Mário Quintana, Canção de muito longe:

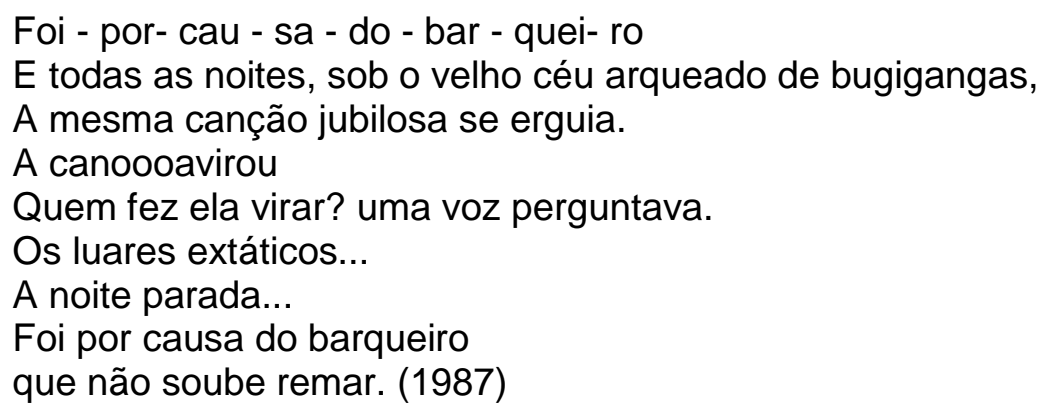

O diálogo que Quintana (1987, p.12) estabelece com a cantiga tradicional, sobretudo, no modo como escreve os versos, auxilia o leitor a acionar seu repertório cultural. No primeiro verso, o poeta usa hífen para sugerir morosidade - a canoa não virou, simplesmente -, mas há indícios que ela o fez de modo peculiar. A escrita desse verso é o elemento que faz o eu lírico recordar, estabelecendo a ponte entre a cantiga de roda e a composição atual. Nos versos quatro e cinco, o autor emprega a junção de palavras. Conduz o leitor à reflexão, ao mesmo tempo em que promove a inserção no passado, pois esses três versos remetem, diretamente, à cantiga de roda. São versos matreiros, musicais, lembram a infância. O poema dá espaço a duas vozes, a da cantiga e a do poeta saudosista que utiliza verbos no pretérito imperfeito como "erguia e perguntava", para indicar uma ação que se repetia no passado. Nos versos seis e sete, o narrador volta para o presente, com frases nominais e, torna-se, agora, a única voz, nos dois últimos versos. Ao retomar a canção, ele o faz de modo diferente, mantém-se no presente. Segundo Goldstein:

A memória do leitor deverá ter registrados o brinquedo de roda, a melodia e a letra da canção que ele vai reconhecer, ao ler no poema a transformação de um enunciado que já fazia parte de sua formação discursiva [...].

No poema, a manifestação dessa retomada aponta para um diálogo 
mais amplo que o textual: o paralelo entre duas épocas diferentes. $\mathrm{O}$ fato de essa canção estar "muito longe", como anuncia o título, refere-se não ao distanciamento no espaço, mas no tempo. O poema faz um apelo à memória e associa a cantiga propriamente dita - com uma escrita diferenciada - à composição poética - com escrita usual. Os dois modos de representar a escrita apontam para a superposição de vozes no poema: a do passado e a do presente; a da cantiga e a do poeta que a recria (1999, p.137).

A retomada da infância, no poema de Quintana (1987), cria outro discurso (que não do autor): o do leitor (que executa a leitura do poema sem passividade). Ele o lê ativa e responsivamente. O enunciado e a enunciação estabelecem o diálogo entre leitor e texto. A construção de sentido se dá com a interação entre o entendimento do texto e o enunciado propriamente dito, considerado "a real unidade da comunicação linguística" (FIORIN, 2006, p.45).

Conforme Bakhtin (2016, p. 132),

[...] o tema da enunciação é determinado não apenas pelas formas linguísticas que entram na composição (as palavras, as entonações, as formas morfológicas ou sintáticas, os sons, as entonações), mas igualmente pelos elementos não verbais da situação.

Os mediadores (em aula, professor e/ou colegas) exercem a importante função de garantir o fluxo responsivo, ao auxiliar o leitor na compreensão textual. Os diálogos acerca das leituras efeituadas ajudam o leitor a posicionar-se perante o texto de modo crítico e reflexivo, observando nuances e inferindo informações que a leitura individual talvez não permitisse. Compartilhar a leitura para fomentar discussões corrobora com a autonomia do leitor porque lhe dá acesso a outros modos de 'entender' o texto (que não só o seu).

Embora o texto literário seja plurissignificante, isso não quer dizer que todas as interpretações sejam válidas, em absoluto. Elas devem ser todas fundamentadas nos elementos do próprio texto, assim como na situação de produção e no contexto.

Os enunciados são definidos em três aspectos: "o horizonte espacial comum dos interlocutores, o conhecimento e a compreensão comum da situação (por parte dos interlocutores) e sua avaliação comum dessa situação". A enunciação é a compreensão dos enunciados, define-se no ato discursivo. A enunciação, no ato da leitura, retoma outras enunciações, para consolidar o entendimento completo do 
texto (BRAIT, 2005, p. 67).

O segundo conceito de dialogismo insere o discurso do outro nas enunciações. O primeiro modo de estabelecer essa inserção é por meio do discurso objetivado (discurso direto, indireto, aspas e negação). O discurso alheio é amplamente utilizado, ainda que nem sempre nitidamente perceptível (FIORIN, 2006, p.33).

Os discursos direto e indireto são considerados:

[...] esquemas padronizados para citar o discurso. Mas esses esquemas e suas variantes só podem ter surgido e tomado forma de acordo com as tendências dominantes da apreensão do discurso de outrem; além disso, na medida em que esses esquemas assumiram uma forma e uma função na língua, eles exercem uma influência reguladora, estimulante ou inibidora, sobre o desenvolvimento das tendências da apreensão apreciativa, cujo campo de ação é justamente definido por essas formas (BAKHTIN, 2016, p. 147).

No discurso alheio não demarcado, as vozes misturam-se, mas continuam nitidamente visíveis. Todo discurso é formado pela incorporação do discurso alheio. $\mathrm{Na}$ literatura, não é diferente: leitor e autor posicionam-se pelo "[...] discurso resultante de outras falas, outros posicionamentos, sendo heterogêneo por natureza" (BAKHTIN, 2016, p.146).

"[...] toda obra literária é interna, imanentemente sociológica. Nela se cruzam forças sociais vivas, avaliações sociais vivas penetram cada elemento da sua forma". O mundo é representado nas palavras, de modo fidedigno ou subjetivo. Os costumes, convenções, regras, afetos/desafetos são explorados por meio da criação de personagens ou eu líricos, enredos que transportam o leitor a um lugar ou época. Nesta direção, a intertextualidade ${ }^{13}$ dialoga com outros textos. Discursos reproduzidos e transformados para suplantar a necessidade do autor (BAKHTIN, 2016, p. 36).

$\mathrm{Na}$ literatura, os julgamentos de valor presumido são particularmente importantes ${ }^{14}$, uma obra poética "[...] é um poderoso condensador de avaliações

${ }^{13} \mathrm{O}$ termo intertextualidade não aparece na obra de Bakhtin. Kristeva (1967) semioticista é quem relaciona o termo à noção de dialogismo. Para Fiorin, qualquer relação dialógica é denominada intertextualidade (FIORIN, 2006).

14 Julgamentos de valor presumido são avaliações presumidas (avaliações que derivam das características sociais e ideológicas de um grupo) - o autor inserido em um meio social contradiz ou reafirma essas avaliações. Desse modo, o julgamento de valor determina "[...] a própria seleção de material verbal e a forma do todo verbal [...]" que caracteriza a obra 
sociais não articuladas - cada palavra está saturada delas. São essas avaliações sociais que organizam a forma como sua expressão direta". No caso do poema, a significação avaliativa se expressa no verso. "O ritmo ou outros elementos formais dos versos abertamente expressam certa atitude ativa em direção do objeto" (BAKHTIN; VOLOSHINOV, [1926] 1976, p. 09).

O segundo modo de inserir o discurso do outro no enunciado é pelo discurso bivocal - em que a separação dos discursos não é nítida - o discurso alheio funde-se, de tal modo que nem sempre é possível dissociá-lo. Contudo, as intenções do discurso são dissociadas. Ocorre pela paródia, estilização, pela polêmica clara ou velada, pelo discurso indireto livre.

A estilização, para Sant'Anna (2003), acontece no plano estilizado, o sentido do discurso vai ao encontro de sentido do texto fonte, há concordância entre os dois planos discursivos. É a imitação de um texto ou estilo: "[...] na estilização as vozes são convergentes na direção do sentido, as duas apresentam a mesma posição significante" (FIORIN, 2006, p.43).

Para perceber a estilização, o conhecimento textual prévio é essencial. Observamos o poema de Drummond, Nova canção do exílio: "Um sabiá/ na palmeira, longe. / Estas aves cantam/ um outro canto. [...]"

O poema de Drummond dialoga com a Canção do exílio, de Gonçalves Dias: "Minha terra tem palmeiras, /Onde canta o Sabiá; /As aves que aqui gorjeiam, /Não gorjeiam como lá. [...]". Por meio da estilização, retomam-se termos como "sabiá" e "palmeira". Há a similitude das palavras "longe" e "lá", há a indeterminação - de qual sabiá? Em que palmeira? Longe onde? Ocorre, ainda, a diferenciação dos termos, quando Drummond diz: "estas aves cantam um outro canto". Claramente, o poeta modernista não se refere ao "sabiá" de Gonçalves Dias, que está longe (FIORIN, 2006, p. 45).

Existe uma intenção em cada um dos textos, caso contrário, não teríamos uma estilização, mas a mera paráfrase. A intenção de cada autor é nítida. Para Drummond, a realidade vivida desaponta, está desenganada, não possui o encantamento presente no poema do período romântico. Já no poema de Gonçalves Dias, o sentimento nacionalista reverbera, causa orgulho ao eu lírico. "No poema gonçalino, quer-se desfrutar dos primores que se encontram na pátria. No 
drummondiano, deseja-se retornar para onde tudo é belo e fantástico" (FIORIN, 2006, p. 46).

A Canção do exílio de Gonçalves Dias, texto-matriz, foi escrito no primeiro momento da era romântica, devido à ruptura entre o Brasil-colônia e Portugal, serviu de inspiração não só a Drummond, mas a muitos outros poetas ${ }^{15}$, ora na forma de alusão, ora de paráfrase, ora de paródia (MENEZES, 1988).

A paródia para Sant Anna (2003) é o uso do discurso alheio, com a intenção de discordar. Para Fiorin (2006), uma imitação que tenciona desqualificar. O autor cita o poema Kipling revisitado, de José Paulo Paes, que se refere ao poeta Rudyard Kipling, autor do poema Se (original If). O poeta usa a condicionante "se" em todos os versos, com exceção dos dois últimos. "Se és capaz de pensar - sem que a isso só te atires, / De sonhar - sem fazer dos sonhos teus senhores. / Se encontrando a desgraça e o triunfo conseguires / Tratar da mesma forma a esses dois impostores", o poema foi escrito ao filho para norteá-lo ao percurso à vida adulta.

O poema de Paes repete em sete estrofes a condicionante "se" acompanhada da abreviação "etc". Em um tom humorado e irônico (característico da paródia) o autor substitui a palavra "homem" por "teorema", finalizando o poema "[...] serás um teorema / meu filho". Ou seja, nitidamente desqualifica a ideia do poema original em que a condicionante "se" assemelha-se a uma demonstração lógica de um teorema. "Paes nega a universalidade expressa pelo poema de Kipling, relativizando-a, o que implica que a direção de sentido do poema parodiante é contrária ao do parodiado" (FIORIN, 2006, p. 43).

O terceiro conceito de dialogismo - refere-se à subjetividade - o processo de construção sócio histórico do ser humano. Nesse processo, socialmente, há alguns discursos que ecoam com voz de autoridade, são centrípetos impermeáveis, não se impregnam de outras vozes. Há, também, as vozes permeáveis aos outros discursos, denominadas centrífugas, que possibilitam "[...] a hibridização, e abrem-se incessantemente a mudança" (FIORIN, 2006, p.56).

O conceito de dialogismo não se refere ao diálogo face a face entre os

\footnotetext{
${ }^{15}$ Ulisses Infante, no texto, As Canções do Exílio (1993), evidencia o diálogo entre o poema matriz (Gonçalves Dias) aos textos de Tom Jobim e Chico Buarque, na música O sábia, ao poema de José Paulo Paes, Canção de exílio facilitada e Eduardo Paulo da Costa, Outra canção do exílio, menciona, também, o texto de Jô Soares, Canção do exílio às avessas, além dos textos de Mário Quintana, Casimiro de Abreu e Murilo Mendes, dentre outros.
} 
interlocutores, mas entre os discursos, deste modo: "[...] o interlocutor só existe enquanto discurso [...]". Assim, as formas de dialogismo estabelecem entre leitor e texto condições para que, a partir das interpretações, se estabeleçam novos discursos. Possibilita, também, que a interação ocorra entre os textos, pois os discursos ali impregnados conversam entre si, criando novos discursos (FIORIN, 2006, p. 166).

A intertextualidade ocorre somente nas relações dialógicas materializadas no texto - dentro dos e entre os textos. O dialogismo dá-se, então, de forma intertextual ou intratextual. Essas formas de diálogo que se estabelecem nos discursos poderiam ser denominadas de um "[...] tipo composicional de dialogismo aquele em que há no interior do texto o encontro de duas materialidades linguísticas, de dois textos" (FIORIN, 2006, p.52-53).

A relação intertextual se dá por paráfrase ou apropriação. A paráfrase é a reescrita ou a transcrição de um discurso alheio, é a reformulação do discurso de outro. É, também, uma criação dialógica, pois mantém a ideia original por meio de uma nova estilização. A apropriação é o aproveitamento do texto-matriz fora de seu contexto, utilizado para suprir outros discursos, criando novos enunciados (SANT' ANNA, 2003, p.46).

Ao transpor os conceitos de dialogia para o mundo literário, notoriamente, compreendemos sua relação intrínseca ao processo sócio histórico construído em cada sociedade, em âmbito local e global. "[...] A literatura fala do mundo, da própria literatura [...]", de modo peculiar e com estilo, registra as vozes do eu e dos outros, "[...] além de poder ser uma ressignificação do mundo, também se compreende dentro de um grande diálogo intertextual" (GUIZZO, 2010, p.105).

\subsection{POEMA}

Os gêneros literários diferem, em alguns aspectos, dos demais gêneros textuais apresentados em sala de aula. Logo, o modo de estudá-los também deve ser específico, sobretudo no caso do poema que traz em seu bojo características únicas. Uma dessas características é o modo de manusear o código linguístico. As palavras, notadas como signos com várias possibilidades combinatórias entre elas, revelam a intenção do poeta, assim, o poema tende a criar "[...] seu próprio código, 
do qual é a única mensagem" (LEVIN ${ }^{16}, 1975$, p. 67).

A conotação presente nos poemas é caracterizada pelo uso de palavras ou expressões que ganham novo significado, conforme a posição, a situação ou o contexto em que se encontram. Conferem à linguagem a expressão artística, que amplia o sentido das palavras, acrescentando-lhes outros significados. A conotação e o enlace de significados são possíveis quando, no texto, há dois planos. No plano semântico, o primeiro deles, para cada significante há somente um significado. No plano das associações entre palavras, o segundo plano, para cada significante surgem outros significantes decorrentes das combinações sugeridas pela composição do poema. Esses novos significantes "[...] mantêm a correspondência sensorial e as afinidades intralinguísticas [...] que obedecem às possibilidades várias de associação" (BOSI, 2000, p. 244).

A combinação e seleção do código linguístico ocorrem, dessa forma, por outros critérios, um dos quais, o sonoro. "[...] Como resultado, o texto literário adquire certo grau de tensão ou ambiguidade, produzindo mais de um sentido, daí a plurissignificação do texto literário". Os múltiplos significados do texto permitem espaço para a atribuição de mais de um sentido ao poema, logo cabe ao leitor "ler, reler, analisar e interpretar" (GOLDSTEIN, 2006, p. 05).

A palavra no poema apresenta-se:

[...] como uma sucessão temporal de sons (significante) vinculada a um conteúdo espiritual (significado). [...] Significante não é apenas a imagem acústica, mas o som físico também; e o significado não é um mero conceito, mas uma complexa carga psíquica que pode incluir emoção, afetividade, volição, intencionalidade, imaginação (MARTINS, 2008, p. 25).

O significante tem seus elementos interligados e se relaciona por numerosos nexos verticais e horizontais. Como significantes totais, tem-se a obra, 0 poema, a estrofe, o verso e o vocábulo. Como significantes parciais, tem-se o ritmo, a entonação, a sílaba e o acento. "[...] o significado total é a representação da realidade e os significados parciais são os múltiplos elementos sensoriais, afetivos e

\footnotetext{
${ }^{16}$ Levin (1975) aplica o princípio da função poética de Jakobson, descrevendo as estruturas linguísticas que distinguem a linguagem poética da comum. Ele estrutura o poema em acoplamentos com duas formas equivalentes, em função de associações que apresentam: entre o som e o sentido; entre a escolha lexical e o sentido; entre a função sintática e o sentido; entre a situação posicional e o sentido.
} 
conceptuais que essa representação comporta" (MARTINS, 2008, p. 26).

Os jogos sonoros são muito explorados nos poemas infanto-juvenis e, isso ocorre porque "[...] figuras como a rima, a aliteração e a paronomásia não têm outro alvo, senão remotivar, de modos diversos, o som de que é feito o signo" (BOSI, 2000, p. 51).

No poema encontra-se, ainda, a expressividade dos fonemas que ocorrem por meio da aliteração, assonância e paronomásia reforçando "[...] os liames entre dois ou mais termos [...]". O que contribui para a unidade textual, mas não só, pode servir, também, como "[...] um processo lúdico que cria harmonia e é agradável ao ouvido" (MARTINS, 2008, p.59).

Dessa forma, a organização do som configura-se, também, um meio para a análise textual, "[...] nas figuras de harmonia, ritmo e métrica encontra-se o processo de sonorização do tema [...]", por isso de extrema importância (GEBARA, 2002, p.31).

Além do som, representativo no gênero textual, a intenção imitativa do poema merece destaque, o efeito que as onomatopeias e o caráter expressivo das interjeições causam no leitor, é um aspecto singular. Além disso, há "o poder sinestésico de certas palavras", que por sua qualidade sonora causam efeitos de "[...] maciez ou estridência; de clareza ou negrume; de visgo ou sequidão [...]". A expressividade impõe-se, principalmente, na leitura poética, pelos efeitos sensoriais valorizados pela repetição dos fonemas ou seu contraste (BOSI, 2000, p.50).

O poema configura-se, também, pelas escolhas sintáticas. Em relação aos textos destinados ao público jovem, a maioria reproduz em seus versos a ordem direta, "[...] aceitando inversões apenas por coesão do ritmo ou rima [...]; os nexos sintáticos são fracos, com supremacia da parataxe". As orações declarativas são uma opção comum entre os poetas, seguida das orações interrogativas e imperativas. Os poemas escritos para o público entre dez e doze anos obedecem às seguintes características textuais (BORDINI, 2008):

Rima ou verso branco; verso livre; ritmo livre e semântico; presença de narrativas; lirismo subjetivo; lírica descritiva; lírica reflexiva; lírica social; heróis aventurescos ou derivados dos gêneros de massa; heróis-crianças comuns; heróis-adultos incomuns; comicidade; temas amorosos, lendários, urbanos, desportivos. As habilidades linguísticas requeridas são: relacionamento linguagem-ficção-mundo; interpretação da linguagem figurada. E as operações intelectuais 
pressupostas: capacidade de análise descritiva; pensamento formal; formação de esquemas conceituais; formação de esquemas de valores próprios (BORDINI, 2008, p. 31).

Neste contexto, "[...] o núcleo poético é posto em evidência não só pelo encadeamento sucessivo dos versos, mas por um sistema de relações e equilíbrios entre quaisquer partes do poema". O encadeamento textual feito por meio de processo criativo, demanda do leitor uma leitura não linear, a percepção vertical propõe a leitura plural, imagética e lúdica do poema (CAMPOS et al, 2006, p. 72).

O caráter singular do poema permite múltiplas leituras e exige do leitor múltiplos olhares. O texto poético, comumente, não segue a leitura linear (como a maioria dos gêneros), sua leitura se faz de forma específica, geralmente, há um destaque maior para o significante (por produzir efeito de sentido) e a sonoridade. Em alguns textos, a leitura vertical se sobrepõe à leitura linear horizontal, "[...] tornando-se uma espécie de leitura em rede e ampliando a significação do texto" (GOLDSTEIN, 2007, p. 366).

\subsection{O GÊNERO POEMA NA ESCOLA}

Embora faça parte dos documentos oficiais, a poesia e os demais gêneros literários, por vezes, sucumbem em sala de aula. Os professores nem sempre conseguem propor leituras que façam sentido ao aluno, de modo que thes desperte 0 interesse. Alguns docentes se sentem tolhidos em trabalhar com 0 poema, deixando-o à margem, por não saber exatamente o que fazer com esse gênero textual.

É preciso estabelecer abordagens que trabalhem com os gêneros, revendo as que já existem e inserindo novos caminhos para romper com as posturas que, comumente, afastam os gêneros literários, sobretudo, o poema, das práticas educativas. As atividades, em aula, necessitam conduzir o estudante a entender o sentido do texto por meio da síntese interpretativa que a leitura estabelece. Assim, ensinar poesia "[...] é trabalhar o texto como resposta a uma necessidade, a alguém (o leitor), a um tempo definido". Apresentar o gênero como instrumento de resposta aos anseios dos estudantes; permite que a poesia seja "[...] um modo de viver o mundo (ver, sentir, experimentar e projetar) e cada composição poética reflete quem 
somos, o que pensamos, sentimos e buscamos" (GEBARA, 2011, p. 10).

O trabalho com poemas suscita muitos questionamentos que acompanham o delinear do esboço da aula:

Como trabalhar com gêneros literários que não parecem fazer parte do cotidiano? Como torná-los significativos para nossos alunos? Como trabalhar com autoria em gêneros que exigem domínio da tradição e uma busca pela inovação, recorte, matéria linguística e temática de forma singular? (GEBARA, 2011, p.10).

Esses questionamentos são importantes e pertinentes para o professor definir qual tipo de aula pretende planejar. O preparo tem que ser feito com segurança e respaldo em teorias e indicações metodológicas que o auxiliarão nesse constructo. $O$ ato educativo não é um fenômeno isolado, exige práticas para despertar o real interesse da criança em aprender.

Em planos de aula bem definidos, há espaço para trilhar vários caminhos, inclusive optar ou não, pelo uso do livro didático, pois a sala de aula exige movimento e dinâmica. Cabe ressaltar que os poemas impressos nos materiais didáticos podem ser utilizados, já que se pressupõe que todos os alunos terão acesso a eles, porém o docente não deve restringir-se somente aos exercícios do livro, é valioso explorar o poema via diferentes tipos de leitura e estratégias. Limitarse ao material simplifica a potencial riqueza que o poema traz às aulas.

Apresentar um poema para que, simplesmente, o estudante circule os substantivos e grife os adjetivos, por exemplo, é, no mínimo, tirar-lhe a oportunidade de explorar o texto e aprimorar suas habilidades de escrita e leitura. Também, é privá-lo de adentrar o mundo da fantasia e da imaginação pelos sons, ritmos e junção de palavras, engenhosamente criadas pelo autor (SORRENTI, 2009).

O primordial em aula é "[...] dizer e ouvir poemas e participar com o poeta na identificação do material poético". Os comentários, a exposição aos textos e as análises dos estudantes será o ponto de partida para o professor intermediar, em primeira instância, o contato entre aluno e poema (SORRENTI, 2009, p.18).

A aprendizagem em espiral ${ }^{17}$, também, aplica-se ao gênero poema com gradual aprofundamento, a cada retomada. $O$ início do trabalho com poemas é feito pelo levantamento prévio do conhecimento dos estudantes; em seguida, sugere-se

\footnotetext{
17 cf Rojo e Cordeiro, 2004. Capítulo I, item 1.2 - As propostas curriculares no ensino de Língua Portuguesa.
} 
apresentar textos com características conhecidas, para, posteriormente, introduzir novos modos da composição do gênero. A aprendizagem em espiral suscita que sejam estabelecidos paralelos constantes entre leituras recentes (novas) e leituras anteriores (antigas). Esse paralelo constante permitirá, ao alunado, perceber as semelhanças e diferenças entre os tipos de textos poéticos, retomando e aprofundando seus conhecimentos em relação ao gênero (GOLDSTEIN, 2007).

Nas aulas seguintes, ao retomar o gênero, convém relembrar ao alunado que a leitura do gênero, por vezes, exige uma leitura em rede, para que o leitor consiga construir relações de sentido: i) entre palavras e sons; ii) entre construções sintáticas do mesmo tipo e que exercem a mesma função. "[...] É preciso que o leitor busque elos de significação em diferentes direções, no interior do texto" (GOLDSTEIN, 2007, p. 367).

Ler poema (e outros gêneros) não é um simples ato de decodificação. A leitura de modo geral é um ato eminentemente cultural ${ }^{18}$, que promove produção de significados. Logo, a leitura de poemas não se resume à simples observação dos jogos de palavras, mas envolve análises que refletem a construção do texto como um todo fundamentado na "[...] experiência particular da vida e da língua, [...] na possibilidade de o leitor reconhecer também a si mesmo no interior da expressão subjetiva" (VILLAÇA, 1994, p. 95).

A leitura atenta e orientada pelo professor volta a atenção do leitor para uma série de elementos que compõem o texto, tais como:

[...] a sequência de palavras, o som e o ritmo que elas trazem [...] os contextos de uso dessas palavras, as sugestões conscientes ou não que elas promovem, os usos das estruturas tanto no âmbito comum quanto no literário, chegando até aos implícitos relacionados às sensações, às ideias, ao sentido e aos sentimentos" (GEBARA, 2011, p. 26).

A leitura, neste preâmbulo, possui propósitos bem definidos que atuam

\footnotetext{
18 Não nascemos leitores. A formação leitora é para toda a vida. Não à toa muitos autores, dentre eles Petit (2013) e Rouxel et al (2004) afirmam, categoricamente, que a leitura é intrínseca a formação humana, isso porque, quanto mais lemos, mais opções temos para retirar do mundo, além disso, a leitura pode ser fonte de conhecimento e lazer.

A leitura é uma prática social, refletida, sentida, fruída, que precisa ser internalizada e fazer sentido. Quanto mais experiências significativas o aluno tiver com a leitura, mais chances ele terá de ser um leitor autônomo, mais chance terá de gostar do ato de ler (BARBOSA; ROVAI, 2012).
} 
para aprofundar os conhecimentos da criança. A mediação docente conduzirá a criança para o desenvolvimento da autonomia leitora e escritora. A literatura, nessa circunstância, é muito mais que um texto, é um instrumento que pode oferecer experiências bem-sucedidas no mundo da leitura e escrita (GEBARA, 2002).

[...] pensar no trabalho com o texto como uma busca, um diálogo em que as estruturas textuais surjam como elementos constitutivos de interação. Essa escolha vai ao encontro de algumas das principais preocupações do professor de língua materna: reunir em uma só atividade a compreensão da trama textual e dos aspectos discursivos do texto, levantando processos linguísticos apontados no conteúdo programático (GEBARA, 2002, p. 13).

Neste contexto, o poema insere-se perfeitamente na escola, pois apresenta a língua ampliando seus limites, em uma "[...] constante recriação artística em que a palavra deixa de ser estatizada, a carga semântica é carregada de possibilidades para diversos trabalhos pedagógicos [...]", superando a mera decodificação. A leitura de poemas insere a criança "[...] num mundo criado pelo texto, mas também um perambular pelos processos linguísticos que o constituem" (GEBARA, 2002, p. 14).

O desenvolvimento da leitura e escrita requer o uso de atividades que proporcionem, além da reflexão crítica, o encantamento pela fruição, pelo estético e pelas expressões artísticas que se delineiam de formas variadas nos textos poéticos. Reconhecer as especificidades dos textos para envolver-se com a leitura de forma prazerosa e, por vezes, lúdica auxiliará a criança a extrair conhecimento, além de sentir emoções e sensações que os jogos de palavras, o ritmo e o som causam ao leitor. Inserir o alunado, nessas experiências, por meio do diálogo, dando-lhe voz contribui para aguçar sua percepção em relação ao texto e, ao mesmo tempo aprender os processos linguísticos da língua materna. 


\section{APRESENTAÇÃO DA PROPOSTA DIDÁTICA APLICADA EM AULA}

Este capítulo apresenta a pesquisa desenvolvida, bem como seus objetivos. Descreve os participantes e os procedimentos de análise utilizados para o desenvolvimento da investigação.

A proposta didática, para o sexto ano, surgiu da necessidade em manter 0 estudante em contato com a leitura literária. No Fundamental I, esse contato é constante por meio de empréstimo de livros; 'contação de histórias'; leituras realizadas, em sala de aula, que incentivam o pequeno leitor a ler por prazer. $\mathrm{Na}$ escola em que leciono, há, em cada sala de aula, uma estante com livros à disposição. O estudante, no Fundamental I, ao terminar as atividades, pega um livro para ler, enquanto aguarda os próximos passos da aula.

No Fundamental II, ocorre uma ruptura com os hábitos cultivados anteriormente: as rodas de leitura, a leitura silenciosa após as tarefas, a escolha de livros para ler em casa e na escola saem de cena. $O$ interesse pelos livros dispostos, na estante, é substituído ao longo do ano, por outras atividades (brincadeiras e conversas paralelas, após o término das tarefas).

Isto posto, optei por uma proposta didática que retomasse os hábitos do fundamental I em relação à leitura. No decorrer da proposta, os livros ficaram dispostos na estante, juntamente, com uma pasta contendo textos do gênero poema. Os estudantes eram incentivados a ler e, caso quisessem, podiam compartilhar suas leituras, após as tarefas, ou antes, de iniciá-las.

Conquanto, o produto final consista em uma produção escrita, a leitura esteve presente em quase todas as etapas, por corroborar com a prerrogativa de que "[...] existe uma conexão profunda entre leitura e escrita quando o objetivo é aprender". Apresentar, por meio da leitura, o gênero poema e deixar o aluno se familiarizar com ele, foi importante para lhe dar suporte em suas produções de escrita (SOLÉ, 2016).

O primeiro passo, em relação à escrita, antecede a proposta que será descrita neste capítulo. Ao longo dos dois primeiros trimestres, tentei mostrar às crianças a 'força' da escrita no que tange sua utilidade e suas diferentes funções (ela serve para quase todas as situações); o poder que dá um domínio suficiente da escrita; o prazer que ela pode proporcionar (a quem produz e a quem lê). Tentei, nas 
aulas, com atividades de escrita, demonstrar que ela não precisa ser sinônima de uma tarefa enfadonha. Para isso, as atividades ora eram realizadas de forma coletiva ora individual, sempre com propósitos, previamente esclarecidos e com público estabelecido (JOLIBERT, 2009).

A proposta didática foi apresentada para as crianças no mês de setembro, para atender o planejamento curricular da secretaria de educação de São Caetano do Sul, que prevê o ensino do gênero poema no terceiro trimestre (OCSCS, 2014, p.184-186).

\subsection{OBJETIVOS}

A proposta didática tem como objetivos:

- Desenvolver a competência leitora e escritora dos alunos.

- Despertar a imaginação e motivar a criação de poemas.

- Ampliar o repertório textual em relação ao gênero poema.

- Levar o aluno a perceber que, no poema, além da leitura linear, também ocorre à leitura vertical, pela associação de termos que apresentam características comuns - sonoridade, classe gramatical, posição no verso ${ }^{19}$.

\subsection{METODOLOGIA}

Dados os objetivos de ensino que privilegiam o desenvolvimento das habilidades de escrita, elaborei uma pesquisa etnográfica, na qual a coleta de dados deu-se por meio de: observação; análise de documentos; interação entre pesquisador e pesquisado/ pesquisador e objeto. O produto final (produções textuais) é apresentado em anexo a este trabalho, dado que constitui o corpus para análise (GIL, 2008).

A pesquisa etnográfica possibilitou intervenções no processo de pesquisa, flexibilizando as atividades. Quando necessário, ocorreram intervenções da pesquisadora. Cabe observar que a pesquisa enfatiza o processo e não somente o

${ }^{19}$ cf Goldstein (2006 e 2007). 
resultado final. Ela relata a proposta didática e efetua a análise dos textos poéticos produzidos pelo corpo discente, com o intuito de verificar o desenvolvimento de habilidades de escrita, particularmente de poemas (GIL, 2008).

A proposta didática materializa-se na aplicação da sequência didática proposta por Dolz, Noverraz e Schneuwly (2004) e inspira-se, também, nos estudos de Jolibert (2009). Procurei estabelecer uma abordagem qualitativa da pesquisa, eleita por permitir uma coleta de dados abrangente e coerente com os objetivos deste trabalho.

\subsection{PERFIL DA SALA DE AULA - CONTEXTO DA APLICAÇÃO DA PROPOSTA DIDÁTICA}

A proposta didática foi aplicada em uma escola municipal de Ensino Fundamental I e II, localizada na cidade de São Caetano do Sul, direcionada a alunos do sexto ano, entre onze e doze anos, que estudam no período matutino. A turma é composta por vinte e seis crianças. Elas, muitas vezes, se dispersam, brincam bastante em aula. Algumas levam carrinhos e figurinhas para brincar. Dessa forma, as aulas precisam ser interativas e dinâmicas para atrair e prender a atenção dos alunos.

O planejamento pedagógico do Fundamental I contempla o trabalho com poemas nos anos inicias (período de alfabetização). Lê-se poemas, adivinhações, parlendas, quadrinhas e trava-línguas conforme o planejamento proposto nas OCSCS (2016, p. 55). As professoras, do primeiro ano, confecionam murais e cartazes com esses gêneros.

Há, também, na escola o projeto "Caderno de poemas". Cada criança confecciona um caderno para colar alguns poemas de Vinícius de Moraes e Cecília Meireles. Esse projeto é direcionado aos alunos do segundo ano, no primeiro trimestre. Após a leitura feita pelo professor, as crianças desenham no caderno, completando o poema. Dessa forma, ao iniciar o Fundamental II, espera-se que a criança já tenha alguns conhecimentos prévios sobre o gênero poema.

Importante mencionar a trajetória curricular e os trabalhos realizados no Fundamental I porque os alunos do sexto ano, que integram esta pesquisa, estudam na instituição desde os seis anos. 
Apesar de a escola se esforçar para integrar a leitura e a escrita ao quotidiano do estudante, percebo lacunas na aprendizagem. As crianças do sexto ano apresentam dificuldades em interpretar e produzir textos de um modo geral. A maioria efetua a formulação de um texto de modo superficial, sem explorar plenamente as possibilidades de escrita.

\subsection{O CARÁTER LÚDICO NA PROPOSTA DIDÁTICA}

De acordo com as características da turma, apresentada no item anterior, em toda a sequência esteve presentes aspectos lúdicos e dinâmicos para aproximálos do gênero em estudo.

O brincar e jogar faz parte do desenvolvimento da criança. O sexto ano, eleito para a aplicação da proposta didática, brinca o tempo todo (levam para a escola carrinhos pequenos, cards, mochila em forma de urso, estojos em forma de carrinhos, robôs etc.). Por conseguinte, a proposta didática contempla o brincar como mecanismo informativo porque, nesta interação, espera-se que eles aprendam as características do objeto em estudo (o poema).

Na perspectiva da criança, o lúdico provoca prazer e sensação de bemestar, o estudante participa da proposta didática sem, eventualmente, pensar nas "[...] consequências positivas ou preparadoras de alguma outra coisa". Ao planejar as atividades, o brincar, os objetivos, os meios e os resultados tornam-se indissociáveis e "[...] enredam a criança em uma atividade gostosa por si mesma, pelo que proporciona no momento de sua realização" (MACEDO; PETTY; PASSOS, 2007, p. 14).

Assim, a dimensão lúdica, nos processos de aprendizagem, apresenta as seguintes qualidades: i) prazer funcional; ii) desafios iii) possibilidades; iv) dimensão simbólica; v) modo construtivo ou relacional. Esse grupo de qualidades proporciona o "caráter autotélico do brincar", estimula o desenvolvimento autônomo na aprendizagem. $\mathrm{O}$ alunado aprende consigo mesmo e com os demais envolvidos nas brincadeiras, porque "organizam-se para resolver os desafios, criam conflitos e projeções, concebem diálogos, praticam argumentações, resolvem ou possibilitam o enfrentamento de problemas" (MACEDO; PETTY; PASSOS, 2007, p. 14). 
O brincar é sério, uma vez que supõe atenção e concentração. Atenção no sentido de que envolve muitos aspectos interrelacionados, e concentração no sentido de que requer foco, mesmo que fugidio, para motivar as brincadeiras. O brincar supõe também disponibilidade, já que as coisas mais importantes da vida da criança - o espaço, o tempo, seu corpo, seus conhecimentos, suas relações com pessoas, objetos e atividades - são oferecidas a uma situação na qual ela, quase sempre, é a única protagonista, a responsável pelas fantasias que compõem essa atividade. Para adolescentes, adultos e idosos, o brincar continua com a mesma função [...] (MACEDO; PETTY; PASSOS, 2007, p. 14).

Por intermédio dos processos lúdicos, a proposta didática buscou contemplar o aspecto desafiador das atividades para aguçar a curiosidade e o interesse da turma. Os jogos utilizados (descritos adiante), em algumas etapas da sequência, tiveram por objetivo promover "desafios e possibilidades" para solucionar situações-problema de formas diferentes, contribuindo para a aquisição de conhecimento a partir daquilo que o aluno já sabe.

As atividades privilegiaram dois aspectos cognitivos importantes: a observação e a regulação, ou seja, a atenção ao objeto estudado e a antecipação de ações para corrigir ou evitar erros. Neste sentido, quando feito em grupo "o trabalho com jogos oferece um rico arsenal de possibilidades, contribuindo para a construção de relações sociais cuja direção é aprender a considerar limites e agir de forma respeitosa com as pessoas" (MACEDO; PETTY; PASSOS, 2007, p. 14).

Nas etapas, em que não houve brincadeiras ou jogos explícitos, a ludicidade expressou-se mediante a leitura de alguns poemas. Não foram raros os momentos em que as crianças riram, ao tentar reproduzir sons e ritmos dos textos lidos. A leitura em voz alta, individual ou em grupo, possibilitou à turma conhecer as características do gênero literário: as crianças experimentaram e sentiram emoções e construíram significados. O entendimento textual, neste contexto, deu-se nas relações entre texto e o conhecimento do estudante (ROSENBLATT, 1994).

\subsection{DAS ATIVIDADES PROPOSTAS E DA PROPOSTA DE JOLIBERT}

A sequência didática, dentre outros teóricos, tem como base os estudos realizados por Jolibert (2009, p.195), por isso as atividades visam a apresentar o gênero poema "[...] em primeiro lugar de maneira concreta, como algo que está ao 
alcance do ouvido, da mão e do olhar, [...]”; em segundo lugar, permitir que a criança apreenda as particularidades do gênero.

Para isso, a sequência didática (denominada pela autora de "canteiros") seguiu os seguintes princípios: i) projeto de escrita; ii) parâmetros da situação de produção; iii) produção individual20; iv) confrontações para resgatar as características globais de um tipo de texto; v) reescritas; vi) atividades de sistematização linguística e; vii) produção final.

Para desenvolver a competência leitora e escritora de textos poéticos, faz-se necessário, também, desbloquear a imaginação e estruturá-la por meio da escrita, incentivar a invenção e o uso de palavras, que contribuam para explorar o real e o imaginário. A criatividade da criança deve ser cultivada em todas as situações por intermédio de jogos e brincadeiras que provoca a intervenção criativa. O poema, em aula, é instrumento para aguçar a curiosidade e a ação criativa, despertando o ensejo de escrever e entender poemas (JOLIBERT, 2009).

\begin{abstract}
É lendo que nos tornamos leitores e não, aprendendo primeiro para poder ler depois [...]. Colocada numa situação de vida real em que precisa ler um texto, ou seja, construir seu significado (para sua informação ou prazer), cada criança mobiliza suas competências anteriores e deve elaborar novas estratégias para concluir a tarefa (JOLIBERT, 2009, p.14)
\end{abstract}

As atividades fundamentam-se na percepção, discussão e criação. As atividades que envolvem a percepção visam a despertar sensorialmente o aluno para a leitura / audição de poemas em seus aspectos fônico, semântico, sintático e pragmático. A percepção sensorial é importante para a internalização e criação do gênero poema. As leituras privilegiam momentos em que as crianças podem "[...] dizer um poema que escolheram e apreciaram, para tentar partilhar a emoção sentida; transmitir para seus colegas os textos dos quais mais gostaram; ler poemas em silêncio e para si” (JOLIBERT, 2009, p. 209).

Em relação às leituras de poemas, as atividades, ao longo da sequência, propiciaram três momentos, com base nas atividades propostas por Sorrenti (2009, p. 101-105):

i) Ouvir ou ler sem compromisso (criei oportunidades para que os alunos

${ }^{20}$ Optei pela produção em grupo e, na sequência, produção individual. 
pudessem ouvir ou ler poemas por prazer) por meio da própria voz, da voz do colega, da voz do professor. Em algumas etapas, ouviram poemas em áudio.

ii) Ler em silêncio, tentar entender o texto antes de compartilhá-lo. Leitura feita no ritmo individual, na qual cada estudante teve a oportunidade de escolher o poema.

iii) Leitura rítmica, exploramos o aspecto rítmico do poema, com o auxílio do próprio corpo (bater as palmas, as mãos nos braços, estalar os dedos, bater os pés etc.).

Cada um desses momentos permite ao estudante participar das aulas como protagonista do processo de aprendizagem. A exposição às leituras, por intermédio da caixinha de poemas, livros e pasta de poemas (descritos adiante), além das atividades, foi constantemente incentivada para propiciar o contato com o gênero.

Nos momentos de discussão, efetuamos atividades que dão a vez e a voz ao estudante para extrair da sala o máximo de leituras possíveis. A finalidade desses momentos foi ora despertar o imaginário do grupo, ora propiciar a reflexão acerca dos poemas para que os alunos percebessem "[...] os aspectos formais (rimas, repetições sonoras, ritmo etc.) para a compreensão do poema", além das estruturas do gênero (enunciativas; sintáxicas; léxico-semânticas; gráficas e espaciais) (SOUZA, 2013, p. 85).

A discussão, na maioria das atividades, foi formada em rodas de conversa por permitir ao aluno expor suas impressões acerca dos textos, ao mesmo tempo em que assumi a postura de mediador para corroborar com aprendizagens significativas.

$\mathrm{Na}$ etapa de criação, os alunos expressaram suas aprendizagens pela produção coletiva e individual. A etapa de reescrita contribuiu para o aprofundamento da elaboração do texto, já que “[...] reescrita não é recópia [...]". As reescritas foram totais ou "[...] parciais, referindo-se a um nível de análise ou a um pedaço do texto [...]", além de assumir um aspecto "[...] que depende muito mais do esquema ou da silhueta que dá escrita no sentido próprio" (JOLIBERT, 2009, p. 47). 


\subsection{RELATO DAS AULAS E ATIVIDADES DESENVOLVIDAS AO LONGO DA PROPOSTA DIDÁTICA}

As atividades tiveram início em setembro de 2016 e seguiram até a primeira quinzena de novembro, com duração de vinte e cinco aulas de 50 minutos cada uma.

Algumas ações se estenderam até o término do ano letivo - deixei disponível um espaço, na sala, com poemas para serem lidos; disponibilizei alguns livros de poesia; busquei incentivar à leitura de poemas no término das atividades, ou antes de seu início.

Ao planejar as atividades, em alguns momentos, utilizei os recursos disponíveis nos Cadernos Virtuais da Olimpíada de Língua Portuguesa - OLP $(2014)^{21}$. A Olimpíada de Língua Portuguesa - Escrevendo o Futuro é um concurso de produção de textos destinado aos alunos do Fundamental II e Ensino Médio. Para cada ano dos respectivos segmentos, aborda-se um gênero textual, o sexto ano participa do concurso com a produção de textos do gênero poema. Além de promover o concurso (que é bienal), a olimpíada visa à formação de educadores por meio de cursos disponibilizados na plataforma on-line e nas revistas publicadas. Nos cadernos virtuais (2014), há explicações e sequências de atividades, além de áudios e o jogo - Arquipélago de poemas ${ }^{22}$, utilizado em minha proposta didática.

\subsubsection{Autores e recursos utilizados}

Para confeccionar a proposta didática utilizei autores do gênero poema. Alguns livros foram selecionados da biblioteca da escola, outras obras foram emprestadas de minha coleção ou emprestadas de colegas. Para organizar as leituras utilizei três recursos: i) os livros; ii) a caixinha de poemas e; iii) a pasta de poemas.

A 'caixinha' de poemas era, literalmente, uma caixa pequena, que foi encapada e decorada para que o estudante colocasse, somente, a mão para retirar

\footnotetext{
${ }^{21}$ Informações disponíveis em <https://www.escrevendoofuturo.org.br/concurso> Acesso em: 10/04/2017.

${ }^{22} \mathrm{O}$ jogo está disponível no caderno virtual - Poema,

<https://www.escrevendoofuturo.org.br/caderno_virtual/caderno/poema/jogo.html> Acesso em: 15/05/2016.
} 
os poemas (um por vez), que foram digitados em pedaços de papel e dobrados. Não era necessário devolver os poemas à caixa, a ideia era compartilhar a leitura com os outros colegas (outras turmas, presenteando-os). A caixinha foi usada até o fim do ano letivo e quando ficava vazia era preenchida com novos poemas. Na caixinha de poemas, havia: limeriques, haicais e quadrinhas.

Os haicais escolhidos são destinados ao público infantil e infanto-juvenil, a maioria dos poemas segue as quatro regras do poema de origem japonesa - 17 sílabas, divididas em três versos - compostos por 5, 7 e 5 sílabas, respectivamente (REZENDE, 2011). Os autores dos poemas de haicais que compuseram a caixinha foram: Clement (2011); Leminski (2012); Rezende (2011); Ruiz e Rezende (2008); Ziraldo (2013).

Coloquei, na caixinha, alguns limeriques destinados ao público infantil e infanto-juvenil, retirados do livro, Limeriques para pinturas - Elias José (2007) e do livro, Limeriques trava-línguas - Viviane Veiga Távora (2013). A princípio, usaria só alguns poemas da autora, porém os alunos gostaram tanto, que decidi colocar todos os poemas do livro. Todos os limeriques escolhidos seguem as regras de confecção: cinco versos; o primeiro, o segundo e o quinto rimam entre si, com oito ou nove sílabas; e o terceiro e o quarto rimam entre si, com cinco ou seis sílabas (CUNHA, 2013).

A caixinha, também, foi composta por várias quadrinhas - poema com quatro versos, muitos de cunho popular, geralmente, com sete sílabas e rimas no segundo e quarto versos (GOLDSTEIN, 2006). As quadrinhas foram retiradas de quatro livros: Quadrinhas - Tatiana Belinky (2014); Quadrinhas brasileiras - Silvio Romero (2016); Histórias, quadrinhas e canções com bichos - vários autores - (org) Heloisa Jahn (2004); Cultura popular no Brasil - Marcos Ayala, Maria Ignez e Maria Ayala (1995) e, também, foram retiradas de alguns sítios on-line ${ }^{23}$.

O poema O relógio, de Vinícius de Moraes (2004); e o poema Ou isto ou aquilo, de Cecília Meireles (2012) compuseram a caixinha de poemas, na primeira aula, com a intenção de lembrá-los dos conhecimentos adquiridos no Fundamental I.

23 Sítios: <http://baudeideiasdaivanise.blogspot.com.br/2009/08/linguagem-36quadrinhas.html>. Acesso em: 29/06/2016.

<https://www.portaleducacao.com.br/conteudo/artigos/pedagogia/educacao-infantilquadrinhas/51392>.Acesso em: 29/06/2016.

< http://www.webartigos.com/artigos/a-trova-popular-ou-quadrinha/53255/>. Acesso em:

29/06/2016. 
Apresentei, também, além da caixinha de poemas, a pasta de poemas, expliquei que ficariam na estante para serem manuseadas e apreciadas. Os poemas que compuseram a pasta, até o término do ano letivo, foram dos seguintes autores: Azevedo (2003, 2012); Cunha (2013a); Marcel e Pedersen (2013); Lisboa (2003); Quintana (2008); Bandeira (2006, 2009, 2013); Paes (1991); Caparelli (2003); Meireles (2012).

Os livros retirados da biblioteca, a cada quinze dias, aproximadamente, eram trocados. Na pasta de poemas, coloquei textos que não constavam no acervo da escola ${ }^{24}$, cada folha foi posta dentro de um plástico - o anverso continha o poema e o nome do autor e o verso as referências com uma breve biografia do poeta.

Após as atividades, ou antes, delas, as crianças realizavam as leituras de modo silencioso (era opcional compartilhar a leitura, efetuando-a em voz alta). Em alguns momentos, eu também, escolhi poemas para ler, seguindo a orientação de que mostrar o meu gosto pela leitura, comentá-lo, indicar títulos, falar sobre autores e compartilhar minhas experiências incentivaria as crianças (SOLÉ, 2016).

\subsubsection{Relato das aulas}

As atividades preocuparam-se com a percepção auditiva do gênero, dessa forma, em todas as aulas, houve leituras e/ou escuta de poemas. Procurei inserir as discussões sobre o gênero em quase todos os momentos, sistematizando as aprendizagens. As atividades de criação foram diversificadas com dois momentos de produção: coletiva e individual.

A proposta de Jolibert (2009), em alguns momentos, alinha-se aos estudos de Dolz, Noverraz e Schneuwly (2004). Assim, o planejamento sequencial das atividades, em primeiro momento, privilegiou apresentar a proposta didática aos estudantes e seus principais objetivos, além de sondar os conhecimentos prévios da turma. Essa etapa, para os autores, confere dois procedimentos fundamentais: o primeiro prioriza a construção comunicativa que deve ser objetiva e clara; o segundo enfatiza os conteúdos que serão priorizados nos módulos para a construção da

\footnotetext{
${ }^{24}$ A biblioteca da escola é pequena e conta com pouquíssimos exemplares sobre o gênero.
} 
produção final. Por conseguinte, privilegiaram-se alguns conteúdos rítmicos do gênero, além dos aspectos sintáticos, semânticos e lexicais.

"[...] Produzir textos escritos e orais é um processo complexo, com vários níveis que funcionam, simultaneamente, na mente de um indivíduo". Por isso, há quatros níveis principais na produção de textos: representação da situação de comunicação - momento de construção "[...] da situação de comunicação e da atividade de linguagem a ser executada"; elaboração dos conteúdos; planejamento do texto; realização do texto (DOLZ; NOVERRAZ; SCHNEUWLY, 2004, p. 104).

Os autores sugerem, ainda, que as atividades sejam diversificadas, realizadas em três categorias: as atividades de observação e de análise de textos; tarefas simplificadas de produção de textos; elaboração de uma linguagem comum. É importante, também, sintetizar as informações para que o estudante tenha meios de consultar o vocabulário técnico e as regras elaboradas durante a aula. $\mathrm{Na}$ sequência, as atividades foram sintetizadas ao fim de cada etapa por meio de esquemas na lousa, elaborados coletivamente e depois copiados nos cadernos.

$\mathrm{Na}$ produção individual, o aluno tem a chance de colocar em prática as aprendizagens vivenciadas em aula, além de avaliar suas habilidades de escrita sobre o gênero. É, também, após a sua reescrita o instrumento de avaliação para o professor. Dolz, Noverraz e Schneuwly (2004) sugerem que este seja feito de modo somativo, ressaltando que os critérios devem ser definidos e esclarecidos aos estudantes desde o início das atividades.

\subsubsection{Ponto de partida - aula 01 a 06}

Solicitei, à coordenação do Fundamental I, informações para verificar qual contato as crianças tiveram com o gênero poema. Constatei que, nos primeiros anos do ensino, elas participaram de dois projetos que envolviam poemas de Cecília Meireles e Vinícius de Moraes.

A partir dessas informações e das OCSCS (2014) iniciei a sequência didática com o intuito de resgatar alguns conhecimentos prévios sobre o gênero (aula 1). Para isso, alguns poemas escolhidos para a caixinha de poemas foram 
retirados do Caderno de poemas ${ }^{25}$ (Cecília Meireles e de Vinícius de Moraes), além de quadrinhas, limeriques e haicais para crianças. Para que todos conseguissem efetuar a leitura e comentá-las na roda, optei por poemas curtos ${ }^{26}$.

Ao escolher os poemas, as crianças fechavam os olhos, davam pulinhos, enquanto os demais vibravam. Seguia-se a leitura do poema selecionado. Todos efetuaram as leituras em voz alta, com exceção de dois alunos que não quiseram fazê-lo.

Após os comentários sobre os poemas lidos, questionei se todos sabiam o que é um poema. Se conheciam algum autor. Se já haviam escrito poema alguma vez etc.

A maioria afirmou conhecer poesia, sem prestar atenção na palavra "poema", alguns arriscaram dizendo que era música; outros disseram ser sentimento; outros, ainda, afirmaram ser um texto escrito em versos. Perguntei o que eram versos - a maioria não soube responder - um aluno, timidamente, disse que eram as linhas da poesia, então, as demais crianças o seguiram, afirmando ser a linha da poesia.

Em relação aos autores, mencionaram Cecília Meireles, Vinícius de Moraes e Manuel Bandeira. Em relação às perguntas feitas por mim, ninguém relacionou aos textos retirados da caixinha de poema.

Nas aulas 2, 3, e 4, os estudantes foram estimulados a realizar leituras dos materiais disponíveis na sala. Para isso, sugeri que poderiam presentear os colegas com poemas da caixinha ou da pasta, caso desejassem e, assim, foi feito, liam em voz alta para presentear alguém ou, simplesmente, entregavam ao colega. A prática estendeu-se a professores, inspetores e colegas de outras turmas.

No início das aulas, ou término das atividades, as crianças liam (leitura silenciosa, individual e autônoma) os poemas disponibilizados na sala. Desse modo, mantivemos, até o fim do ano letivo, essa prática. Não era obrigatório comentar ou presentear os colegas, só o fariam se desejassem compartilhar a leitura.

Ao perceber o interesse das crianças pelos textos dispostos nas aulas, pedi que pesquisassem um poema para apresentar nas aulas subsequentes.

25 Projeto confeccionado no fundamental I, no segundo ano.

${ }^{26}$ Contudo, antes de iniciar a proposta didática, pedi para os alunos responderem em um pedaço de papel (sem identificação) a seguinte pergunta: O que é poema para você? Após responderem, sem minha interferência, os papéis foram colocados em um envelope. 
Nas aulas 5 e 6, a leitura dos poemas foi feita somente pelas crianças, cada uma leu o poema que pesquisou. Percebi problemas de fruição, mas não fiz intervenções, o objetivo era deixá-las à vontade para ler, discutir, analisar o seu poema e dos colegas. Registrei os problemas (a maioria em relação a pontuação; equívocos nas pausas; falta de conhecimento do vocabulário etc.), para abordá-los nas aulas posteriores.

A maioria pesquisou na internet, com exceção de dois alunos: um foi à biblioteca da escola e o outro trouxe o exemplar da escritora Ana Soares Miranda (1981), sua tia e, além de mostrar o exemplar à turma, elegeu o poema Educação para ler em aula:

\section{Educação}

Apesar da pobreza, da delinquência, da tristeza, existe a vontade, o otimismo, a beleza.

Apesar da beleza, do otimismo, da vontade, existe a tristeza, a delinquência, a pobreza (MIRANDA, 1981, p.17).

O aluno A participou ativamente desta aula, orgulhoso de ter na família uma escritora de poemas, arriscou interpretar o texto com comentários sobre seu sentido. Aproveitei para comentar o ritmo do poema, destacando as rimas externas nas palavras "pobreza; tristeza; beleza". Enfatizei, ainda, o título do poema Educação (fundamental para situar o tema do texto e as relações semânticas estabelecidas); e a locução preposicional "apesar de" indicando oposição (porém não impeditiva) aliada às escolhas lexicais que produzem efeitos antagônicos nos conjuntos de palavras "pobreza, delinquência, tristeza"; "vontade, otimismo, beleza". A escolha do verbo "existir" (modo indicativo, terceira pessoa, presente) também, foi abordada. Na análise das crianças, o verbo "existir" produz a certeza de que na educação, ao mesmo tempo em que ocorrem situações que a favorecem, ocorrem outras que a prejudicam. Educação, neste contexto, foi percebida somente no contexto escolar, a discussão não se estendeu a outros lugares nem a uma maior 
abrangência do tema.

A aluna B trouxe da biblioteca um exemplar de Caparelli (2003, p.23) e elegeu o poema: "O Zigue e o Zague/ Não sabiam a direção/ É por aqui? / Por aqui, não! / E sumiram no horizonte, / Sem chegar à conclusão". Discutimos o significado das palavras Zigue e Zague, as crianças recorreram ao dicionário, encontrando a palavra "ziguezague", questionei o porquê de o autor escrever a palavra decompondo-a em duas e com letra maiúscula. Em relação à letra maiúscula, as crianças salientaram que o poeta transformou as palavras em substantivos próprios. Sobre a decomposição, houve alguns equívocos, porém, após alguns questionamentos de intervenção e da análise do que significa ziguezague no dicionário, eles perceberam que a decomposição representa as linhas que fazem o ziguezaguear, formando os ângulos salientes e reentrantes ${ }^{27}$, o poeta dá vida a essas linhas, que não sabem qual direção seguir (HOUAISS, 2011).

Os demais trouxeram poemas pesquisados na internet. Seis alunos trouxeram Cecília Meireles ( $A$ bailarina; Ou isto ou aquilo; $A$ sementinha), cinco escolheram Carlos Drummond de Andrade (Poema da purificação; Para sempre), dois elegeram Vinícius de Moraes ( $A$ casa; Tomara), um aluno trouxe Mário Quintana (Mãe) outro elegeu o poema Amizade (autor desconhecido) e três crianças escolheram Pedro Bandeira (Por enquanto eu sou pequeno; Nome da gente; Quem sou eu?). As respostas, para a escolha dos poemas, foram basicamente duas: ou já conheciam o poeta ou gostaram do poema por causa da sonoridade (a maioria mencionou as rimas externas e a escolha do léxico).

Não propositalmente, na aula, detivemo-nos um pouco mais no texto Quem sou eu? "[...] Eu às vezes não entendo! / As pessoas em um jeito/ De falar de todo mundo/ Que não deve ser direito [...]". O poema gerou discussões sobre o ato de fofocar e a arguição pautou-se no que era mais importante: ser ou ter. Algumas crianças mencionaram o modo subjuntivo ${ }^{28}$, na terceira e quarta estrofe, então, aproveitei para comentar sobre os verbos no pretérito do modo subjuntivo; o uso da condicionante "se" e, nos verbos em primeira pessoa acompanhados dos pronomes pessoais do caso reto (eu) e oblíquo (me), considerando a escolha e a intenção do poeta em usá-los. "[...] eu queria que comigo/ Fosse tudo diferente. / Se alguém

\footnotetext{
${ }^{27}$ Os dicionários ficam disponíveis em uma prateleira dentro da sala de aula.

${ }^{28}$ Conceito gramatical de verbo - modo subjuntivo, indicativo e imperativo cf Castilho, 2016, p. 391-396.
} 
pensasse em mim, / Soubesse que sou gente. / Falasse do que eu penso, / Lembrasse do que eu falo, /Pensasse no que eu faço/ Soubesse porque me calo." (BANDEIRA, 2009, p. 52). Ressaltei os versos em redondilha maior (exceção do verso: Soubesse que sou gente - hexassílabo) e as rimas intercaladas em algumas estrofes.

Em paralelo, estávamos estudando os modos indicativo, subjuntivo e imperativo, por isso, alguns estudantes conseguiram correlacionar a composição do poema com o modo verbal subjuntivo. Acredito que as crianças se sentiram à vontade com as nomenclaturas - substantivo próprio; modo subjuntivo; adjetivo (mais adiante) porque as aulas, de modo geral, contemplam o ensino gramatical com análises que ultrapassam as exemplificações fragmentadas. Acostumados a estudar por meio de textos, conseguiram inferir no poema a intenção do autor em enfatizar um desejo e, assim, correlacionar a nomenclatura.

Os poemas pesquisados foram colocados na pasta de poemas e circularam na sala por uma semana, sendo, posteriormente, substituídos por outros.

\subsubsection{Leitura e discussão de poemas - aulas 7 e 8}

As diversas leituras promovidas, ora em voz alta, de forma compartilhada, ora de forma autônoma e particular, provocaram a necessidade de analisar os poemas de modo mais aprofundado.

A leitura dos poemas, no primeiro momento, foi feita por mim, em seguida pelas crianças (só as que quiseram). Optei por ler, primeiramente, para servir de modelo. Conquanto as aulas anteriores já explorassem as leituras (silenciosa e em voz alta), fiz algumas intervenções, relembrando o uso da pontuação.

Nas aulas 7 e 8, apresentei três poemas. O primeiro poema, Canção de muito longe (QUINTANA, 1987, p.12), gerou discussões sobre como efetuar a leitura do poema, alguns leram devagar, outros mais rápido, alguns cantaram a cantiga original e tentaram, também, cantar o poema. As crianças brincaram com as palavras tentando achar o jeito "certo" de declamar. Comentei, com a turma, que o poema utiliza trechos da canção tradicional para o autor contar à sua moda um tempo que passou e, por isso, faz uso dos verbos no pretérito imperfeito.

Chamei a atenção para a pontuação, sobretudo no primeiro verso (uso do 
hífen); sexto e sétimo verso (uso das reticências). Percebi algumas confusões no uso do hífen, por isso, retomei exemplos em que usamos o hífen para separar palavras, como ocorre no poema; e usei outros exemplos em que ele serve para ligar palavras compostas ou derivadas por prefixação, além de lembrá-los que fazemos uso do hífen para ligar o verbo ao pronome oblíquo átono (CUNHA; CINTRA, 2016).

Abordei, também, o uso do léxico em "[...] $E$ todas as noites, sob o velho céu arqueado de bugigangas/ A mesma canção jubilosa se erguia". E a junção das palavras no verso: "[...] A canoooavirou". A intenção era mostrar a construção composicional do texto e as escolhas do poeta. As crianças não conseguiram inferir - significado das palavras "arqueado, bugigangas, jubilosa" sem a ajuda do dicionário. No dicionário Houaiss (2011), encontraram: "arquear: dobrar (-se) em forma de arco, curvar (-se)" (p. 61); "júbilo: extrema alegria" (p. 443). Em relação às palavras "arqueado e jubilosa" não me surpreendi de a turma recorrer ao dicionário, minha surpresa foi em relação à palavra "bugigangas". Tentei relacioná-la a objetos vendidos no comércio de rua, mas em vão. Recorreram ao dicionário - bugiganga: objeto de pouco valor" (HOUAISS, 2011, p. 115).

$\mathrm{O}$ aluno $\mathrm{H}$, entusiasmado, disse que conseguiu "traduzir" essa parte do texto, para ele o autor, na verdade, queria dizer que o "céu estava curvado em cima de coisas de pouco valor, mas, mesmo assim, estava contente". Outro aluno questionou o que seriam essas "coisas" de pouco valor. A sala, eufórica, levantou algumas hipóteses: nós seríamos "coisas de pouco valor"; os objetos construídos pelo homem; a natureza etc.

Na sequência, lemos o poema Debussy (BANDEIRA, 2009, p.19). jogral estabelecido pela turma rendeu muitas leituras, as crianças gostaram da brincadeira. Decompusemos o poema de algumas maneiras, seguindo as sugestões da sala. A primeira foi em dois grupos - versos descritivos e versos narrativos. Após o jogral, questionei o título Debussy. Apresentei o vídeo do compositor Claude Debussy, músico francês que viveu durante o período de 1862 a $1918^{29}$, comentando sobre o título e a relação entre o compositor e o poema. Novamente, ressaltei a composição do poema, mostrando às crianças a formação do texto em duas vozes, como se fossem mãos do piano. Comentei o uso dos versos descritivos

${ }^{29}$ Disponível em: <https://youtu.be/OUx6ZY60uil> Acesso em: 05/09/2016. 
"Para cá, para lá.../ Para cá, para lá... [...] (Vem e vai...) [...]" e narrativos "[...] Um novelozinho de linha.../ [...] Oscila no ar pela mão de uma criança/ Que delicadamente e quase a adormecer o balança/ - Psiu... - /[...] - O novelozinho caiu". Chamei a atenção para a pontuação - uso das reticências ao longo do poema e o uso do travessão, indicando o diálogo direto no texto.

Como separei a turma em dois grupos, a aluna B, sugeriu dividir a sala em três grupos, para que o terceiro grupo declamasse, somente, "- Psiu..." como uma terceira "personagem". Ela sugeriu que esse grupo, colocasse o dedo indicador na boca, para indicar silêncio e declamasse com a voz "baixinha" (personagem e baixinha são os termos utilizados pela estudante). Assim foi feito.

Dividir a turma em grupos para declamar o poema causou alvoroço: o primeiro grupo quis trocar, posteriormente, com o segundo. Alguns alunos não quiseram dividir a turma em três grupos, afirmando que falar "psiu" era pouco.

$O$ termo narrativo rendeu alguns questionamentos, $O$ aluno $D$ perguntou se nos poemas era possível ter personagens, quando eu respondi que sim, alguns questionaram quem eram as personagens desse poema, não precisei responder, 0 aluno A, respondeu: "um bebê querendo dormir". Outros o corrigiram, dizendo que não era bebê, mas uma criança, a discussão centrou-se, então, na idade da criança. Com algumas intervenções, concluíram que era uma criança pequena, mas não era possível saber se menino ou menina e qual, exatamente, a sua idade.

Em relação aos versos descritivos, a discussão deu-se em quem ou o quê balançava a criança, algumas hipóteses foram levantadas: a criança estava no colo da mãe e ela o ninava; a criança estava em uma rede; em um berço de balanço etc. Percebi que não houve questionamento ou comentários expressivos sobre o título do poema, nem sobre o compositor Claude Debussy. Após a turma ouvir a música, ninguém a relacionou ao poema (ao menos não foram efetuados comentários/perguntas neste sentido - infelizmente, na dinâmica dessa aula, não fiz intervenções que possibilitassem o aprofundamento das relações entre Claude Debussy e o poema - percebi isso, após o término da aula).

O poema, A chuva (ALCOFORADO, 1992, p. 15), permitiu enfatizar o uso de onomatopeias e do léxico usado para compor o texto, bem como o jogo sonoro para lembrar o cair da chuva em um telhado, assim como a posição do poema na folha que forma a imagem que lembra, também, o cair da chuva.

Curiosamente, o aluno F perguntou se "psiu" (termo abordado no poema 
anterior) era uma onomatopeia. Fiquei surpresa com essa pergunta por dois motivos: primeiro, o aluno F, quase não participa das aulas, inclusive relaciona-se pouco com a turma; segundo, ele relacionou o conteúdo (texto) da aula anterior às explicações sobre onomatopeias. Respondi a ele que sim, que poderia indicar silêncio ou chamamento (CUNHA; CINTRA, 2016).

No decorrer da aula, enquanto observávamos as rimas do poema, o aluno $E$, afirmou que o texto poderia ser decomposto em dois, (acredito que por influência da aula anterior), um referindo-se à chuva, propriamente, e o outro sobre a dança efetuada por ela, o estudante executou a seguinte leitura:

\begin{tabular}{|l|l|}
\hline \multicolumn{1}{|c|}{ Texto 1 } & \multicolumn{1}{c|}{ Texto 2 } \\
\hline A chuva & sobre o telhado \\
\hline Executa & um leve \\
\hline gota a gota & Sapateado \\
\hline plict-plic & Macio \\
\hline plict-ploc & molhado \\
\hline
\end{tabular}

As crianças tentaram outras possibilidades para decompor o texto, porém decidiram que a divisão feita pelo aluno $E$ era a melhor. Ao iniciar a aula, perguntei se escrever poemas era fácil ou simples. Alguns alunos afirmaram que sim, bastava colocar palavras parecidas no fim e usar frases curtas. Depois da leitura dos três poemas e da discussão realizada em roda, para compartilhar as opiniões e análises de todos, os mesmos estudantes mudaram de opinião, dizendo que os escritores deveriam ter "[...] jogado muito rascunho fora", afirmando que escrever denota tempo e trabalho (Aluno F), aproveitei o momento e perguntei se crianças podiam escrever poemas e a resposta foi unânime: sim!

\subsubsection{Ouvir poemas - aulas 9 e 10}

Primeiro, as crianças escutaram o áudio O buraco do tatu (CAPARELLI, 2014) 30; posteriormente, Jogo de bola ${ }^{31}$ (MEIRELES, 2012, p.12). A priori, só trabalhamos com a percepção auditiva. Após algumas considerações e reflexões feitas em roda de conversa, os alunos tiveram acesso aos textos escritos. Repeti o

\footnotetext{
${ }^{30}$ Extraído dos cadernos virtuais - Olimpíada de língua portuguesa, 2014.

${ }^{31}$ Disponível em: <https://youtu.be/9jjO9fjfaZ0> Acesso em: 06/09/2016.
} 
áudio, algumas vezes, para que percebessem a entonação, fruição e postura vocal dos intérpretes. Discutimos os jogos sonoros formados pela aliteração, assonância e paronomásia.

Ao efetuar as leituras, algumas crianças tentaram imitar os intérpretes para dar ritmo aos poemas; conversamos sobre a leitura do gênero poema, explicando que ela não se caracteriza do mesmo modo que os demais gêneros. Salientei a fruição ao ler os textos. Abordei, ainda, a escolha do léxico nos poemas, como por exemplo - o uso dos adjetivos no poema de Meireles (2012) e os substantivos próprios no poema de Caparelli (2014).

No poema de Meireles (2012), "A bela bola rola:/ a bela bola do Raul. / Bola amarela, la da Arabela. / A do Raul, / azul. [...]". A força aliterativa nas consoantes /p/, /b/, /m/ se realiza para reproduzir, "[...] em sensível imagem acústica, o ruído das bolas nas mãos das crianças". No poema, a aliteração imita o jogo, há um movimento entre as vogais $e$ as consoantes de modo encadeado e sincronicamente coordenado. "[...] o leitor sente, pelos fonemas e pelo ritmo, os pulos e vaivéns das bolas coloridas" (MARTINS, 2008, p. 63).

Algumas crianças mencionaram as escolhas dos nomes próprios e das cores no poema, concluindo que a autora não os escolheu aleatoriamente, eles (tanto os nomes Arabela e Raul como as cores amarela e azul) compõem o jogo sonoro e, por isso, escolhidos para a composição textual. $\mathrm{O}$ aluno $\mathrm{K}$ tentou colocar outros nomes próprios na composição, mas a turma preferiu as escolhas da autora.

O áudio do poema, O buraco do tatu, deixou a turma encantada, em aulas posteriores, alguns alunos pediram para escutá-lo novamente. A aluna $\mathrm{H}$ quis decorar o poema. Disponibilizei para a turma os livros de Sérgio Caparelli: Poema Visual (2002), Boi da cara preta (2012); Um elefante no nariz (2000); Poesia de Bicicleta (2013). Eles se interessaram, folhearam os livros e efetuaram algumas leituras. O áudio continuou sendo ouvido, inclusive em intervalos de atividades que não fizeram parte da proposta didática. Nesses momentos, consegui perceber 0 envolvimento da turma com o gênero poema. Elas sentiam prazer em ler e ouvir o poema de Caparelli, ao ponto da aluna $\mathrm{H}$ pesquisar a biografia do autor e presentear a sala.

No decorrer da sequência, as crianças escutaram 0 áudio dos participantes da OLP (2014). Ouvir o áudio das crianças, suscitou muitos questionamentos: Quem eram aquelas crianças? Quais suas histórias de vida? Elas 
estudavam em escola pública? Moravam em São Paulo? [...] A curiosidade foi tanta, que pesquisamos (internet) quem eram aquelas crianças (não estava no planejamento da aula). Em seguida, colocamos na pasta os poemas dos participantes da olimpíada (sessenta poemas) ${ }^{32}$.

Em roda de conversa, a turma escolheu seus poemas preferidos, efetuando reflexões e algumas análises sobre os textos. Também, selecionei alguns poemas para comentá-los. Alguns alunos arriscaram destacar rimas externas, aliterações e outros recursos utilizados pelos autores mirins participantes da OLP (2014).

\subsubsection{Versos regulares - aula 11}

Curiosamente, com o texto de Caparelli (2012) em mãos, o aluno J notou que o poema, O buraco do tatu, estava alinhado no fim dos versos, posicionando o dedo em forma de régua para mostrar, perguntou se o autor tinha feito de propósito. Diante da dúvida do aluno, antecipei a aula sobre versos regulares. Aproveitei, os comentários feitos pelas crianças, para mostrar os tipos de versos (compreendidos como unidade rítmica do poema) enfatizando os versos regulares ou metrificados (GOLDSTEIN, 2006).

Apresentei à turma poemas em redondilha maior. O Buraco do tatu, (CAPARELLI, 2012) e o poema de Bagno (2011, p. 21) "E esta genial caneta/ encontra todas as rimas/ até mesmo as dificílimas/ que afligem tanto o poeta [...]". Distinguimos as sílabas gramaticais das poéticas para que as crianças percebessem a diferença. Ressaltei, ainda, que a redondilha maior é frequente na poesia popular brasileira, e está presente em muitas cantigas, como: "Atirei o pau no gato" ou em "Batatinha quando nasce", na cantiga de roda: "Como pode um peixe vivo/ viver fora da água fria/ Como poderei viver/ Sem a tua companhia" (GOLDSTEIN, 2006, p. 3738).

A redondilha menor foi exemplificada com o poema de Meireles (1983, p.31), "Da Bela Adormecida": "[...] já dormiram todos, / Pássaros celestes/ me virão cantar/ do lado do mar". E o poema de Leminski (1987, p. 122): "[...] retrato de lado/

32 Disponível em: <https://www.escrevendoofuturo.org.br/conteudo/biblioteca/nossaspublicacoes/textos-dos-finalistas/artigo/2290/texto-dos-alunos-finalistas-de-2016> Acesso em: 10 abr. 2016. 
retrato de frente/ de mim me faça/ ficar diferente" (exceção do terceiro verso, tetrassílabo).

Discorremos sobre sílaba métrica, exemplificamos com alguns poemas, dentre eles, Os Lusíadas $^{33}$, de Luís Vaz de Camões. Ao mostrar que todos os versos eram decassílabos (escolhemos alguns cantos aleatoriamente), com esquema rítmico fixo ( $A B A B A B C C$ ), com dez cantos, 1.102 estrofes e 8.816 versos, as crianças ficaram encantadas. Curiosas com a história do poema e do poeta, efetuamos uma pesquisa prévia em aula. Propusemos a separação silábica gramatical de alguns versos e a separação em sílabas poéticas para que percebessem a diferença.

A princípio, não havia colocado o poema épico no planejamento, mas no decorrer da aula, a reação ao poema de Camões rendeu muitas explanações, perguntaram se o autor estava vivo, se já havia papel naquela época, como ele conseguiu sobreviver tanto tempo longe de casa, se ele havia frequentado a escola [...]. Em suma, decidi explorar a vida do poeta e os principais fatos históricos da época, para depois voltar ao poema. Alguns meninos, no dia seguinte, trouxeram o símbolo do time de futebol Vasco da Gama (uma caravela), para saber se era a representação da viagem do herói do poema.

\subsubsection{Dicionário de rimas - aulas 12 e 13}

Em pequenos grupos (03 pessoas), as crianças montaram um dicionário de rimas. Após as explicações, observei que alguns, simplesmente, escolhiam palavras sem preocupar-se com o jogo sonoro.

Propus que olhássemos dois dicionários de rimas on-line ${ }^{34}$. Ao projetar, na lousa digital, os dicionários, nem todos conseguiram perceber a importância do som em cada rima. Foi necessário ressaltar que a rima em um poema, não é um fenômeno ortográfico, nem tampouco se limita à posição final dos versos. É importante atentar ao jogo sonoro, entendido como a repetição de sons semelhantes (ou parentesco) (GOLDSTEIN, 2006).

\footnotetext{
${ }^{33}$ Disponível em: <https://oslusiadas.org/i/> Acesso em: 13/09/2016.

${ }^{34}$ Disponível em: <http://www.dicionarioinformal.com.br/rimas/> Acesso em: 13/08/2016 e

Disponível em: < https://www.rhymit.com/pt/> Acesso em: 13/08/2016.
} 
Três grupos não conseguiram compreender, de fato, o que era para ser feito, continuaram a escolher palavras sem preocupar-se com o jogo sonoro. Por isso, decidi confeccionar o dicionário coletivo, na lousa, para que todos pudessem participar e visualizar (para assim, sanar as dúvidas). As palavras escolhidas em ordem alfabética foram aleatórias: "amor, bala, calor, dedo, eca, futum, gambá, hora, igreja, javali, leite, macaco, negro, ópera, pera, queijo, rato, sapo, tatu, uva, vazo, xarope, zebra".

A escolha de palavras limitou-se a rimar seu final. As rimas não obedeceram a ordem alfabética, então, por exemplo, na palavra de letra $A$ - amor, houve a seguinte escolha: dor, calor, horror. A única relação entre as palavras é a pronúncia final /or/. O dicionário segue essa estrutura até o fim, não houve preocupação em buscar palavras com sons semelhantes no início ou que fossem da mesma classe gramatical ou, ainda, que pertencessem à mesma família lexical. A turma observou, somente, o som semelhante no fim das palavras.

O dicionário foi confeccionado para que as crianças pensassem nas escolhas lexicais, enfatizando o som, mesmo no caso em que as palavras não se correlacionam semanticamente.

\subsubsection{Apresentação de poetas mirins - aula 14}

No decorrer das atividades, efetuamos a leitura de textos escritos por crianças de até doze anos. Com o uso dos computadores em aula, os alunos entraram na página - Jornal de Poesia ${ }^{35}$ - e puderam observar os poemas, pedi para que cada dupla escolhesse um texto, para efetuar a leitura em voz alta e comentar com a sala o motivo da escolha de seu poema.

Antes de analisar os poemas, o fato de apresentar, novamente, poemas escritos por crianças, suscitou muitos questionamentos: Quem eram aquelas crianças? Quais suas histórias de vida? Elas estudavam em escola pública? Moravam no Brasil? Eram ricas, pobres? [...]. Observamos, então, as poucas informações contidas no site. Em seguida, as duplas escolheram os poemas.

A preocupação de ser ou não de escola pública deixou-me curiosa. As crianças disseram que na escola particular, o ensino era melhor e, por isso, seria

${ }^{35}$ Disponível em: <http://www.jornaldepoesia.jor.br/infan02.html> Acesso em: 24/10/2016. 
mais comum que os escritores frequentassem escola particular na infância. Sugeri, então, que investigássemos se isso era verdade, agendei uma pesquisa para entrega. Ao entregarem a pesquisa, as crianças constataram que estudar em escola particular não é fator determinante para ser escritor. Trouxeram vários autores, como Machado de Assis, Walcyr Carrasco, Hans Cristian Andersen, dentre outros, que tiveram uma infância pobre e não estudaram em escolas particulares e, mesmo assim, se tornaram grandes escritores. Na pesquisa, elas não levaram em consideração o país de origem do escritor, nem o gênero literário produzido por ele.

No poema $A$ pintura (STORTTI, 10 anos), o aluno $P$ encontrou versos em redondilha maior: "é como a vida quando/ se misturam sentimentos/ a felicidade flui/ [...]". As crianças efetuaram a separação de sílabas poéticas em alguns poemas ${ }^{36}$, a maioria tinha versos regulares sem rimas (brancos). Após a leitura, a ênfase na aula, deu-se em analisar os textos, observando as escolhas lexicais e as escolhas gramaticais. Comentamos, ainda, sobre alguns aspectos semânticos relevantes em alguns poemas. Tratamos dos tipos de rimas.

Em relação à rima pobre, exemplifiquei com o poema, É muito complicado por ser tão simples (SOUZA, 11 anos): "Discussão que irrita, / que fere, / que grita. / Discussão que comove, / que lembra, / que move" [...]. Classe gramatical - verbo. Enfatizamos, ainda, a estrofe: "[...] Por causa de risos, / por causa de dores, / por causa de falas, / por causa de amores" [...]. Classe gramatical - substantivo. Observamos o uso da anáfora no poema - na repetição das palavras "discussão; que". E na repetição da expressão que indica causa - "por causa de".

Em relação à rima rica, utilizamos o poema, Quem sou eu (SOUZA, 11 anos): "[...] Ah, mas pensando bem, / nunca fui o que contei aqui, / acho que tudo foi um sonho, / um sonho que vivi...". - "aqui" - classe gramatical advérbio (de lugar) e "vivi" - classe gramatical verbo (primeira pessoa; indicativo; pretérito perfeito).

Percebo que, em relação à classe gramatical, identificar substantivo, adjetivo e verbo são tarefas simples, já que fazem parte do conteúdo curricular do sexto ano. Em relação aos advérbios e demais classes, houve alguns equívocos que solucionei, sem, contudo, detalhar as propriedades da classe à qual pertencem. Isso será feito posteriormente.

\footnotetext{
${ }^{36}$ Algumas usaram as palmas das mãos, outras estalaram os dedos. Ao perceber os colegas efetuando a escansão com o uso do corpo, todos aos poucos foram aderindo.
} 


\subsubsection{Atividades propostas - aulas 15 a 17}

Além da leitura e escuta dos poemas, as crianças efetuaram atividades para sistematizar as aprendizagens. Na primeira, a turma tinha que completar os espaços em branco do texto Encomenda (MEIRELES, 2012, p.30), "Desejo uma fotografia/ como esta - o senhor vê? - como esta:/ em que para sempre me ria/ com um vestido de eterna festa. [...]". Após as discussões sobre as escolhas lexicais para manter o ritmo do poema, e a execução da atividade, mostrei o texto original comparando-o com as montagens feitas em aula.

Pedi ainda, para que criassem uma nova estrofe para continuar o poema, autor anônimo (apud, ANTUNES, 2009, p. 174), "Subi a porta e fechei a escada. / Tirei minhas orações e recitei meus sapatos. / Desliguei a cama e deitei-me na luz/ Tudo porque/ Ele me deu um beijo de boa noite...". Suprimi os dois últimos versos, todos montaram outra estrofe colocando tudo ao contrário, surpreenderam-se com a continuação original do texto.

Efetuamos a leitura dos poemas: As meninas (MEIRELES, 2012, p. 16), "Arabela abria a janela. / Carolina erguia a cortina. / E Maria olhava e sorria: "Bom dia! '[...]". Rima em "abria, erguia, sorria, Maria e dia" - ditongo "ia". E o poema de Leminski (1987, p. 122): "[...] retrato de lado/ retrato de frente/ de mim me faça/ ficar diferente". Rima toante em "lạdo e faça" - vogal "a"; rima consoante em "frente e diferente", a partir da sílaba tônica "ente". ${ }^{37}$

$\mathrm{Na}$ sequência, as crianças brincaram com o jogo - Arquipélago de poemas (2014), nele escolhiam quais palavras usar para preencher os poemas. No jogo apareciam os sinais: verde, amarelo, vermelho. A cada texto parávamos para observar as escolhas dos grupos, permitindo que as crianças comentassem. Assim, as dúvidas surgidas foram sanadas, ao longo da brincadeira.

No decorrer das aulas, discutimos os tipos de rimas que se apresentavam nos versos - encadeadas, interpoladas, alternadas e emparelhadas, evidenciando 0 esquema rítmico escolhido pelo poeta.

\footnotetext{
${ }^{37}$ Alguns poemas foram explorados em mais de uma etapa.
} 


\subsubsection{Produção coletiva - aulas 18 a 21}

No decorrer das atividades, cada criança trouxe um trava-língua para a aula, brincamos com a dificuldade de expressar alguns deles, intensificando as aprendizagens sobre encontros consonantais e dígrafos, e o mesmo som formado por sílabas em ordens diferentes. Após explorar o gênero popular, oriundo da parlenda, apresentamos os poemas do livro: Travatrovas (FITIPALDI, 2013). As travatrovas da autora foram lidas e discutidas em aula, comparando-as às trovas, nascidas nos tempos das Cruzadas ${ }^{38}$.

Detectamos que, nos poemas da autora, não há a segmentação das características dos poemas em trova, ao comparar as trovas com os travatrovas, as crianças não encontraram quadras em redondilha maior. Logo, concluíram que o neologismo dado pela autora ao nome de seus poemas, não tem referência concreta às características do poema.

A turma brincou e "travou" em algumas leituras (que virou um desafio), analisamos os encontros consonantais e os dígrafos ${ }^{39}$, a turma constatou que eles são os responsáveis por "travarmos" a língua. Foram destacados os encontros consonantais /tr/; /pr/; /fr/ presentes em quase todos os poemas. "Quem se atreve, pode e prova;/ trinca o trinco, troca a tranca:/ é hora, é hora do travatrova!" (FITIPALDI, 2013, p. 07).

Após a apresentação da autora e das características dos poemas, discutimos, novamente, as rimas e seus tipos (toante; consoante; externas, internas); tratamos de assonâncias e aliterações; e, ainda, de escolha lexical. A turma leu os doze poemas que constam no livro. Elegeram os poemas: Avião, aeroplano; Se um dia me der na telha como os mais divertidos.

Propus que escrevessem um poema em grupo, tema livre (escolha dos estudantes). Ao recolher as produções, observei as principais dificuldades. Na etapa de reescrita, os grupos apresentaram seus textos aos colegas, para que opinassem e, assim, debateram as várias possibilidades de reescrita para reformular da melhor forma a versão final. Expusemos os textos no mural da sala.

\footnotetext{
${ }^{38}$ Informações extraídas do livro A trova no Espírito Santo: História e antologia. Monteiro (2011, p. 11-22).

${ }^{39}$ Sobre os conceitos de encontro consonantal e dígrafo, ver Castilho, 2016, 140-142.
} 


\subsubsection{Poeta José Paulo Paes - aula 22}

$\mathrm{Na}$ produção coletiva, detectei que alguns estudantes não conseguiram montar a estrutura do gênero ao confeccionar os textos, por isso apresentei à turma o poeta José Paulo Paes ${ }^{40}$.

Após discorrer sobre o autor, lemos os poemas: Ana e o Pernilongo; Atenção detetive; Corrida; Convite; Paraíso; Sobrenome, retirados do livro Poemas para brincar (1991). As leituras foram efetuadas concomitantes aos comentários sobre as características textuais.

Exploramos o poema Corrida "[...] De tanto correr/ um menino acabou/ por perder o fôlego/ e saiu para procurá-lo [...]" para enfatizar que os versos e estrofes não são parágrafos; além de observar a disposição do pronome oblíquo "lo" conforme prediz a norma padrão; o uso da personificação "[...] o fôlego descera/ correndo a ladeira [...]"; uso de onomatopeia "[...] dentro de um pneu/ que de tão estufado/ estourara: pum! [...]".

Os poemas, Atenção, detetive e Ana e o Pernilongo, embasaram as discussões sobre os jogos de palavras e os sons. Para explorar a intertextualidade e as escolhas gramaticais, utilizamos o poema Paraíso (alguns alunos tentaram cantar o poema, tal qual a cantiga), reiteramos os tempos e modos verbais ao interpretar o poema - as discussões pautaram-se pelos problemas oriundos do desrespeito ao meio ambiente. Ouvimos o áudio Convite (2014), discutimos o princípio de equivalência que o poeta proporciona, no balanço entre o fazer poético e as brincadeiras.

O áudio foi executado em outras aulas a pedido das crianças, tal qual o poema de Caparelli - O buraco do tatu, o áudio do poema Convite encantou a turma.

O livro Poemas para brincar, ficou na sala, disponível para a leitura até o término do ano letivo.

Escolhi José Paulo Paes para essa etapa porque gostaria de mostrar às crianças, dentre outros fatores que para escrever poemas, além da imaginação e criatividade é preciso utilizar a língua e seus recursos com personalidade. Paes em seus poemas evidencia sua criatividade com a força sonora e imagética de seus

40 Disponível em:

<http://www.prefeitura.sp.gov.br/cidade/secretarias/cultura/bibliotecas/bibliotecas_bairro/bibli otecas_a_l/josepaulopaes/index.php?p=159> Acesso em: 03/11/2016. 
textos, resultantes de escolhas lexicais; da distribuição dos caracteres na folha; das escolhas sintáticas.

\subsubsection{Produção individual - aula 23 a 26}

Após algumas leituras escolhidas na pasta, livro ou caixinha, os alunos escolheram o tema "Diversão" para produzir individualmente um poema.

Depois da primeira produção, os textos foram recolhidos. Após observações, devolvidos aos alunos. Foram feitas algumas considerações em cada texto e a reescrita dos textos foi efetuada; caso desejassem, os colegas poderiam participar e opinar sobre os textos. Depois de ouvir as opiniões dos amigos, o estudante tinha que retomar o processo de reescrita.

As produções finais foram expostas no mural da escola.

Pedi, novamente, para os alunos responderem em um pedaço de papel (sem identificar-se) a seguinte pergunta: $O$ que é poema para você? Após responderem, sem minha interferência, os papéis foram colocados em outro envelope. 


\section{ANÁLISE DO CORPUS}

Este capítulo apresenta e analisa os resultados da pesquisa, levando em consideração, sua contribuição para o campo educacional. A seleção das produções individuais e coletivas para compor o corpus do trabalho considerou o nível de aprendizagem da turma. Em aula, as crianças não foram separadas, em momento algum, nem sabiam que as atividades eram analisadas de acordo com o nível de letramento de cada um.

Em relação à aprendizagem, a turma é heterogênea. Quanto ao desenvolvimento da competência leitora e escritora, nas atividades diagnósticas (efetuadas no mês de fevereiro de 2016) e nas atividades contínuas ${ }^{41}$, eu constatei dois dados importantes:

1) Há um grupo (minoria - nove alunos) com dificuldades latentes em pontuar e paragrafar textos (diversos gêneros); dois deles escreviam, no início do ano letivo, os respectivos nomes (e outros substantivos próprios) com letra minúscula; além disso, apresentavam dificuldades em organizar os textos (coerência e coesão) em diversos gêneros (quando peço para realizar a leitura de seus textos, não entendem trechos de suas produções). Em relação à leitura, esse grupo, apresenta dificuldades, efetuando-a de modo truncado, sem respeitar a pontuação. Esse grupo, conforme os descritores avaliados na Prova Brasil, encontra-se no Nível Básico ${ }^{42}$, por possuir poucos conhecimentos sobre a língua. Esses alunos não realizam as tarefas de casa e possuem o caderno desorganizado e incompleto; para realizar as atividades em aula, necessitam de maior atenção ${ }^{43}$.

\footnotetext{
${ }^{41}$ As correções da atividade diagnóstica e das atividades contínuas pautam-se na premissa de que a coerência é intrínseca à "boa formação" do texto em relação à compreensão textual que ele provoca nos leitores, "[...] não é uma propriedade textual que possa ser localizada ou apontada no texto". E a coesão é a utilização dos elementos linguísticos, que permitem a organização sucessiva do texto estruturando-o de modo linear, com exceção do gênero poema (KOCH, 2016, p. 33).

${ }^{42}$ A Prova Brasil possui quatro níveis de aprendizagem: Avançado - alunos que superam as expectativas de aprendizado. Proficiente - alunos que estão no nível adequado de aprendizagem. Básico - alunos que estão abaixo do esperado. Insuficiente - alunos que não possuem quase nenhum aprendizado. Na turma selecionada para aplicar a proposta didática, não há estudantes no nível avançado nem no nível insuficiente (BRASIL, 2017).

43 Todos os alunos pertencentes ao Nível Básico foram encaminhados para as aulas de recuperação paralela, no contra turno, e às reuniões de tutoria para aprender a organizar o material e deixá-lo em ordem, porém, somente um aluno frequentou a recuperação. Em relação ao grupo de alunos no Nível Proficiente, alguns foram encaminhados para a tutoria para aprender a organizar-se melhor.
} 
2) Há outro grupo (maioria - dezessete alunos) que acompanha, razoavelmente bem os conteúdos propostos para o sexto ano. Contudo, alguns ainda apresentam dificuldades em pontuar (problemas recorrentes ao conteúdo do Fundamental II). A maioria apresenta coerência nas produções de escrita. Em relação à coesão - falta utilizar os recursos da língua com mais afinco (repetições de termos e de ideias são comuns; há problemas para sequenciar e amarrar as ideias/informações; nem sempre as crianças utilizam os conectores para estruturar a produção de escrita). Felizmente, ao longo do primeiro e segundo trimestre, percebi melhoras na escrita (o uso dos pronomes oblíquos; o uso de conjunções e expressões; etc.). Esse grupo, conforme os descritores avaliados na Prova Brasil, encontra-se no Nível Proficiente, por possuírem conhecimentos adequados à faixa etária e ano escolar.

Em relação ao segundo grupo, no que tange a competência textual ${ }^{44}$, sinalizo algumas diferenças entre os estudantes. Não obstante, todos estejam no Nível Proficiente - neste grupo há uma divisão: a minoria (quatro alunos) consegue utilizar os conhecimentos em gramática para perceber as relações entre as palavras utilizadas em um texto; usam o vocabulário para construir (produção de escrita) ou perceber (leitura) as estruturas textuais, as atitudes e as intenções que querem demonstrar ou que o autor construiu. São desse modo, bons leitores e produzem bons textos. Na leitura, conseguem utilizar outras habilidades linguísticas para apreender o tema e a estrutura global do texto, percebem as relações lógicas e temporais, conseguem inferir informações para saber a intenção do autor (KLEIMAN, 2007).

Porém, no segundo grupo, há alunos que possuem dificuldades de relacionar os conhecimentos de gramática para construir (produção de texto) ou perceber (leitura) as estruturas textuais. Percebo que, em textos narrativos (contos de fada, contos maravilhosos, história em quadrinhos etc.) o entendimento textual ocorre com mais facilidade, quando comparado aos textos da esfera jornalística (notícias, reportagens) e aos textos informativos (divulgação científica). Em textos literários mais elaborados (poemas, crônicas, contos de ficção ou aventura), surgem dificuldades de inferir ou relacionar as informações. Na leitura, conseguem utilizar outras habilidades linguísticas para apreender o tema e a estrutura global do texto (a

${ }^{44}$ Para os conceitos de competência textual, cf. Koch, 2004. 
depender do gênero), percebem as relações lógicas e temporais, conseguem inferir informações para saber a intenção do autor (a depender da estrutura do texto). Estes alunos realizam quase todas as atividades, mas, em alguns momentos, precisam de maior atenção, caso contrário, deixam de realizá-las (KLEIMAN, 2007).

As produções coletivas e as demais produções individuais para a análise do corpus foram selecionadas conforme o nível de conhecimento do estudante. Dessa forma, selecionei duas produções textuais coletivas e duas produções individuais - uma do nível proficiente e uma do nível básico - para analisar os recursos empregados pelos estudantes.

\subsection{O QUE É POEMA PARA VOCÊ?}

Antes de iniciar a proposta didática, as crianças responderam a seguinte pergunta: "O que é poema para você?" Colocaram suas respostas em um envelope, que foi aberto somente, no término da proposta didática. As respostas centraram-se em quatro categorias (estavam presentes em aula vinte e quatro crianças):

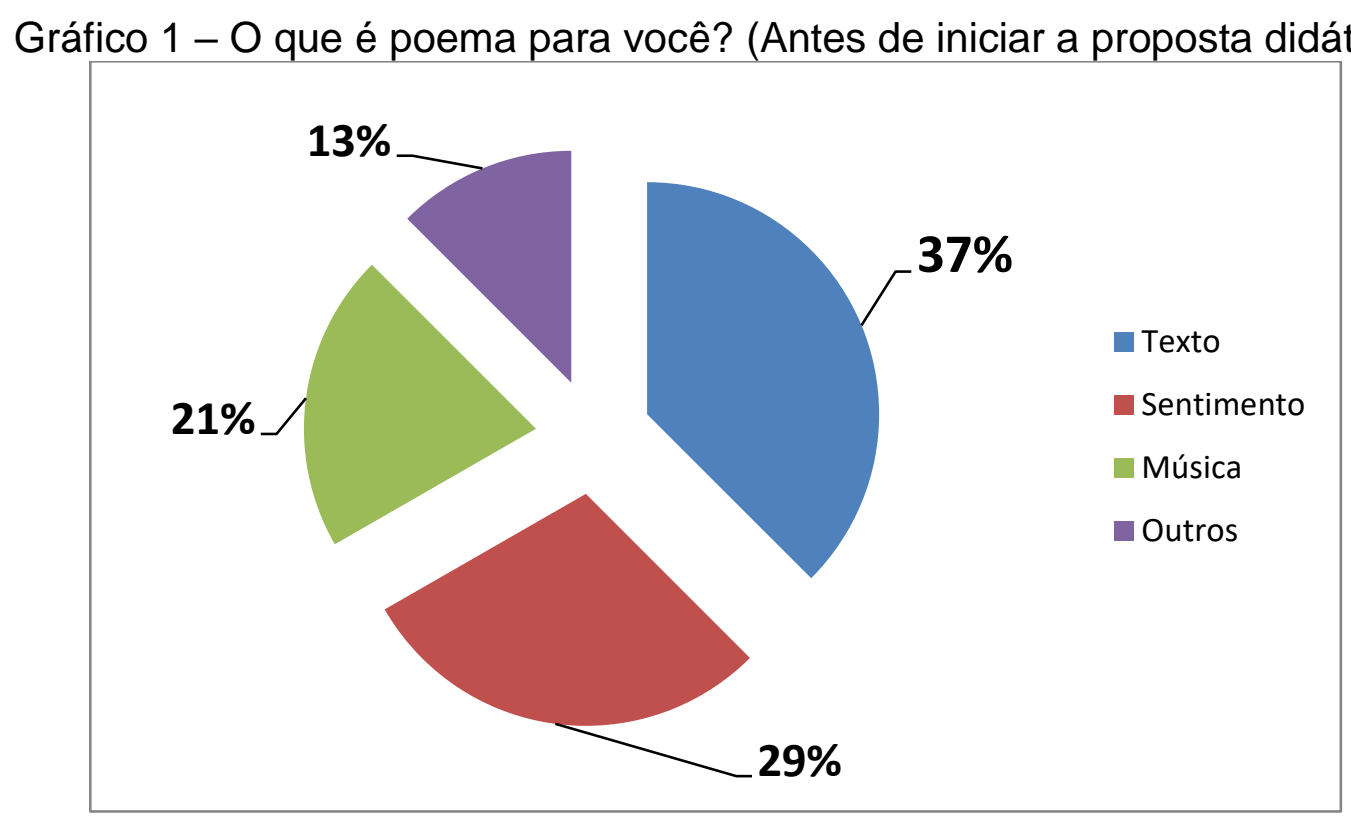

Fonte: Elaborado pela autora 
De modo geral, as crianças responderam que poema (algumas escreveram poesia) eram: Texto; Música; Sentimento ${ }^{45}$. Temos três respostas que fogem a essas categorias (inseridas no campo - Outros - 13\%): a primeira - "Eu penso que poesia é quando uma pessoa está inspirada, para mim poesia sem inspiração não é poesia". A segunda - "Algo que vem da alma, do espírito". E a terceiro, "Inspiração". Optei por colocar na categoria 'Outros', pois as respostas centram-se no plano metafísico. A generalização nas respostas evidencia que o termo "inspiração" (na primeira e terceira respostas) e o termo "algo" (na segunda resposta) possibilitam muitas variantes.

A categoria Texto foi escolhida por 37\% (9 alunos). Destes, três alunos citaram o nome de escritores - o primeiro mencionou a poetisa Cecília Meireles e o poeta Vinicius de Moraes - citou o poema Borboletas e Pedra no caminho ${ }^{46}$ (atribuiu a autoria a Vinicius de Moraes). O segundo escreveu que se lembrava do poema Borboletas de Vinicius de Moraes. O terceiro aluno respondeu: "Poema e poesia são textos com palavras complicadas de entender, mesmo assim é muito bonito e tenho muita inspiração em Carlos Drummond de Andrade, pois é muito bonito o significado das palavras dele". A referência a esses autores, provavelmente, ocorreu por causa dos projetos executados no Fundamental I.

Ainda, na categoria Texto, alguns associaram poema ao tamanho do texto, afirmaram que poema são textos curtos, outros disseram que além de curtos, eles rimam. Há, ainda, alunos que responderam ser textos que retratam sentimentos - alguns afirmaram ser sentimentos tristes, outros escreveram que eram somente de amor, poucos escreveram que se trata de um texto que retrata vários sentimentos. Um aluno escreveu que poema são textos que expressam "[...] pensamentos, comentários de um determinado assunto". Ainda, na categoria Texto, o último aluno escreveu "vários textos" que expressam a imaginação.

Há pouca noção do que seja um poema (em sua especificidade), nas três categorias as respostas recaem sobre o senso comum. Em linhas gerais, as crianças sabem que poema não é "qualquer" texto. A característica, mais próxima, do gênero citada são as "rimas". A ideia de texto que expressa sentimento, pensamentos, imaginação, é uma constante. Contudo, poderia ser aplicada a outros gêneros, dado o caráter generalista das respostas.

\footnotetext{
${ }^{45}$ Denominadas categorias para estruturar a pesquisa etnográfica, cf Gil, 2008.

${ }^{46} \mathrm{O}$ aluno refere-se ao poema No meio do caminho de Carlos Drummond de Andrade.
} 
Na categoria Música (21\% - 5 alunos), alguns afirmaram que eram canções de amor, outros, que eram músicas que falam de diversos sentimentos. Música que fala sobre a saudade. Um aluno respondeu que era uma letra cantada. Dois alunos escreveram serem músicas com rimas. A última resposta: "Poesia é uma música que a pessoa canta por cantar, não serve pra nada".

Associar música ao gênero poema é uma constante do senso comum, a sonoridade rítmica de alguns textos, fortalece essa mescla, além disso, há poemas que viraram canções. Os gêneros, em alguns momentos históricos se imbricam, os trovadores são excelentes exemplos, compunham poemas para cantá-los. Contudo, há que se considerarem as especificidades de cada gênero e, neste sentido, há diferenças latentes entre os dois.

As características dos gêneros música e poema podem confundir o leitor, mas ao adentrar no gênero textual poema, percebem-se as diferenças entre esses dois mundos. Notório salientar que um poema pode migrar para o gênero musical, desde que a ele se agreguem outros elementos que ultrapassam a melodia, ritmo e harmonia, deverá ocorrer a inserção de elementos pertencentes ao gênero musical como a melodia, a duração, a densidade, o timbre, a intensidade e a altura. A música utiliza técnicas para sons (e silêncios) estruturando palavras (letras) a um conjunto sonoro provocado por terceiros (instrumentos diversos), enquanto o poema tem como matéria prima a palavra para compor sua estrutura rítmica: nela centramse os jogos sonoros (MONTANARI, 2001).

$\mathrm{Na}$ última categoria, Sentimento (29 - 7 alunos), este ganha status de algo palpável, tem-se a materialização das emoções e sensações. As afirmações são muito parecidas: poesia é amor, romantismo, paixão, alegria, tristeza. Destaco duas respostas: a primeira, "Poesia pra mim é quando a pessoa está apaixonada". A segunda: "Lembro-me dos sentimentos que uma pessoa pode ter em determinados momentos". Ambas materializam o gênero em emoções humanas.

Relacionar o gênero a sentimentos e emoções, aspecto presente em $83 \%$ das respostas, corrobora com a afirmação de que "[...] misturar sentimentos com letras [...] cria poesia". As emoções e sentimentos seriam "a inspiração (guias) para a escrita do gênero", contudo, não é possível reduzir o poema a um texto que, somente, tem a função de expressar sentimentos (OLP, 2014, p. 01) ${ }^{47}$.

${ }^{47}$ OLP - Olimpíada de Língua Portuguesa - caderno, Cá entre nós - fascículo Poetas da 
Para escrever (independe do gênero) é necessário ter mais que inspiração ou sentimento, é preciso conhecer o gênero, suas características; conhecer a língua para utilizar e apropriar-se dos seus recursos etc. A inspiração não deve ser descartada, mas não é fator determinante de uma boa escrita. $O$ contrário também pode ocorrer só o conhecimento pode não ser o suficiente. Em poesia, "o sentimento e a imagem se fundem em um tempo denso, subjetivo e histórico", e para materializar a inspiração, e/ou o sentimento é preciso utilizar técnica - "capaz de transfigurar esteticamente a inspiração e transformá-la em poesia" (BOSI, 2000, p. 09).

Ao finalizar a proposta didática, as crianças escreveram, novamente, respondendo "O que é poema para você?" Ao comparar as duas respostas (antes e depois da proposta didática), percebo que a apropriação das características do gênero é latente. Na sala, havia vinte e seis crianças. Para estruturar a pesquisa, novamente, separei as respostas em quatro categorias - Texto, Sentimento, Música e Outros. Conforme expresso no gráfico 2, abaixo:

Gráfico 2 - O que é poema para você? (Após a aplicação da proposta didática)

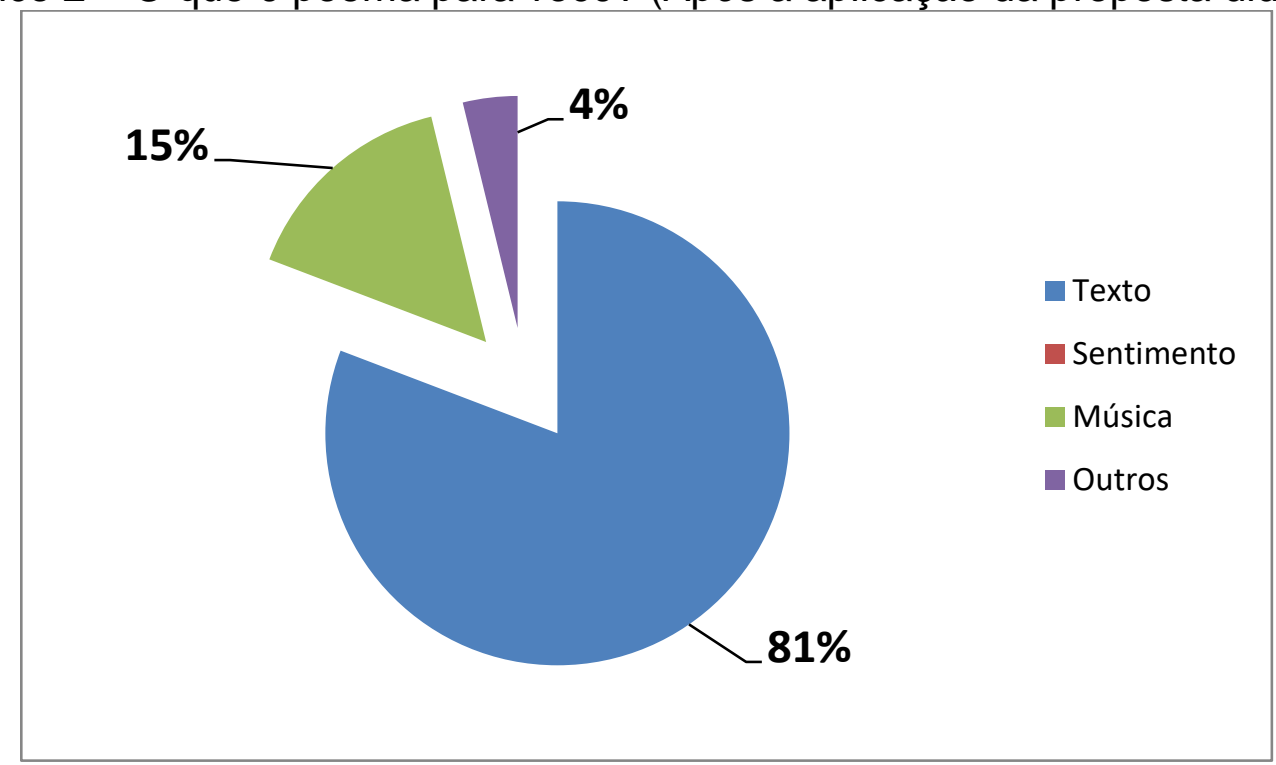

Fonte: Elaborado pela autora

Conforme o gráfico 2, é possível observar que 81\% (21 crianças) responderam que poema é um tipo de texto, ao comparar com a primeira resposta quivos/5685/olp2016-cad-pro-poe.zip> Acesso em: 07/08/2017. 
(anterior a proposta - gráfico 1), constato uma diferença de $43 \%$ para mais. Resultado significativo, pois observo a redução do equívoco (comum) de que poema é música ou sentimento.

Em relação à categoria Música (15\% - 4 crianças), uma criança disse ser "um texto cantado, que tem ritmo e verso"; outro mencionou que poema: "é rima, é poesia e é canção [...]". Outra resposta interessante é esta: "Eu vejo como música, muitos poemas que você lê, você lê cantando, é muito divertido que tem muita rima e em minha opinião pode ser qualquer tema" [Grifo nosso]. A última resposta: "Eu penso em: música, rimas, imagem e versos". Mesmo associando à música, há elementos intrínsecos ao gênero poema nas respostas, como a rima, o texto e o verso.

Nenhuma criança associou o gênero textual a sentimentos (dando a ele o status de matéria palpável, como na primeira resposta). A categoria Outros obteve somente uma resposta (4\%): "poema e poesia só nascem com muita inspiração", sem, contudo, associar o gênero às categorias: texto, música ou sentimento.

Gráfico 3 - Características do gênero conforme respostas (Após a aplicação da proposta didática)

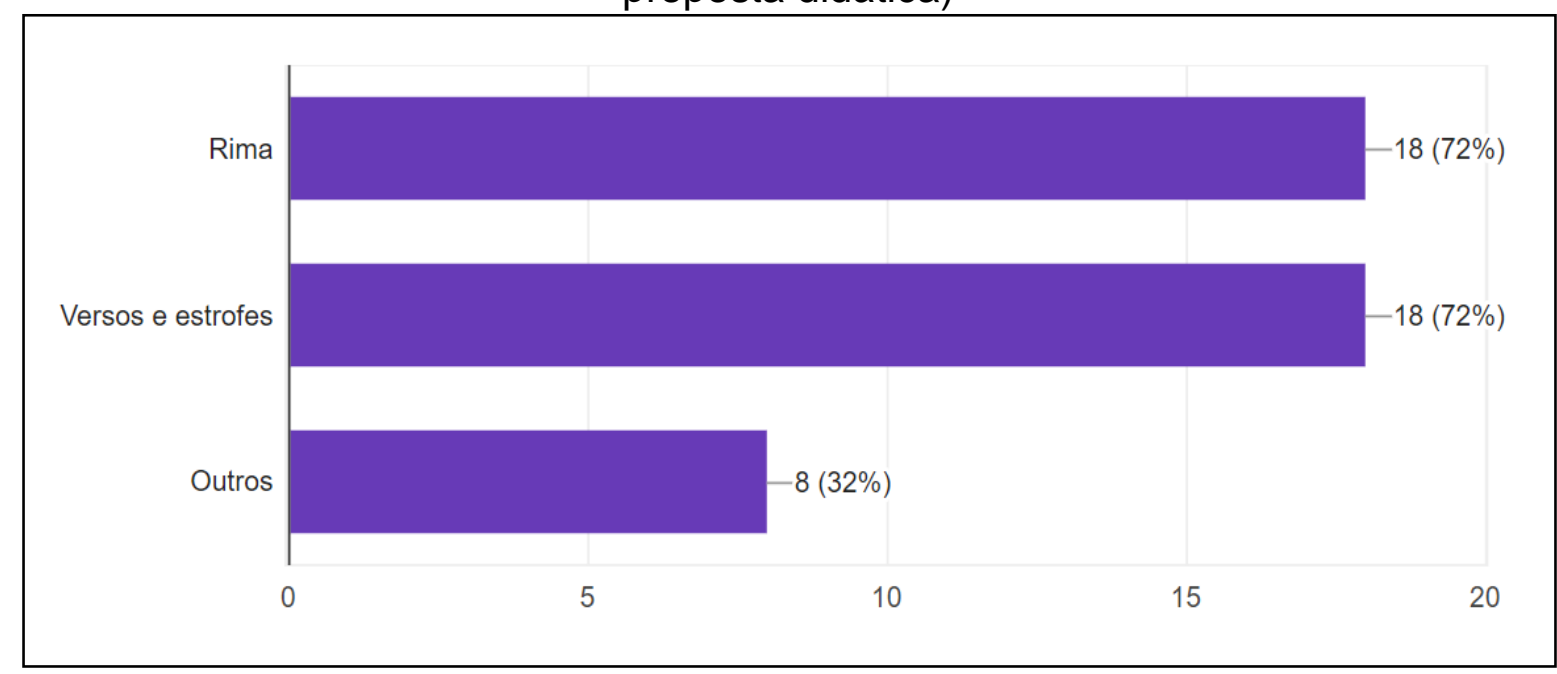

Fonte: Elaborado pela autora

$\mathrm{Na}$ categoria Texto, as características mais citadas foram: textos com rimas; textos com versos e estrofes ( $72 \%$ cada - 18 crianças), conforme expresso no gráfico 3. Algumas respostas merecem destaque, como esta: "Poema para mim é um gênero que pode ter versos, estrofes. $E$ também mostra opinião, sentimentos ou emoções do autor. É muito divertido poema porque alguns autores fazem brincadeiras. No poema pode ter rimas ou não". 
Os termos "gênero" e "gênero textual" aparecem em outras respostas, observo que as crianças respondem de acordo com as análises efetuadas no decorrer da proposta didática, apropriaram-se dos termos mencionados em aula. Ressalto que, na proposta didática, a definição de poema, bem como suas características não foi dada em forma de texto explicativo. Elas foram percebidas nas análises dos poemas e em suas respectivas leituras.

Outra resposta que corrobora com a apropriação das características do gênero textual é esta: "Eu acho que o poema transmite artes sonoras e visuais, e dentro do poema há poesia. A poesia pode ser representada por fotos, músicas, vídeos, etc.". Além desse aluno, outros mencionaram a distinção entre poema e poesia.

Ainda, de acordo com o gráfico 3, a categoria Outros centra as respostas na menção de autores. Os autores citados foram: Sérgio Caparelli; Ciça Fitipaldi e José Paulo Paes. Três respostas citaram somente Caparelli; duas Caparelli e Paes; uma Fitipaldi e duas somente Paes. Em linhas gerais, essas respostas relacionaram os autores ao aspecto lúdico de seus poemas. Um dos alunos escreveu:

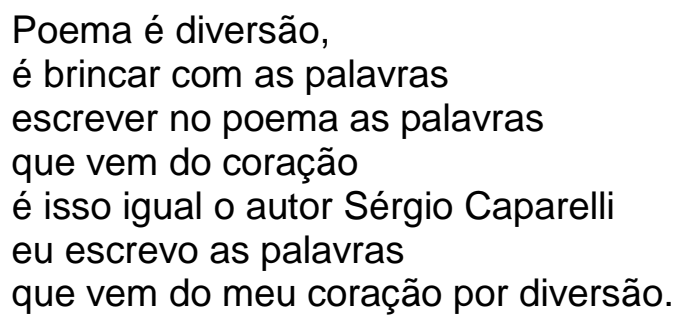

Destaco essa resposta pela tentativa de montá-la tal qual um poema, na folha ela está disposta em versos. Há, também, uma clara referência ao poema Convite (PAES, 1991) "Poesia é brincar com as palavras [...]". Poema lido e discutido em aula, seu áudio foi repetido, muitas vezes, a pedido das crianças.

Ao comparar as respostas (antes e após a proposta didática), constato que os alunos ampliaram seu repertório e conseguiram internalizar algumas características do gênero, fato que confirma que "a escrita é imbuída de agência". As atividades propostas e as intervenções efetuadas influenciaram as respostas das crianças e suas produções de escrita. A apropriação das características do gênero as mobilizou enquanto agentes - indivíduos envolvidos como protagonistas no 
processo de letramento ${ }^{48}$. Assim, a escrita tornou-se um meio de ação e, portanto, uma agência, a qual, "fornece meios pelos quais alcançamos outros através do tempo e do espaço, para compartilhar nossos pensamentos, para interagir, para influenciar e cooperar" (BAZERMAN, 2006, p. 11-12).

Deste modo, a escrita eficiente e autoral é intrínseca à agência, pois quanto mais conhecimento há da língua e das características do gênero, maior será a capacidade do estudante de refletir sobre os aspectos que o cercam, maior será a capacidade de refletir acerca dos problemas e conflitos que o envolve. Neste aspecto, a escrita é um meio de comunicação social e, não apenas, uma forma textual. O poema passou a ser uma ferramenta de agência para as crianças. Nas produções escritas e demais atividades da proposta didática, é notório o amadurecimento da turma em relação ao gênero poema (BAZERMAN, 2006, p. 19).

\section{2 ÉTHOS E ESTILO NAS ATIVIDADES DE ESCRITA}

Além da apropriação de algumas características do gênero, há textos formulados durante as atividades que ilustram o uso de estilo - compreendido aqui conforme as orientações de Possenti (2007): o estilo tem relação intrínseca com o gênero escolhido (neste caso, o poema), e com formulações que enredam um conjunto de características:

Certo jogo de sons, certo ritmo, uma ironia sutil, uma alusão, uma palavra não usual (técnica, estrangeira, popular, erudita etc.), uma forma que 'inclua' o leitor no texto, que apele para seu saber ou sua argúcia. Estilo pode ter relação com grupos, em função de suas posições, com éthos etc. (POSSENTI, 2007, p. 19).

Desse modo, estilo se aprende, inclusive na escola ${ }^{49}$. As atividades

\footnotetext{
48 Kleiman ressalta que a escola é (ou deveria ser) uma agência promotora do letramento e, assim, aproximar a escrita dos demais eventos sociais. Afirma que a escola não é a única agência que promove o letramento, mas é sem dúvida a mais importante. "Um agente social é um mobilizador dos sistemas de conhecimento pertinentes, dos recursos, das capacidades dos membros da comunidade: no caso da escola, seria um promotor das capacidades e recursos de seus alunos e suas redes comunicativas para que participem das práticas sociais de letramento, as práticas de uso da escrita situadas, das diversas instituições (KLEIMAN, 2007, p. 82-83).

${ }^{49}$ Essa posição exclui qualquer aproximação com as concepções de estilo que o coloque em correspondência com características psicológicas do autor/escritor (POSSENTI, 2007).
} 
desenvolvidas, em aula, incentivaram a criatividade e a percepção do estudante para usar as características do gênero poema em seus textos, em maior ou menor grau. E a partir das atividades de escrita, pôde-se observar a apropriação das características do gênero e particularidades que imprimem estilo aos textos.

Discini (2014) propõe que, para analisar o estilo em um texto, há que se considerarem os elementos constitutivos da língua e seus recursos. Desse modo é possível observar o modo de dizer; o modo de apresentar-se ao mundo e de ver o mundo; é possível, ainda, analisá-lo, para identificar o éthos de uma totalidade, reconstruindo o diálogo de vozes mostrado intertextualmente.

As primeiras atividades de escrita propunham completar poemas - a primeira, completar o poema de Cecília Meireles - Encomenda (2012, p.30) e a segunda, completar o poema de autor anônimo (ANTUNES, 2009, p.174). Em relação ao poema Encomenda, a maioria conseguiu completá-lo utilizando palavras com sons iguais ou semelhantes. O objetivo desta atividade foi verificar se as crianças tinham compreendido as características do gênero poema e se conseguiriam usá-las nas próprias produções.

A segunda atividade era para continuar o poema de autor anônimo (apud, ANTUNES, 2009, p. 174). Todas as crianças continuaram o poema, completando-o com uma nova estrofe, todos trocaram as funções/ações dos objetos. A brincadeira estendeu-se e, quanto mais absurdo parecesse o poema, melhor. Destaco a atividade do aluno $\mathrm{B}$ :

1. Fiz a escola, fui a lição

2. Peguei o estojo, abri o lápis

3. Tomei a janela, abri o vento

4. Joguei a chamada, respondi ao lixo no lixo

5. Cortei o rabisco, apaguei o cabelo

6. Fiz o armário, abri o trabalho

7. Li a água, bebi o livro

8. Para você que não entendeu, vou explicar

9. Troque a $1 \%$ palavra pela $1^{\circ}$ depois da vírgula

10. Então, entenderá (Aluno B).

A preocupação do aluno $B$ centra-se na brincadeira, o aspecto lúdico em sua composição fez com que seu poema fosse objeto de análise no intervalo, outras crianças (sextos anos) gostaram de ler o poema e ordená-lo (a maioria não sabia da 
atividade proposta). Mesmo reorganizando o texto, o jogo sonoro manteve-se. As rimas internas compõem a rítmica do poema e indicam o movimento (ação) - com o uso dos verbos na primeira pessoa do singular do pretérito perfeito do indicativo (peguei, tomei, joguei , cortei , apaguei , li, bebi, abrị, fíz). Ao trocar os verbos como ordena a última estrofe, o poema ficaria assim:

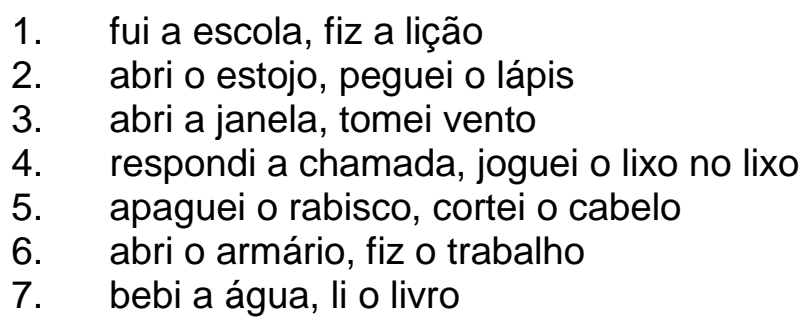

Ao ver a continuação do poema original, inspirador desta construção, as crianças surpreenderam-se, "Tudo porque/ Ele me deu um beijo de boa noite". Primeiro pela temática, segundo, por conter só dois versos significativos que reorganizam os versos precedentes, indicação fundamental para o leitor.

Ao analisar os textos produzidos pelas crianças, constato que há um modo de dizer, de contar as experiências e vivências quotidianas, o discurso não é apenas um conteúdo, ele é constituído pelos sujeitos da enunciação, permitindo ao enunciatário (em maior ou menor grau) encontrar a imagem do outro - o enunciador. Desse modo, o éthos ${ }^{50}$ estabelecido nas produções de escrita, imprime marcas linguísticas e textuais na materialidade discursiva, cria-se a imagem do enunciador via a recorrência de pistas que surgem ao longo dos textos (FIORIN, 2008).

No texto acima, o estudante formulou seu poema como um jogo, em que o leitor atua como protagonista, o diálogo estabelecido entre texto e leitor dá-se de modo dinâmico (como nas regras de um jogo). O éthos é estabelecido por meio do estilo que relaciona forma e conteúdo para fazer sentido.

O estilo empregado pelo aluno B pressupõe que o leitor efetue o recorte do texto, há assim, os "desdobramentos do sujeito da enunciação, e pressuposições de 'autor' e 'leitor'". Por conseguinte, a partir do unus (unidade integral de uma totalidade), a leitura ocorre em nemo (unidade partitiva) e ambos se relacionam ao

50 O sujeito da linguagem existe como efeito do discurso, e não fora dele. Tanto a perspectiva retórica como a semiótica assumida por Fiorin (2008) e Discini (2008) é derivada de Maingueneau (2006) o éthos é uma imagem construída pelo sujeito discursivo. 
totus (totalidade integral) (DISCINI, 2014, p. 28).

Em outras atividades, deparei-me com algumas produções feitas por iniciativa das crianças (produções em que o gênero textual pôde ser livre). Na semana de prova oficial ${ }^{51}$, fui presenteada pelo poema do aluno $\mathrm{K}$ :

\title{
Prova-provas
}

\author{
Vi a prova, travei \\ já não sei se é inglês. \\ Pode ser chinês. \\ E agora não sei \\ trocou a aula \\ e agora!? \\ Não acabei! Encalhei
}

De acordo com o aluno, o poema foi inspirado em Ciça Fitipaldi. O título faz alusão à obra da autora - em uma tentativa bem-humorada de situar o leitor sobre a temática de seu texto. Os recursos gráficos como o sublinhado no termo "não" nos versos 2 e 4; e no último verso o traço em cima do termo "acabei" realçam a força imagética do poema e dialoga com o leitor, dada a ênfase na carga negativa que as provas parecem possuir para o eu lírico. $O$ velho receio em responder provas escritas, se faz presente nos verbos - "travei"; (não) "acabei" e "encalhei". O uso da expressão "não sei" e "E agora?!" sugerem a relação desconfortável que o eu lírico tem com esse instrumento avaliativo e a escassez do tempo para a atividade. Contudo, seu texto é leve e humorado, dado o uso dos termos "inglês" e "chinês" como se fossem idiomas semelhantes, justamente, para mostrar que o eu lírico não sabia responder às questões da prova de Língua Portuguesa. O estilo, no poema, implica em uma tomada de posição que cria um efeito de singularidade, ao mesmo tempo em que reflete um éthos próprio do paradigma educação (POSSENTI, 2007).

A tentativa de imprimir a própria marca nos textos, produzindo um efeito de sentido de individualidade, é perceptível na criação de neologismos, como em "Pedrologia" em que o aluno discorre sobre as coisas que mais gosta de fazer "Assisto a filmes no celular/ com muita velocidade, sei/ que a internet viaja pelo ar/ diferente de um elefante [...]"; ou em "Tecnomagia" - "Wi-fi, internet tecnologia/ criados com inteligência/ conhecemos como 'magia'/[...] tecnologia usada no dia a

\footnotetext{
${ }^{51}$ Em São Caetano do Sul, as provas trimestrais ocorrem sempre nas duas primeiras aulas e seguem o calendário da Secretária da Educação. Neste dia, não apliquei a prova para essa turma, foi outro professor.
} 
dia/ tecnologia, magia/ Tecnomagia!!!". Neste aspecto, por meio do estilo formulado por traços recorrentes, apreensíveis na totalidade do texto, centra-se a individualidade do enunciador - "é nos seus investimentos estilísticos que o éthos do sujeito se mostra" (DISCINI, 2014, p.07).

A sistêmica recorrência da primeira pessoa, em algumas escritas, produz efeito de sentido de identidade, a exemplo: "Minha vida é igual à de muita gente/ Acordo cedo e vou direto escovar os dentes/ O tempo é curto, mal tomo café/ $E$ já tenho que dar no pé [...] Assim, quando chega o final do dia, / Já cansada e exaurida, / Fecho os olhos com alegria, / Finalizo meu dia" (aluna N). Fica evidente em alguns textos, como esse, a tentativa de se colocar nele, a criança quer fazer parte de sua escrita, por isso, representa no papel o seu éthos social (AMOSSY, 2011).

A maioria das produções carrega particularidades do mundo infantojuvenil; do universo escolar; das brincadeiras e costumes que as crianças executam no quotidiano. Os textos, muitas vezes, imprimem um éthos coletivo - funcionam como um porta-voz de um determinado grupo (AMOSSY, 2011).

Por exemplo, é possível perceber, nos textos, o grupo de estudantes que tem acesso facilmente à internet, aos jogos on-lines, aos canais de youtubers - "[...] videogame, celulares e computadores/ jogos, simuladores divertidos/ [...] aplicativos de todos os tipos/ para dar risada, sorrir/ E brincar com seus amigos [...]" (aluno Y).

Há, no entanto, outro grupo em que esses aplicativos parecem menos importantes, nestes textos, as brincadeiras coletivas em espaços abertos (maioria condomínios) são exaltadas - "Brincadeiras da minha infância/ pega-pega, escondeesconde [...] polícia e ladrão/ brincava até na escuridão/ agora só pensam em Pokémon / e eles não veem que no mundo/ tem bastante diversão" (aluno X).

Em cartazes, confeccionados para a disciplina de ciências, alguns alunos, escreveram poemas, para despertar o uso consciente da água: "Prazer! Eu sou a água/ Você já deve me conhecer/ Estou em lagos, mares e rios/ E em sua casa devo viver [...] sou sagrada e amada/ porém não preservada/ deveria ser mais cuidada/ e menos desperdiçada [...]" (aluno D). E, "[...] Água abastece o mundo, / não é um saco sem fundo. / Um dia pode acabar, / Se a gente não economizar. / [...] uma lição devemos aprender! / Sem água não podemos viver. / Portanto, comece a praticar/ $\mathrm{A}$ necessária arte de Economizar" (aluna M).

Nessas produções, o jogo sonoro alia-se à preocupação de informar o 
público alvo sobre o desperdício de água. O uso de personificação, a composição em primeira pessoa e a escolha lexical para compor o texto do aluno $D$ surpreendeu a professora de Ciências que afirmou "não esperar um trabalho caprichado deste aluno". Houve uma mudança de postura na confecção da atividade de ciências, talvez o estudante tenha se sentido à vontade para escrever, tenha compreendido o sentido da atividade e visto sentido nela. Além de utilizar seu conhecimento do gênero para além das aulas de Língua Portuguesa.

A atividade de Ciências, dentre outras, demonstra na prática o sentido de letramento, pois enquanto ação pedagógica permitiu que o estudante transportasse as estratégias de ensino do gênero poema para outros espaços. A interdisciplinaridade foi vivenciada pelos educandos em seus vários espaços culturais. Ainda que, com caráter utilitarista, a atividade foi válida para mostrar que a proposta didática ultrapassou as aulas de Língua de Portuguesa, e não findou o desejo de escrever das crianças com o seu término (SOARES, 2004).

A aluna M optou por utilizar a expressão "saco sem fundo" retirada da tradição oral, a composição dos versos em primeira pessoa do plural oscilou entre a linguagem coloquial ("a gente") e a linguagem escrita (com a supressão do pronome "nós" - devemos aprender; não podemos viver), efetivando seu recado nos dois últimos versos - terceira pessoa do singular, presente no modo imperativo: "Portanto, comece a praticar/ A necessária arte de Economizar", com ênfase no último termo escrito com letra maiúscula. Esse traço da linguagem oral, na escrita, está presente em outras produções, ele auxilia os esquemas prosódicos dos poemas e a estrutura rítmica criada pelos estudantes. As duas variedades (oral e escrita) "se dispõem num continuum, indo da oralidade para a escrituralidade, percorrendo diferentes graus de formalidade" (CASTILHO, 2016, p. 222).

\subsubsection{As produções coletivas}

Os grupos foram organizados pelas crianças: seis deles, com aproximadamente quatro crianças em cada um. A atividade em grupo teve por objetivo ativar a criatividade de cada indivíduo para integrar, em caráter de complementaridade, o conhecimento de todos. Assim, a partir da cooperação mútua, o conhecimento de cada um foi discutido e assimilado pelos outros na troca de 
opiniões e nos esclarecimentos entre os alunos para sanar dúvidas sobre as características do gênero.

O trabalho em equipe, em uma turma heterogênea, permite 0 desenvolvimento mental do estudante ao participar como protagonista do processo. Isso ocorre por que: i) o estudante é colocado em uma situação de experiência que tem interesse por si mesmo; ii) ele é desafiado a participar, sua colaboração é importante para solucionar problemas e/ou resolver conflitos; iii) o seu conhecimento e/ou suas informações são instrumentos para a descoberta de soluções; iv) soluções provisórias devem ser incentivadas e ordenadas, com a mediação mínima do professor; v) em grupo ocorre a oportunidade de colocar as soluções à prova, a fim de analisar sua eficácia (LUCKESI, 1994).

A produção coletiva foi efetuada após a apresentação da autora Ciça Fitipaldi, desse modo, os textos apresentam algumas características semelhantes, como o uso recorrente de encontros consonantais e de dígrafos para formar a estrutura sonora. A seguir, efetuo a análise de dois poemas. No caso do primeiro, Zoológico, a maioria dos integrantes do grupo está no nível proficiente; quanto ao segundo, sem título, os integrantes do grupo são pertencentes ao nível básico.

\section{Zoológico}

1. Presos "três tigres tristes"

2. Tristes ... trazem traumas

3. Tristes ... traga carne!

4. Corra longe, já que trouxe

5. Tão inquietos,

6. Tão travessos

7.É sonho vê-los tranquilos (Grupo A)

O poema faz referência ao trava-língua popular "Três tigres tristes para três pratos de trigo. Três pratos de trigo para três tigres tristes". O diálogo intertextual estabelecido no texto remete às proposições de Fiorin (2006) ${ }^{52}$ - o dialogismo é um elemento importante na construção do discurso, é um recurso linguístico-discursivo, que, dentre outras funções, estabelece a coerência e a coesão textual.

A temática do poema é exposta no primeiro verso que justifica a tristeza dos três tigres e, a partir desse acontecimento, é que o texto tem sua sequência. $O$

${ }^{52}$ cf descrito no Capítulo II, item - Caráter, essencialmente, dialógico do texto literário. 
título situa o leitor em qual lugar os tigres se encontram, sendo desse modo, peça importante à compreensão textual.

Quanto aos elementos do poema, há uma tentativa de metrificar as duas estrofes. Os versos, na primeira estrofe, oscilam entre cinco e seis sílabas poéticas (verso 1 e 4 - hexassílabos; verso 2 e 3 - pentassílabos); na segunda estrofe, os versos 5 e 6 são trissílabos, o último verso destoa dos demais com oito sílabas métricas, causando assim, uma ruptura na estrutura rítmica do texto.

As rimas não são regulares, mas estão presentes outros recursos sonoros. Nos versos 1 e 2 há a pluralização dos termos "tigres" e "traumas"; a rima toante ecoa a vogal tônica "i" nos termos "tigres" e "triste", este último repetido três vezes; note-se, também, a aliteração do grupo consonantal "tr". O uso do fonema /s/ provoca efeito sibilante, não só no fim de alguns versos, mas na composição interna dos versos 1,2,3 e 7. "Presos 'três tigres tristes'/ Tristes trazem traumas/Tristes ... traga carne! [...] É sonho vê-los tranquilos". Repete-se a aliteração do grupo consonantal 'tr", assim como de "r": "Presos 'três tigres tristes'/ Tristes ... trazem traumas/ Tristes ... traga carne! / Corra longe, já que trouxe/ [...] Tão travessos/ É sonho vê-los tranquilos".

Em relação aos sons assonantes, estes se fazem presentes de forma irregular, compondo estruturas diferentes nos versos. Nos versos 1, 2 e 3 a recorrência recai nas vogais /i/; /e/; /a/ aliadas aos encontras consonantais. No verso 4 , a presença da vogal fechada /ô/ na primeira sílaba - "corra, longe, trouxe". Nos versos 5 e 6, tem-se o som nasal "ão" na repetição da palavra "tão"; no último verso, tem-se novamente a recorrência da vogal fechada /ô/ - "sonho, los, tranquilos".

As duas estrofes no poema são semanticamente diversas, com relação ao estado de ânimo dos animais, pois na primeira a tristeza dos tigres é exaltada e, na segunda, os termos - "inquieto" e "travesso" - libertam os tigres da tristeza.

A escolha do poema, dentre os grupos, ocorreu pela atuação do grupo A os quatros alunos discutiram e participaram, realmente, de forma coletiva. Preocuparam-se em seguir as instruções para a realização do texto. As discussões, desse grupo, centraram-se em como compor a rítmica do texto.

A seguir, o segundo texto: 
Pega-pega e tropeça numa pedra

cai e levanta, é só uma criança

pega-pega, esconde-esconde

você brinca onde?

sábado e domingo no parquinho

isso é animadinho (Grupo B)

Nesse poema, há vários recursos sonoros: repetição de palavras, rimas e algumas aliterações. Os compostos "pega-pega" e "esconde-esconde" empregados duas vezes - acentuam o ritmo da brincadeira. No verso 2, ocorre rima toante interna: "levanta" / "criança"; dá-se o mesmo nos versos 3 e 4: "brinca" / "domingo"; a mesma vogal nasal é retomada na rima consoante dos versos 5 e 6 : "parquinho" / animadinho". Outra rima consoante externa situa-se nos versos 3 e 4: "esconde / aonde. $\mathrm{O}$ uso das palavras no diminutivo sugere que o local das brincadeiras (parquinho) é próprio às crianças e que são elas a ficarem animadas. Ou seja, a animação dos pequenos se transmitiria ao ambiente em que brincam.

Os verbos de ação fomentam uma leitura com movimento constante ("tropeça; cai; levanta; brinca"). Esse movimento é impulsionado, também, pela falta de pontuação, com exceção do verso 4, que dialoga com o leitor "você brinca onde?" A pergunta sugere que o leitor faça parte do mundo infantil.

Os dois poemas têm estabelecido o éthos pertencente ao mundo infantil, eles trazem elementos quotidianos para confeccionar os poemas. O primeiro recorre ao zoológico, espaço comumente, visitado por crianças; o segundo recorre às brincadeiras pertencentes ao mundo infantil. Percebe-se, nos textos, o diálogo entre o real e o imaginário; neles "[...] a voz do outro dialoga com a voz do um, de maneira que o sujeito da enunciação não é único, mas dialógico" (DISCINI, 2014, p. 223).

As escolhas lexicais e semânticas dos poemas totalizam a forma como eles são constituídos e descrevem o estilo impresso em cada texto, assim como a realização autoral dos grupos.

\subsubsection{Traços de autoria nas produções individuais}

A produção individual ocorreu na fase final da proposta didática. Os textos foram divulgados no mural da escola. Selecionei duas produções, descritas abaixo, sobre a temática "diversão". 
O primeiro texto, Diversão, foi produzido por uma aluna que está no nível proficiente. O segundo, A história da velha, por um aluno que está no nível básico.

\section{Diversão?}

1. Nesse mundo é normal ao andar,

2. um coelho de paletó encontrar.

3. Um mundo diferente, bem estranho,

4. para gente como a gente é insano.

5. E se ao contar os dedos e haver mais um,

6. em um simples zap zum?

7. E se completamente nosso dia a dia mudar?

8. Como é que vamos ficar?

9. Estamos acostumados

10. a andar de duas patas

11. Mas, e se o mundo de ponta cabeça virar?

12. E todos em acrobatas se transformar... (aluna J).

O poema atende ao tema proposto, já que cria uma relação entre diversão e imaginação. $O$ título situa a temática. Formado por uma interrogação, cria expectativa no leitor.

Quanto à disposição das rimas, destacam-se as consoantes emparelhadas AABB, na primeira estrofe: "andar/encontrar; estranho/insano". Na segunda estrofe, "um/zum; ficar/mudar", na terceira estrofe, nos verbos no infinitivo "virar/transformar". No $6^{\circ}$ verso, há o uso da onomatopeia "zap zum", resultando em jogo sonoro. Nota-se a incorporação de elementos poéticos observados em poemas lidos em aula.

Em relação à natureza das rimas, destacam-se as consoantes, identificadas em "andar" e "encontrar"; "um" e "zum"; "mudar" e "ficar"; "virar" e "transformar". No decorrer da sequência didática, as rimas consoantes foram exploradas em diversos poemas, principalmente, nas aulas 15 a 17.

Outro recurso sonoro explorado nas aulas e utilizado parcialmente pela autora é a aliteração nas consoantes $/ \mathrm{m} / \mathrm{e} / \mathrm{n} /$; observa-se, ao longo do poema, a escolha lexical com sons nasais, verso 1, "mundo e andar"; verso 2, "um e encontrar"; verso 3, "um, mundo e diferente"; verso 4, "gente, gente e insano"; verso 5, "um e contar"; verso 6, "em, um, simples, zum"; verso 7, "completamente"; verso 10 "andar"; verso 11 "mundo e ponta"; verso 12 "em e transformar".

O uso do ponto de interrogação exige do leitor uma entonação rítmica 
diferente da utilizada na primeira estrofe. Essa mudança no tom é sentida na segunda e na terceira estrofes. A terceira começa com uma afirmação no $1^{\circ}$ e $2^{\circ}$ versos, e faz uma interrogação no $3^{\circ}$ verso. A entonação interrogativa é ascendente, associada às sílabas tônicas dos verbos "mudar, ficar, virar" e da onomatopeia "zap zum" (palavras oxítonas), assim, esses versos terminam com uma elevação da voz, além de formar parcialmente rimas agudas (exceção dos versos 9 e 10). O sinal de reticências, no $4^{\circ}$ verso, imprime ao texto a sensação de continuidade, não há efetivamente a finalização do poema.

Observam-se diversos recursos sonoros. Nos versos 1 e 2 a palavra "mundo" se repete; igualmente, o artigo "um" no início do verso 2 e 3; no verso 3 , a palavra "diferente" rima com "gente"; no verso 4 há a repetição "gente/gente". Ocorre também, no verso 4, o uso da comparação "gente como a gente", aproximando leitor e eu lírico.

$\mathrm{Na}$ primeira estrofe, o texto retrata o mundo da fantasia e do distanciamento entre o real e o imaginário, o especificador ${ }^{53}$ "nesse" atua como um operador de identidade, apresentando o sintagma nominal, cujo núcleo é o substantivo "mundo". Ele atua também como um verificador, indicando que o referente é familiar para o eu lírico. Ao iniciar o verso com "Nesse mundo [...]", a autora evidencia que não é qualquer mundo, mas o mundo da imaginação, lugar em que é comum encontrar fatos inusitados: "Nesse mundo é normal ao andar, /um coelho de paletó encontrar [...]". A personificação realizada em "coelho de paletó" enfatiza o irreal sugestionado pela autora e, de certo modo, faz intertextualidade com Alice no país das maravilhas, de Lewis Carrol, em livro ou em filme.

No terceiro verso, o pronome demonstrativo é substituído pelo especificador "um", indicando que esse mundo é supostamente desconhecido pelo leitor, ao mesmo tempo em que exerce a função anafórica ${ }^{54}$, pois retoma 0 referencial "mundo" do $1^{\circ}$ verso. A diferença entre o mundo real e o imaginário, também, se consolida nos 3ำ e 4ำ versos, quando o eu lírico menciona a estranheza que o mundo fictício pode causar, adjetivando-o como "estranho", supondo que para as pessoas (aqui o eu-lírico se inclui - "[...] para gente como a gente [...]") conhecer um mundo diferente é loucura.

Os $5^{\circ}$ e $6^{\circ}$ versos retomam a primeira estrofe com a conjunção aditiva "e"

\footnotetext{
${ }^{53}$ Para os conceitos de especificadores, cf. Castilho, 2016, p. 488-501.
}

${ }^{54}$ Para os conceitos de coesão referencial ou endofórica, cf. Koch, 2004. 
55, a sentença coordenativa (funciona como um elemento de inserção enunciativa) no processo de enunciação, relaciona-se às sentenças (versos 2, 5 e 6) "[...] um coelho de paletó encontrar/ e se ao contar os dedos e haver (houver ${ }^{56}$ ) mais um/ em um simples zap zum?[...] ligando as estruturas em uma mesma hierarquia. A condicionante "se" faz uma adição hipotética do que poderia ocorrer, caso o leitor contasse o passar do tempo nos dedos, até aparecerem outros coelhos de paletó. Neste caso, o termo "coelho de paletó" é substituído pelo referente "mais um" em função anafórica. O verso 6 , "em um simples zap zum?", traz a onomatopeia e sugere velocidade, imprime agilidade à ação estabelecida no verso.

No verso 7 , há novamente o recurso aditivo "e". Neste caso, a função coordenativa correlaciona-se ao verso posterior, ocorre uma inversão no período sintático "[...] E se completamente nosso dia a dia mudar? / Como é que vamos ficar?" Acompanhado da condicionante "se" que, mais uma vez, faz uma adição hipotética do que aconteceria se o mundo (dia a dia) sofresse alterações fantasiosas.

Os versos 9 e 10 aproximam, novamente, leitor e eu lírico, há um pertencimento de grupo " (nós) estamos acostumados/ a andar de duas patas". A expressão "duas patas" indica o estado animal do homem, recoloca-nos na condição de seres pertencentes à natureza, iguala-nos aos demais animais.

Os versos 11 e 12 opõem-se à realidade estipulada nos versos 9 e 10, a sentença coordenativa adversativa - "mas" - no texto tem o papel relevante da transição, organizando uma unidade de construção de turno ${ }^{57}$, retira o leitor do mundo real (verso 9 e 10), conduzindo-o ao imaginário, identificado na interrogação que compõe o verso 11 "[...] Mas, e se o mundo de ponta cabeça virar?[...]".

Observa-se o antagonismo existente nas estrofes. Em cada uma, há sempre dois versos referentes ao mundo da fantasia e dois versos que retomam fatos reais. As estruturas sonoras do poema, constituintes das escolhas lexicais e da

55 Castilho (2016) afirma que o "e" ao iniciar uma sentença, parece ser sintaticamente inativo. Como em: "[...] E se ao contar os dedos e haver mais um [...]", para o autor é complicado admitir que as expressões possam ser sintaticamente inativas, assim, ele afirma que sentenças estruturadas como 0 verso 5 , exploram as funções sintáticas e/ou discursivas, propriedades que não se excluem, e que de algum modo a aditiva "e" exerce a ligação de atos da fala, suscitando a impressão de que há um discurso preexistente à sentença com o uso do "e".

56 Optei por manter o texto em sua fôrma original, desse modo foi conservada a forma inadequada "haver", quando o futuro do subjuntivo deveria ser "houver".

${ }^{57}$ cf Castilho, 2016. 
pontuação, indicam a percepção sonora da aluna em relação ao gênero. Mas não só, a composição textual demonstra os cuidados que a pequena poetisa teve ao compor o poema, e sua tentativa autoral, evidenciada nas escolhas sonoras, lexicais e sintáticas do texto, embora nem sempre estabelecidas de forma única na composição. No texto, observa-se singularidade "na medida em que, de algum modo, serve para chamar a atenção para uma forma um tanto peculiar de o autor estar presente no texto" (POSSENTI, 2002, p. 109).

Segue o segundo texto.

\section{História da velha}
1. A velha na caravela
2. Se machucou
3. Segurando a vela
4. Pisou na bola e escorregou
5. A vela queimou a velha
6. Que logo se curou
7. Voltou pra caravela
8. E outra aventura começou

O segundo poema, também, atende ao tema proposto. O poeta-autor imprime estilo ao texto por meio do humor. O termo "velha" atua de modo irônico com intenção sarcástica. Os fatos não são apresentados na ordem cronológica, desse modo, só no verso 4 é que o leitor é informado de como a velha se machucou. O elemento cômico se mostra presente em toda a estrofe.

Quanto à disposição das rimas, elas são cruzadas $A B A B$, na primeira estrofe: "caravela/ machucou; vela/escorregou". Na segunda estrofe, "velha/curou; caravela/começou". Nas duas estrofes, as rimas cruzadas ocorrem com substantivos; e com verbos no pretérito perfeito, terceira pessoa "machucou, escorregou, curou, começou".

Como recurso sonoro, destaca-se a repetição dos termos "velha, vela e caravela". Os sons externos centram-se na similitude do som do /ha/ e /la/; e na consoante / $/$ / presente em: vela; velha; caravela (versos 1, 3, 5 e 7). Nos versos 2, 4, 6 e 8 o som centra-se no ditongo - ou: "machucou, escorregou, curou, começou". O aluno faz uso da aliteração de "c"/k/ ao longo dos versos e também de assonâncias: os ecos sonoros estão em todos os versos de forma irregular. $O$ poema utiliza recursos oriundos das narrativas como os versos de ação e a 
sequência de fatos.

No segundo verso, o pronome "se" reflexivo está disposto no início do verso, contrastando com a gramática tradicional que prediz a ênclise como colocação básica dos clíticos ${ }^{58}$. O poema emprega traços da linguagem oral, que popularmente, utiliza a próclise em início de oração no lugar da ênclise. Outra marca da linguagem oral é identificada no verso 7: "Voltou pra caravela". O uso da grafia "pra" em substituição da grafia "para a" é recorrente na fala.

Os versos 7 e 8 avisam ao leitor que a aventura não terminou, ela recomeça com a velha de volta a caravela. O uso do recurso aditivo "e" correlacionase ao verso anterior "Voltou pra caravela/ E outra aventura começou". Em tom jocoso o texto dialoga com as grandes descobertas, dado o termo caravela, e a retomada de aventuras da protagonista (a velha). Há uma mescla de heroísmo e non-sense nas ações da velha. Essa composição dá o tom de humor ao poema que lembra a poesia popular - duas estrofes com quatro versos, com rimas alternadas.

Diante das construções poéticas e da narrativa que configura o texto, nota-se que há uma atitude autoral do estudante em registrar seu estilo. O princípio da autoria está presente nos procedimentos de controle interno do texto. A autoria está presente na materialidade do texto e na sua organização.

Conquanto, haja equívocos de acordo com a gramática tradicional e a apropriação parcial das características do gênero, o nosso autor-poeta insere-se "em um amplo processo de letramento acionado para a elaboração da redação e revelado por ela". O processo de letramento se dará em um continuum e o estudante conseguirá aprimorar-se já que tem um grande potencial criativo (TFOUNI et al, 2011, p. 444).

Nos dois textos, nota-se o uso dos modelos apresentados em sala de aula. A disposição das rimas, dos versos e até o uso de palavras são característicos dos autores apresentados e dos temas utilizados nas aulas. Os textos dialogam constantemente com as explicações e análises efetuadas durante a proposta.

A proposta didática de um modo geral possibilitou que a turma resgatasse conhecimentos adquiridos, anteriormente, e os expandisse. Embora o produto final seja o objeto de análise (produção textual), sua formulação só foi possível porque as crianças sistematizaram os conhecimentos adquiridos. Ao fim da proposta, elas já

${ }^{58}$ cf Castilho, 2016, p. 359-405. 
observavam de forma autônoma a regularidade do gênero (a disposição dos versos, estrofes, tipos de rimas, a sonoridade ou a ausência delas); conseguiam distinguir haicai de quadrinhas ou limeriques (e vice-versa); observavam os jogos sonoros apropriando-se inclusive de nomenclaturas; sentiram-se à vontade com a leitura dos textos. 


\section{CONSIDERAÇÕES FINAIS}

A proposta didática surgiu da necessidade exposta na Introdução: o estudante não consegue avançar na competência leitora e escritora no ensino fundamental II. Aliada a essa situação, o distanciamento com relação aos gêneros literários, sobretudo o gênero poema, também aparece como um problema a ser solucionado no texto introdutório.

Desse modo, ao delinear a proposta didática, queria que meus alunos conseguissem, de forma lúdica, de modo leve, aprender a ler poemas e incorporálos ao quotidiano. Consequentemente, a escrever, utilizando os recursos que a língua oferece, apropriando-se da língua materna como sujeitos historicamente constituídos - pertencentes a contextos sociais que ultrapassam os muros da escola ou a própria casa.

O cerne da proposta didática era apresentar o gênero poema, sem, contudo, deixar às crianças reféns dos modelos apresentados. $O$ intuito era que os estudantes tivessem a curiosidade aguçada para pesquisar, refletir, criticar e construir de forma sistêmica suas aprendizagens, como protagonistas do processo. Desse modo, procurei afastar-me da tradição retórica e de atividades filiadas às correntes tradicionais para apoiar-me na aprendizagem em espiral e nas proposições bakthinianas. Movimento esse que demandou pesquisas e estudos, e mesmo na posição docente, ao escrever a proposta, voltei à posição discente - na condição de aprender para reformular minhas práticas pedagógicas.

Aplicar a proposta didática, neste contexto, foi desafiador. Contudo, ao perceber os primeiros resultados, senti que estava no caminho certo.

A maior dificuldade em aplicar a proposta centrou-se em permitir que as crianças tivessem a vez e a voz em todas as aulas, o cuidado de intervir sem 'findar' as discussões, sem dar respostas prontas e acabadas, o cuidado em fazê-las refletir e criticar os modelos apresentados sentirem-se partícipes ativas das aulas, exigiu a reformulação da postura docente em classe.

A partir dessa nova abertura, os poemas puderam ser lidos sem discursos previamente estabelecidos, sem explicações acabadas. Talvez por isso, muitas aulas se estenderam e permitiram explorar nuances que foram além dos textos escritos. Em aulas, traçamos paralelos entre os textos, seus autores e seus 
momentos históricos, o poema foi objeto de estudo em suas várias vertentes, aliamos desse modo reflexão a apreciação.

Há que se considerar que a proposta foi o início para que os estudantes escrevam seus textos com estilo, imprimindo suas marcas, posicionando-se como donos da língua, em sentido mais amplo. É um trabalho de construção permanente, e a escola é responsável direta para que o estudante continue a aprimorar-se. 0 docente, nesse contexto, precisa ser o mediador e, para isso, abandonar exercícios fragmentados e a postura arcaica de que ensinar a língua é tão somente ensinar a gramática.

O aspecto cognitivo é importante nos bancos escolares. Nesta proposta, o poema em aula veio aliar o aspecto cognitivo ao aspecto afetivo - desenvolver a leitura pelo prazer estético, pelo prazer de sentir diversas emoções, resulta na ampliação das habilidades de leitura. As leituras compartilhadas em voz alta exigem que o leitor preste a atenção à própria leitura e a faça com desenvoltura, observando a pontuação, o léxico e as intenções do autor. A leitura silenciosa envolve a liberdade de ler conforme o ritmo individual. Em ambos os casos, os esquemas mentais serão estruturados para absorver e efetuar ligações entre o texto e o mundo externo, desse modo o estudante aprende a ler ...lendo. $O$ desenvolvimento da competência leitora atingirá graus de autonomia, conforme a maturação do estudante. O que permitirá de forma gradual a formação de um leitor crítico e reflexivo, mas não só, permitirá a formação de um leitor sensível e autônomo.

A escrita, também, requer que os aspectos cognitivos sejam trabalhados em aula, mas a percepção afetiva ajudará o aluno a escrever como agente em desenvolvimento. Atribuir sentido à escrita e valorizá-la como um ato social é importante para que a criança escreva com prazer e vontade. O desenvolvimento da competência escritora alcança graus de autonomia, de acordo com a apropriação das características do gênero e dos recursos linguísticos. Os exemplos apresentados, em aula, serão substituídos por outros, decorrentes das leituras autônomas.

O docente de Língua Portuguesa é, assim, responsável direto por assegurar o letramento constante da criança e auxiliá-la a produzir suas escritas com indícios de autoria, perfeitamente possíveis de serem atingidos em aula, conforme ilustram as análises efetuadas. 
Não obstante, creio que a proposta aplicada não deva ser estanque, mas, ao contrário, estar aberta a reformulações, dadas as especificidades de cada lugar e de cada sala de aula. A heterogeneidade da turma é que determinará os rumos do projeto, assim como a verificação, no final, sobre terem ou não sido atingidos os objetivos.

Acredito que, de modo geral, neste caso, foram atingidos os objetivos propostos, haja vista que conseguiu despertar o interesse dos estudantes pelo gênero, assim como aprofundar de modo proficiente os conhecimentos sobre a língua materna. No que tange aos aspectos de leitura, a aplicação didática possibilitou aos estudantes realizar leituras plurais dos diversos textos apresentados e realizar, ainda, arguições importantes sobre os tipos de leitura. Sobre a escrita de poemas viabilizou importantes instrumentos para que os estudantes pudessem, de forma autônoma, produzir suas escritas. Para isso, buscou aguçar a curiosidade e despertar o senso estético mediante as atividades lúdicas e criativas.

Ter definido, desde o princípio, o público alvo das produções causou impacto positivo na postura das crianças. Elas se preocuparam, o tempo todo, em escrever e reescrever, pois queriam causar boa impressão aos seus futuros leitores. Fizeram propaganda do mural, na escola, para que os colegas lessem seus textos. A produção final, para a maioria dos alunos, teve sentido e objetivo: a exposição no mural da escola, para a aprovação de colegas de outras salas.

Menciono, ainda, que a postura da turma em relação às aulas mudou. Ao fim da proposta, havia uma turma mais interessada e menos dispersa, os estudantes estavam ousando mais em suas escritas (poemas ou não); sentiam-se mais confiantes e percebi, ainda, o estreitamento nas nossas relações. Aproximei-me da turma, senti-me mais à vontade para mostrar alguns textos, comentá-los e lê-los e, percebo, que essa atitude foi recíproca. No início, tinha alunos menos interessados na aula e menos participativos. No decorrer das atividades, alguns alunos se aproximaram, passaram a opinar, pedir para ler. De um modo geral, todos nós nos aproximamos. 


\section{REFERÊNCIAS}

ADAM, Jean-Michel. A Linguística Textual - Introdução à análise textual dos discursos. São Paulo: Cortez Editora, 2011.

AMOSSY, Ruth (Org.). Imagens de Si no Discurso: a construção do ethos. 2ed. São Paulo: Contexto, 2011.

ANTUNES, Irandé. Língua, texto e ensino: outra escola possível. São Paulo: Parábola, 2009, p.30-45.

BAKHTIN, Mikhail. Os gêneros do discurso. Org., Trad., posfácio e notas Paulo Bezerra. Notas da edição russa Serguei Botcharov. São Paulo: Editora 34, 2016.

BAKHTIN, Mikhail; VOLOSHINOV, Valentin Nikolaevich. Discurso na vida e discurso na arte [1926]. Tradução para fins didáticos de Carlos Alberto Faraco e Cristovão Tezza. s.d., 1976, p. 1-16.

BARBOSA, Jacqueline Peixoto; ROVAI, Célia Fagundes. Gêneros do discurso na escola: rediscutindo princípios e práticas. São Paulo: FTD, 2012, p. 08-61.

BARROS, Diana Luz Pessoa de. Dialogismo, polifonia e enunciação. In: FIORIN José Luiz. (Org). Dialogismo, polifonia, intertextualidade. São Paulo: Editora da USP, 2003. p. 01-10.

BAZERMAN, Charles. Gênero, agência e escrita. São Paulo: Cortez, 2006.

BELINTANE, Claudemir. Oralidade e alfabetização: uma nova abordagem da alfabetização e do letramento. São Paulo: Cortez, 2013.

BERENBLUM, Andréia; PAIVA, Jane. Por uma política de formação de leitores. Secretaria de educação básica. Brasília: Ministério da Educação, 2009.

BORDINI, Maria da Glória. Poesia infantil e transitoriedade do leitor criança. Revista USP, n. 14, dez, 2008. Disponível em:

<http://www.revistas.usp.br/viaatlantica/article/view/50377> Acesso em: 29 set. 2016.

BOSI, Alfredo. O ser e o tempo da poesia. 8ed. São Paulo: Companhia das letras, 2000.

BRAGATTO FILHO, Paulo. Pela leitura literária na escola de 1ํo grau. São Paulo: Editora Ática, 1995.

BRAIT, Beth. Bakhtin: conceitos-chave. São Paulo: Contexto, 2005, 75-90.

BRASIL. Dados disponíveis para consulta IDEB 2015. (08/09/2016). Disponível em: $<$ http://portal.inep.gov.br/visualizar/asset_publisher/6AhJ/content/dados-do-ideb2015-ja-estao-disponiveis-para-consulta>.Acesso em: 23 set. 2016. 
. Escala de proficiência da Prova Brasil. (15/04/2017). Disponível em:

<http://provabrasil.inep.gov.br/escalas-de-proficiencia>. Acesso em: 24 set. 2017.

. LDB 9394/96. (1996). Disponível em:

<http://www.planalto.gov.br/ccivil_03/leis/L9394.htm>. Acesso em: 24 set. 2017.

. Parâmetros Curriculares Nacionais: Língua Portuguesa: primeiro e segundo ciclos / Ministério da Educação. Secretaria da Educação Fundamental. 3.ed. Brasília: A Secretaria, 1998.

. Secretaria de Educação. Parâmetros Curriculares Nacionais Ensino Médio. 3.ed. Brasília: Ministério da Educação/Secretaria de Educação, 2002.

. Secretaria de Educação. PCNEM - Parâmetros Curriculares Nacionais

Ensino Médio. Brasília: Ministério da Educação/Secretaria de Educação, 2000.

. Secretaria de Educação e Tecnológica. PCN+ Ensino Médio: Orientações Educacionais complementares aos Parâmetros Curriculares Nacionais. Linguagens, códigos e suas tecnologias. Brasília: Ministério da Educação/Secretaria de Educação e Tecnológica, 2002.

CAMPOS, Augusto de et al. Teoria da poesia concreta: textos críticos e manifestações 1950 - 1960. 4. ed. São Paulo: Ateliê Editorial, 2006.

CAMPS Anna et al. Propostas didáticas para aprender a escrever. Tradução Valério Campos. Porto Alegre: Artmed, 2006.

CÂNDIDO, Antônio. O estudo analítico do poema. São Paulo: Humanitas Publicações/ FFLCH-USP, 1996.

COLOMER, Teresa. Andar entre livros: A leitura literária na escola. Trad. Laura Sandroni. São Paulo, 2007.

CUNHA, Celso; CINTRA, Lindsay. Nova gramática do português contemporâneo. 6ed. São Paulo: Lexikon, 2016.

CUNHA, Leo. Poesia para crianças conceitos, tendências e práticas. Brasília: FNDE: Ministério da Educação, 2013.

DAHLET, Patrick. Dialogização enunciativa e paisagens do sujeito. In: BRAIT, Beth. (Org.). Bakhtin, dialogismo e construção de sentido. Campinas: Ed. Da Unicamp, 2008, p.59-84.

DE PIETRI, Émerson. O discurso da mudança do ensino de língua materna no processo de constituição da linguística brasileira. Tese de doutorado. Campinas: Instituto de Estudos da Linguagem, Unicamp, 2003.

DISCINI, Norma. O Estilo nos textos, história em quadrinhos, mídia, literatura. 2ed. São Paulo: Contexto, 2014. 
DOLZ, Joaquim; SCHNEUWLY, Bernard. Gêneros orais e escritos na escola. Campinas: São Paulo: Mercado de Letras, 2004.

DOLZ, Joaquim; NOVERRAZ, Michèle; SCHNEUWLY, Bernard. Sequências didáticas para o oral e a escrita. In: DOLZ, Joaquim; SCHNEUWLY, Bernard. Gêneros orais e escritos na escola. Campinas: São Paulo: Mercado de Letras, 2004, p. 95-128.

FIORIN, José Luiz. Introdução ao pensamento de Bakhtin. São Paulo: Ática, 2006. . Em busca de sentido: estudos discursivos. São Paulo: Contexto, 2008.

FREITAG, Bárbara. Escola, Estado e Sociedade. 4ed. São Paulo: Moraes, 1980, p. 32-36.

GEBARA, Ana Elvira. A poesia na escola: leitura e análise de poesia para crianças. São Paulo: Cortez, 2002. (Coleção aprender e ensinar com textos, v. 10).

. Por causa da redondilha...: agência e autoria em um gênero poético.

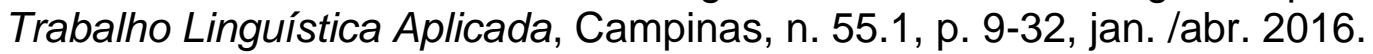

. Reflexões sobre o ensino de poesia. In: MADI, Sônia (org). Olimpíada de Língua Portuguesa, escrevendo o futuro. Na ponta do lápis. Ano VII. n.16, março, 2011.

GIL, Antônio Carlos. Como elaborar projetos de pesquisa. 4ed. São Paulo: Atlas, 2008.

GOLDSTEIN, Norma Seltzer. Gênero poético: uma proposta em espiral para o ensino fundamental II. Revista Filologia e Linguística Portuguesa. n. 8, p. 361-377, 2007.

. O poema como espaço de dialogismo: um caminho para o trabalho com poesia na escola. Revista Filologia e Linguística Portuguesa, n. 3, p.137-149, 1999.

. Versos, sons e ritmos. 13 ed. São Paulo: Ática, 2006. (Série Princípios).

GUIZZO, Antônio Rediver. Dialogismo, intertextualidade e polifonia: as múltiplas faces do discurso na literatura portuguesa. Unioeste, Cascavel, 2010.

HOUAISS, Antônio. O português no Brasil. Rio de Janeiro: Unidrade, Centro de Cultura, 1985. p. 25-26.

. Dicionário da língua portuguesa. 3ed. Rio de Janeiro: Objetiva, 2011.

INFANTE, Ulisses. Como ler poesia. In: NICOLA, José de; INFANTE, Ulisses. São Paulo: Scipione, 1993, p. 72-89.

JOLIBERT, Josette (org). Formando crianças produtoras de textos. Vol II. Porto Alegre: Artmed, 2009. 
KLEIMAN, Ângela. Oficina de leitura: teoria e prática. Campinas: Pontes, 1998. . Letramento e suas implicações para o ensino de Língua Materna. Revista Signo, Santa Cruz do Sul. v. 32, n. 53, dez. 2007, p. 1-25.

KOCH, Ingedore. Introdução à Linguística Textual. São Paulo: Martins Fontes, 2004. . O texto na linguística textual. In: BATISTA, Ronaldo de Oliveira Batista. $O$ texto e seus contextos. São Paulo: Parábola, 2016, p. 31-44.

LAHOZ, André Casa. Na Nova Economia a educação é um insumo cada vez mais importante. In: Revista Exame. Ano 34, n. 75, abril 2000, p. 173-180.

LEVIN, Samuel. Estrutura linguística em Poesia. Trad. José Paulo Paes. São Paulo: Cultrix/Edusp, 1975.

LUCKESI, Cipriano Carlos. Filosofia Da Educação. São Paulo: ed. Cortez,1994, p. 36-45.

MACEDO, Lino de; PETTY, Ana Lúcia Sícoli; PASSOS, Norimar Christe. Os jogos e o lúdico na aprendizagem escolar. Porto Alegre: Artmed, 2007.

MACHADO, Anna Rachel; CRISTÓVÃO, Vera Lúcia Lopes. A construção de modelos didáticos de gêneros: aportes e questionamentos para o ensino de gêneros. Revista Linguagem em (Dis) curso - LemD, Tubarão, v. 6, n. 3, p. 547-573, set. /dez. 2006.

MAIA, Joseane. Literatura na formação de leitores e professores. São Paulo: Paulinos, 2007.

MARTINS, Nilce Sant'Anna. Introdução à estilística. 4ed. São Paulo: Editora da Universidade de São Paulo, 2008.

MENEZES, Adélia Bezerra de. As canções do exílio. In: BOSI, Viviana et allii. $O$ poema: leitores e leituras. Ateliê Editorial, 1998, p. 105-138.

MONTANARI, Valdir. História da música: da idade da pedra à idade do rock. São Paulo: Ática, 2001. (Série Princípios).

PETIT, Michèle. Leituras: do espaço íntimo ao espaço público. Trad. Celina Olga de Souza. São Paulo: Editora 34, 2013, p. 21-63.

POSSENTI, Sírio. Ensinar estilo? Calidoscópio. vol. 5, n 1, p. 19-23, jan/abr 2007. jjun. 2002 Indícios de autoria. Perspectiva, Florianópolis, v.20, n.01, p.105-124, j an.

REZENDE, Maria Valéria. Hai-Quintal: haicais descobertos no quintal. Belo Horizonte: Autêntica, 2011. 
ROJO, Roxane. Modos de transposição dos $\mathrm{PCN}$ às práticas de sala de aula: progressão curricular e projetos. In: A prática de linguagem em sala de aula: praticando os PCN's. Roxane Rojo (org.). Campinas, SP: Mercado de Letras, 2004.

. Letramento e diversidade. In: Boletim 2004. Alfabetização, leitura e escrita. Programa 5. (2004a). Disponível em:

$<$ https://www.academia.edu/1387740/Letramento_e_diversidade_textual $>$. Acesso em: 10 dez. 2016.

Alfabetização e letramento: perspectivas linguísticas. São Paulo: Mercado de Letras, 2005.

ROJO, Roxane; CORDEIRO, Glaís Sales. Apresentação: Gêneros orais e escritos como objetos de ensino: modos de pensar, modo de fazer. In: DOLZ, Joaquim; SCHNEUWLY, Bernard. Gêneros orais e escritos na escola. Tradução de Roxane Rojo e Glaís Sales Cordeiro. Campinas, SP: Mercado das Letras, 2004. p. 7-18.

ROJO, Roxane; MOURA, Eduardo. Multiletramentos na escola. (orgs). São Paulo: Parábola Editorial, 2012.

ROSENBLATT, Louise. The reader the text the poem. The transactional theory of the literary work (1994). Disponível em:

$<$ http://tekobooks.com/download/the-reader-the-text-the-poem-the-transactionaltheory-of-the-literary-work/> Acesso em: 10 set. 2017.

ROUXEL, Roxane et al. Leitura subjetiva e ensino de literatura. São Paulo: Alameda, 2004, p. 67-87.

SANT`ANNA, Affonso Romano de. Paródia, paráfrase \& cia. São Paulo: Ática, 2003.

SANTOS, Carmi Ferraz et al. Diversidade textual: os gêneros na sala de aula. Belo Horizonte: Autêntica, 2007.

SÃO CAETANO DO SUL. Orientações curriculares de São Caetano do Sul. Secretaria da educação. SEE, 2014.

SÃO PAULO. Proposta curricular do estado de São Paulo. Secretaria da Educação, SEE: São Paulo, 2012.

SCHNEUWLY, Bernard. Gêneros e tipos de discurso: considerações psicológicas e ontogenéticas. In: DOLZ, Joaquim; SCHNEUWLY, Bernard. Gêneros orais e escritos na escola. Campinas: São Paulo: Mercado de Letras, 2004.

SOARES, Magda. Letramento e alfabetização: as muitas facetas. Revista Brasileira de Educação, abril, n. 25, 2004, p. 05-17. Disponível em:

<http://www.scielo.br/pdf/rbedu/n25/n25a01.pdf > Acesso em: 08 set. 2017. 
SOARES, Magda. Português na escola. História de uma disciplina curricular. In: BAGNO, M. (org.) Linguística da norma. São Paulo: Edições Loyola, 2002, p.155177.

SOLÉ, Isabel. A leitura exige motivação, objetivos claros e estratégias. Revista Nova Escola, agosto, 2016. Disponível em:

$<$ Https://novaescola.org.br/conteudo/304/para-isabel-sole-a-leitura-exige-motivacaoobjetivos-claros-e-estrategias> Acesso em: 08 set. 2017.

SORRENTI, Neusa. A poesia vai à escola: reflexões, comentários e dicas de atividades. 2ed. Belo Horizonte: Autêntica, 2009.

SOUZA, Gláucia de. Procurando pelo poema na sala de aula. In: CUNHA, Leo. Poesia para crianças conceitos, tendências e práticas. Brasília: FNDE: Ministério da Educação, 2013, p. 81-105.

TFOUNI, Leda et al. A dimensão político-pedagógica da "comunicação sem equívocos" frente aos desafios da escola para todos: novos lugares interpretativos para a prática docente. Linguagem \& Ensino, Pelotas, v.14, n.2, p. 427-453, jul./dez. 2011

TFOUNI, Leda Verdiani; BARTIJOTTO, Juliana. A autoria na descrição do ato infracional. Linguagem em (Dis)curso - LemD, Tubarão, SC, v. 15, n. 1, p. 137-147, jan./abr. 2015.

VYGOTSKY, Lev Semenovitch. A formação social da mente: o desenvolvimento dos processos psicológicos superiores. São Paulo: Martins Fontes, 2000.

VILLAÇA, Alcides. Escola, poesia, Drummond. IN HUBNER, R. et allii. Diário de Classe 3. Língua Portuguesa. F.D.E - SEEESP, 1994.

ZILBERMAN, Regina. A literatura infantil na escola. São Paulo: Global, 2003.

\section{REFERÊNCIAS: TEXTOS LITERÁRIOS}

ALCOFORADO, Hardy Guedes. O bailado: primeiros movimentos. São Paulo: Scipione, 1992.

ANDRADE, Carlos Drummond de. A educação do ser poético. Revista arte e educação, ano 3, n. 15, outubro, 1974, p. 16.

ANDRADE, Carlos Drummond de. Poesia completa. São Paulo: José Aguilar, 2016, p. 145.

ANTUNES, Irandé. Língua, texto e ensino: outra escola possível. São Paulo: Parábola, 2009, p.174. 
AYALA, Marcos; IGNEZ, AYALA, Maria Novais. Cultura popular no Brasil, perspectiva de análise. São Paulo; Ática, 1995.

AZEVEDO, Ricardo. Dezenove poemas desengonçados. São Paulo: Ática, 2011. . Não existe dor gostosa. São Paulo: Companhia das letrinhas, 2003.

BAGNO, Marcos. O tempo escapou do relógio e outros poemas. Curitiba: Positivo, 2011, p. 20-23.

BANDEIRA, Pedro. Palavras de encantamento: poesias. São Paulo: Moderna, Ministério da Educação, FNDE, 2009. Coleção Literatura em minha casa.

. Na rua do sabão. 3ed. São Paulo: Gaia, 2013.

. Berimbau e outros poemas. Seleção Elias José. 3ed. Rio de Janeiro: Nova Fronteira, 2006.

BELINKY, Tatiana. Quadrinhas. São Paulo: Editora 34, 2014.

CAPARELLI, Sérgio. O buraco do tatu. In: MADI, Sônia (org). Olimpíada de Língua Portuguesa, escrevendo o futuro. Cadernos Virtuais, 2014.

. 111 poemas para crianças. Porto Alegre: L\&PM, 2003.

. Boi da cara preta. Porto Alegre: L\&PM, 2012.

. Um elefante no nariz. Porto Alegre: L\&PM, 2000.

. Poesia de bicicleta. Porto Alegre: L\&PM, 2013.

CLEMENT, Rosa. Haicai para crianças. (2011). Disponível em: <www.sumauma.net>. Acesso em: 26 de jul. de 2016.

CUNHA, Leo. Cantigamente. Rio de Janeiro: Ediouro, passatempos e multimídias, 2013a.

FITIPALDI, Ciça. Travatrovas. In: MADI, Sônia (org). Olimpíada de Língua Portuguesa, escrevendo o futuro. Cadernos Virtuais, 2014.

Travatrovas. 2ed. São Paulo: Planet Books, 2013.

JAHN, Heloisa. Histórias, quadrinhas e canções. (org). São Paulo: Companhia das letras, 2004.

JOSÉ, Elias. Limeriques para pinturas. São Paulo: Noovha América, 2007. 
KIPLING, Rudyard. If. In: FIORIN, José Luiz. Introdução ao pensamento de Bakhtin. São Paulo: Ática, 2006.

LEMINSKI, Paulo. Ensaios e anseios crípticos. (Org). Alice Ruiz e Áurea Leminski. Curitiba: Pólo Editorial do Paraná, 1987, p. 122. . Haicai de Paulo Leminski. (2012). Disponível em:

<www.pensador.com.br/haicai/leminski>. Acesso em: 26 de jul. de 2016.

LISBOA, Henriqueta. O menino poeta. 2ed. São Paulo: Global, 2003. (Coleção Magias).

MARCEL, Jean. PEDERSEN, Simone Alves. Cai ou não cai? Haicais e animais. São Paulo: Avis brasilis, 2013.

MEIRELES, Cecília. Ou isto ou aquilo. $7^{\mathfrak{a}}$ ed. São Paulo: Global, 2012.

MORAES, Vinícius. A arca de Noé. São Paulo: Companhia das letras, 2004, p. 20.

PAES, José Paulo. Kipling revisitado. In: FIORIN, José Luiz. Introdução ao pensamento de Bakhtin. São Paulo: Ática, 2006.

Poemas para brincar (1991). Disponível em:

<http://wikidoamarelinho.pbworks.com/f/jose_paulo_paes.pdf> Acesso em: 06 abr. 2016.

QUINTANA, Mário. Canção de muito longe. Caderno H. São Paulo: Globo, 1987. . Sapato furado. 7ed. São Paulo: Gaudí Editorial, 2008.

REZENDE, Maria Valéria. Hai-Quintal: haicais descobertos no quintal. Belo Horizonte: Autêntica, 2011.

ROMERO, Silvio. Quadrinhas brasileiras. São Paulo: Scipione, 2016.

RUIZ, Alice S. REZENDE, Maria Valéria. Conversa de passarinhos. São Paulo: lluminuras, 2008.

TÁVORA, Viviane Veiga. Limeriques trava-línguas. São Paulo: Guia dos curiosos comunicações, 2013.

ZIRALDO. Os hai-kais do menino maluquinho. São Paulo: Melhoramentos, 2013. 


\section{ANEXO A - TERMO DE CONSENTIMENTO LIVRE E ESCLARECIDO}

Prezado (a) Estudante e Responsáveis,

Sou aluna do Programa de Mestrado Profissional em Língua Portuguesa (PROFLETRAS) da Universidade de São Paulo (USP), sob a orientação da Professora Doutora Norma Seltzer Goldstein, e realizo uma pesquisa cuja temática é: O poema no ensino fundamental II: jogos lúdicos, leitura e produção textual e, por meio deste, o convido a participar, como voluntário (a), deste estudo que tem como objetivo analisar a aplicação de proposta didática aos estudantes de sexto ano.

Todos os dados coletados serão tratados de modo confidencial, sendo utilizados nomes fictícios, para o estudante na redação do texto (dissertação) que apresentará a sistematização da pesquisa realizada.

Coloco-me a sua disposição por meio do e-mail lbattistin@usp.com, caso necessite de qualquer informação e/ou esclarecimento.

Atenciosamente,

Liliane Battistin (Mestranda)

Li as informações acima e concordo livremente, que meu filho (a) participe dessa pesquisa.

Assinatura:

RG:

Data: 
ANEXO B - TEXTOS UTILIZADOS NAS ATIVIDADES

a) Canção de muito longe (QUINTANA, 1987, p. 12)

Foi-por-cau-sa-do-bar-quei-ro

E todas as noites, sob o velho céu arqueado de bugigangas,

A mesma canção jubilosa se erguia.

A canoooavirou

Quem fez elavirar? uma voz perguntava.

Os luares extáticos...

A noite parada...

Foi por causa do barqueiro,

Que não soube remar.

b) Debussy (BANDEIRA, 2009, p. 25)

Para cá, para lá...

Para cá, para lá...

Um novelozinho de linha...

Para cá, para lá...

Para cá, para lá...

Oscila no ar pela mão de uma criança

(Vem e vai...)

Que delicadamente e quase a adormecer o balança

- Psio... -

Para cá, para lá...

Para cá e...

- O novelozinho caiu.

c) A chuva (ALCOFORADO, 1992, p. 15)

A chuva,
sobre o telhado,
executa,
gota a gota,
um leve
sapateado:
plict-plic
macio
plict-ploc
molhado.

d) O buraco do tatu, (CAPARELLI, 2014)

O tatu cava um buraco,

À procura de uma lebre,

Quando sai pra se coçar,

Já está em Porto Alegre.

O tatu cava um buraco,

E fura a terra com gana,

Quando sai pra respirar,

Já está em Copacabana.

O tatu cava um buraco 
E retira a terra aos montes, Quando sai pra beber água, Já está em Belo Horizonte.

O tatu cava um buraco Dia e noite, noite e dia, Quando sai pra descansar, Já está lá na Bahia.

O tatu cava um buraco, Tira terra, muita terra, Quando sai por falta de ar, Já está na Inglaterra. O tatu cava um buraco E some dentro do chão, Quando sai para respirar, Já está lá no Japão.

O tatu cava um buraco. Com as garras muito fortes, Quando quer se refrescar, Já está lá no Polo Norte.

O tatu cava um buraco, Um buraco muito fundo, Quando sai pra descansar, Já está no fim do mundo.

O tatu cava um buraco, Perde o fôlego, geme, sua, Quando quer voltar atrás, Leva um susto, está na Lua.

e) Jogo de bola (MEIRELES, 2012, p.12) A bela bola rola:

a bela bola do Raul.

Bola amarela, a da Arabela.

A do Raul, azul.

Rola a amarela e pula a azul.

A bola é mole, é mole e rola.

A bola é bela, é bela e pula.

É bela, rola e pula, é mole, amarela, azul.

A de Raul é de Arabela, e a de Arabela é de Raul. 
f) As meninas (MEIRELES, 2012, p. 16)

Arabela

abria a janela.

Carolina

erguia a cortina.

E Maria

olhava e sorria:

"Bom dia!"

Arabela

foi sempre a mais bela.

Carolina

a mais sábia menina.

E Maria

Apenas sorria:

"Bom dia!"

Pensaremos em cada menina que vivia naquela janela; uma que se chamava Arabela, outra que se chamou Carolina.

Mas a nossa profunda saudade é Maria, Maria, Maria,

que dizia com voz de amizade:

"Bom dia".

g) Pelos caminhos que ando um dia vai ser... (LEMINSKI, 1987, p. 122)

pelos caminhos que ando

um dia vai ser

só não sei quando

Pergunte ao pó

Cresce a vida

Cresce o tempo

Cresce tudo

E vira sempre

Esse momento

Cresce o ponto

Bem no meio

Do amor seu centro

Assim como

$\mathrm{O}$ que a gente sente

E não diz

Cresce dentro

Razão de Ser

Escrevo.

E pronto.

Escrevo porque preciso,

Preciso porque estou tonto.

Ninguém tem nada com isso.

Escrevo porque amanhece,

$E$ as estrelas lá no céu 
Lembram letras no papel,

Quando o poema me anoitece.

A aranha tece teias.

O peixe beija e morde o que vê.

Eu escrevo apenas.

Tem que ter por quê?

Retrato de lado

retrato de frente

de mim me faça

ficar diferente

Segundo consta

O mundo acabando,

Podem ficar tranquilos.

Acaba voltando

Tudo aquilo.

Reconstruam tudo

Segundo a planta dos meus versos.

Vento, eu disse como.

Nuvem, eu disse quando.

Sol, casa, rua,

Reinos, ruínas, anos,

Disse como éramos.

Amor, eu disse como.

E como era mesmo?

Sem Budismo

Poema que é bom

acaba zero a zero.

Acaba com.

Não como eu quero.

Começa sem.

Com, digamos, certo verso,

veneno de letra,

bolero, Ou menos.

Tira daqui, bota dali,

um lugar, não caminho.

Prossegue de si.

Seguro morreu de velho,

e sozinho

h) Encomenda (MEIRELES, 2012, p.30)

Desejo uma fotografia

como esta - o senhor vê? - como esta:

em que para sempre me ria

como um vestido de eterna festa.

Como tenho a testa sombria,

derrame luz na minha testa.

Deixe esta ruga, que me empresta

um certo ar de sabedoria.

Não meta fundos de floresta

nem de arbitrária fantasia...

Não... Neste espaço que ainda resta, ponha uma cadeira vazia. 
i) Autor anônimo (apud, ANTUNES, 2009, p. 174)

Subi a porta e fechei a escada.

Tirei minhas orações e recitei meus sapatos.

Desliguei a cama e deitei-me na luz

Tudo porque

Ele me deu um beijo de boa noite... 
120

ANEXO C - PRODUÇÕES DE ESCRITA - DECORRER DA PROPOSTA

2-) Suhi a porta efichei a excoda

trei minlas eracoses e reciti meus sopate

Disligivi a cama e deiti-me na luz

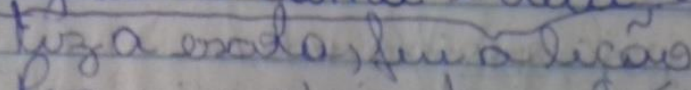

Peogue istogo, alow lo lápirs

Lomev a janelo, abru orento

Loguri a chamado respendi olixio no lixo

Corkei ig rabira Apaquei le cabeles

Euz ormário, abri strabalho

Li a águo, bula vo lirva

(1) ligal acaba aqui, ypermo né?

Paro rocê que noto entendur pou explecas Eroque a $1^{2}$ palarra pela $I^{2}$ de pois do rergulo! Entao entendero!

Prova-Prova

Ki a Prova, travei Já nãe sei se é inglés. Pode ser chinês.

t agora não sei trocou aula ce agora!?

hö acabei! Enalhu 

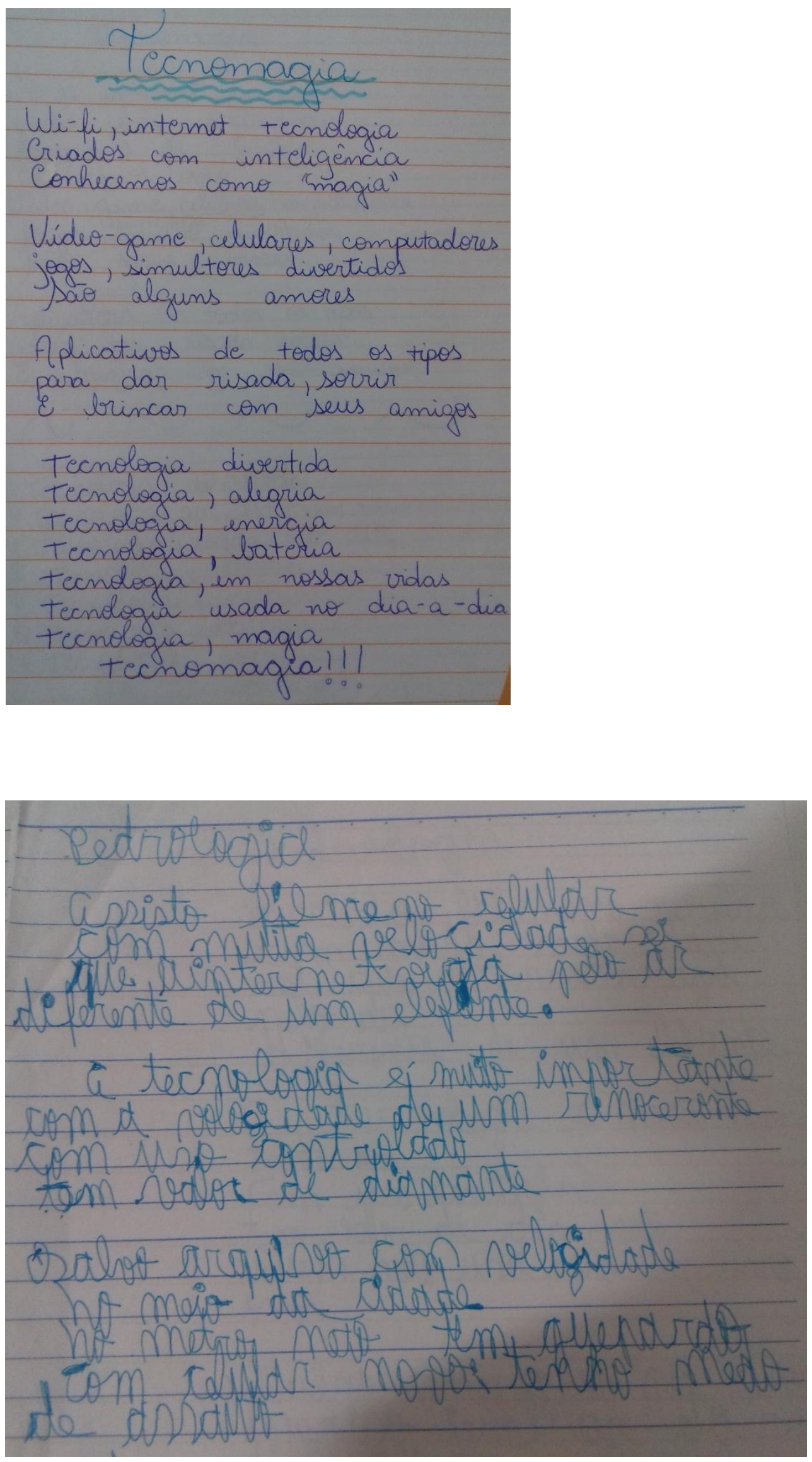

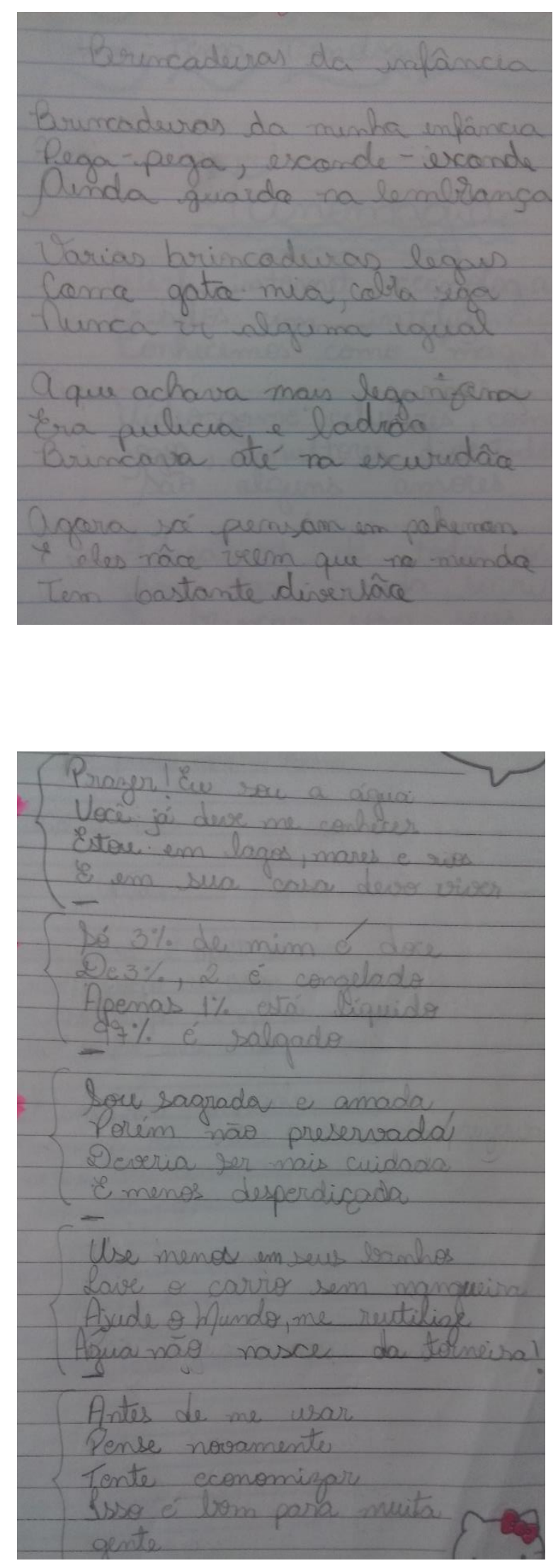
ANEXO D - PRODUÇÕES COLETIVAS
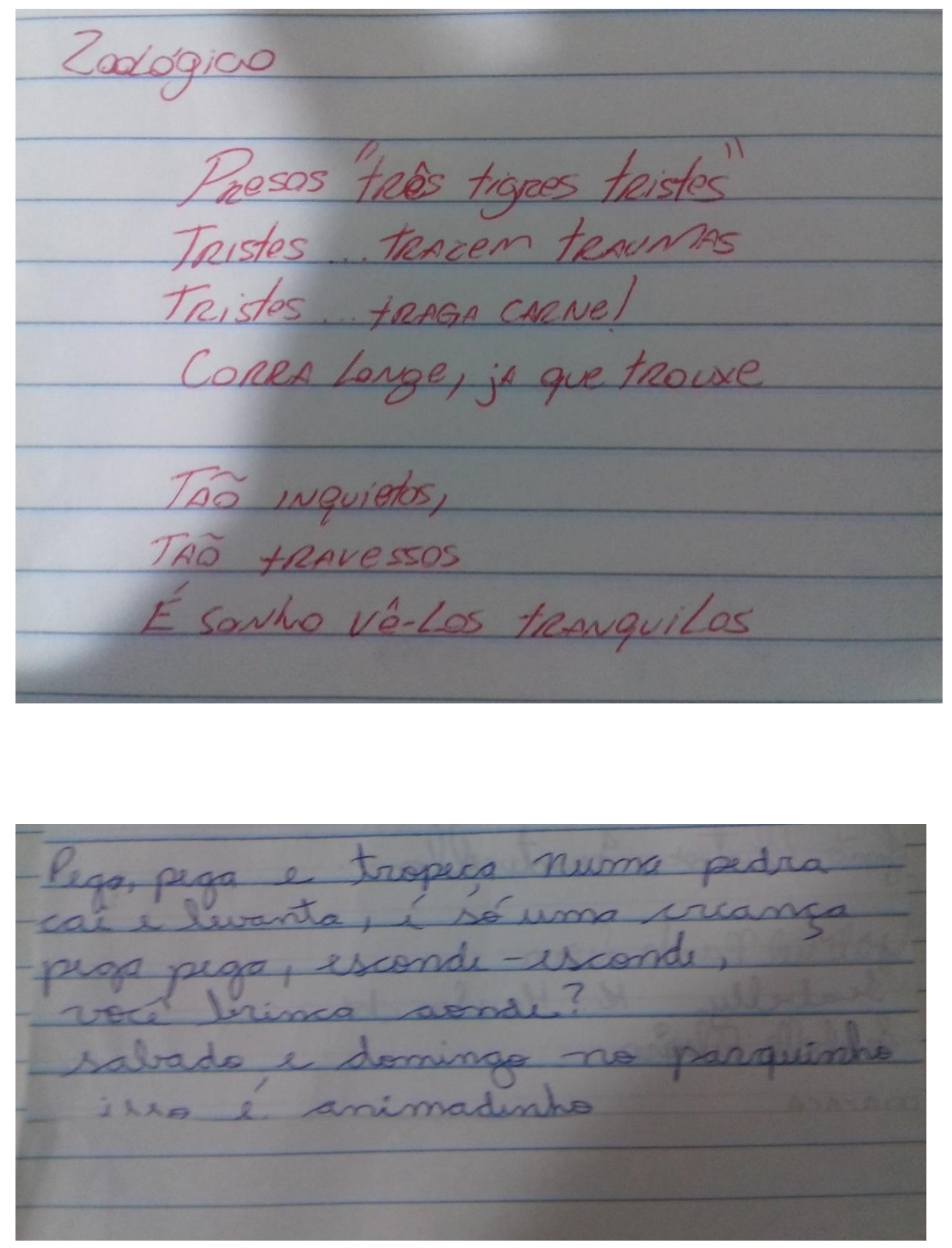
124

ANEXO E - PRODUÇÕES INDIVIDUAIS

Diversao ?

Resse mundo é normal ao andar, Um coelho de paleto encontrar, Vm mundo diferente, bem estranho, para gente como a gente $e^{\prime}$ insano.

E se ao contar os dedos e have mais com, em um simples zap zum?

$\&$ se completamente nosso dia a dia mudar?

Como í que vamos ficar?

Eitamos acostumados a andar de duas patas

Mas, e se $\theta$ mundo de ponta cakeca virar? $\varepsilon$ todos em acrobatas se transformar...

A rella na caravela

Ye maducar

Segundo a vela

eisou na bola e cuconiga

a vela quemen a vila

Que loge se curou

Volto pra caravela

E Dutra aventura comica 